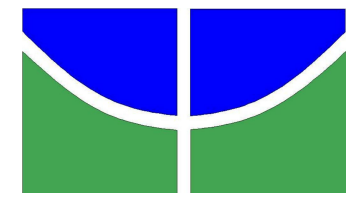

UNIVERSIDADE DE BRASÍLIA INSTITUTO DE CIÊNCIAS BIOLÓGICAS DEPARTAMENTO DE FITOPATOLOGIA PROGRAMA DE PÓS-GRADUAÇÃO EM FITOPATOLOGIA

\title{
DIVERSIDADE GENÉTICA DE POPULAÇÕES DE MYCOSPHAERELLA MUSICOLA E CARACTERIZAÇÃO DO EFETOR LYSM EM MYCOSPHAERELLA GRAMINICOLA
}

BRASÍLIA-DF 
FABIANE SILVA DAROSCI BRITO

\title{
DIVERSIDADE GENÉTICA DE POPULAÇÕES DE MYCOSPHAERELLA MUSICOLA E CARACTERIZAÇÃO DO EFETOR LYSM EM MYCOSPHAERELLA GRAMINICOLA
}

\begin{abstract}
Tese apresentada à Universidade de Brasília como requisito parcial para a obtenção de título de Doutor em Fitopatologia pelo Programa de Pós Graduação em Fitopatologia.
\end{abstract}

Orientador: Dr. Robert Neil Gerard Miller

BRASÍLIA - DF

2015 


\section{Agradecimentos}

À Coordenação de Aperfeiçoamento de Pessoal de Nível Superior (CAPES), ao Conselho Nacional de Desenvolvimento Científico e Tecnológico (CNPq) pelo apoio financeiro, tornando possível a realizaçãoo desse trabalho;

Ao professor Robert Miller, pela orientação durante o doutoramento, transmitindo os seus conhecimentos com dedicação e paciência;

Aos pesquisadores da Embrapa Vânia Azevedo, Cláudia Fortes, Alexandre Amaral pelo suporte e disponibilização de laboratórios para a execução do trabalho;

Aos pesquisadores Jason Rudd, Bart Fraaije e John Lucas do Instituto Rothamsted Research - Harpenden, Inglaterra, pela receptividade, oportunidade e apoio durante o estágio de doutorado sanduíche;

Ao colega Jansen Santos pelo apoio durante as coletas, isolamento e extração de DNA;

À Lorena Mendonça e Carlos Bragança pelo suporte nas análises dos dados de genotipagem;

Aos colegas de laboratório: Érica Santos, Gláucia Midorikawa, Camila Corrêa, Rosane Mansan, Flávia Leonel, Marco Aurélio Passos pelo apoio e compainha durante todo o curso;

Aos meus familiares, em especial aos meus pais José Brito e Fátima, por todo o incentivo durante toda a minha vida acadêmica;

Ao meu companheiro Adriano Darosci pelo apoio, incentivo, paciência e dedicação que foram fundamentais para que esse momento se concretizasse;

A todos os colegas e professores do Programa de Pós-Graduação em Fitopatologia da UnB que estiveram presentes em momentos importantes da minha formação.

Obrigada. 


\section{Sumário}

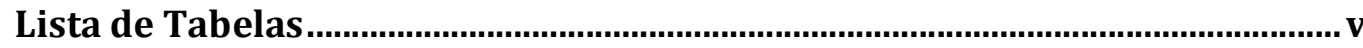

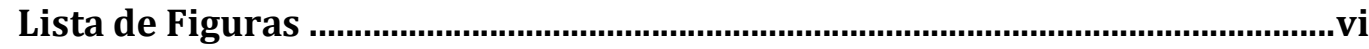

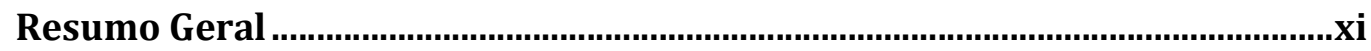

Abstract .................................................................................................................... xiii

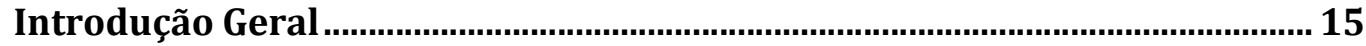

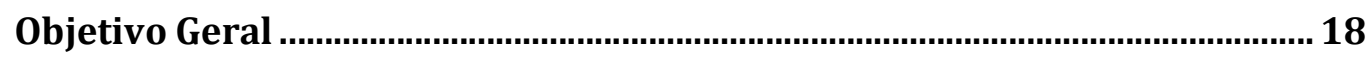

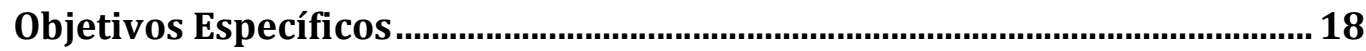



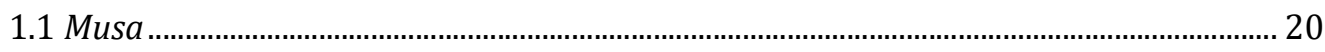

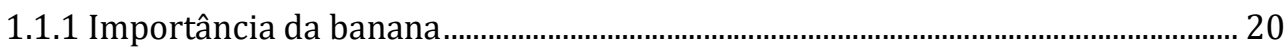

1.1.2 Classificação taxonômica de Musa .......................................................................... 21

1.1.3 Problemas fitossanitários................................................................................... 22

1.1.4 Origem da Sigatoka ......................................................................................... 23

1.2 Mycosphaerella musicola ...................................................................................... 24

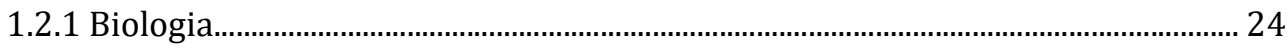

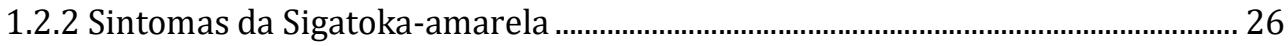

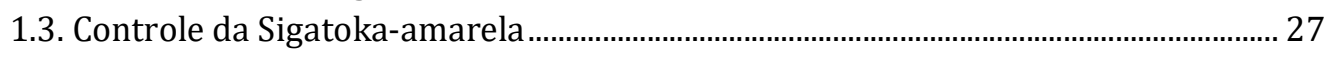

1.3.1 Fungicidas inibidores de demetilação - DMIs ..................................................... 29

1.3.2 Fatores envolvidos no desenvolvimento de resistência a fungicidas ................. 30

1.3.3 Modo de ação dos fungicidas e mecanismos de resistência em fungos.............. 31

1.4. Detecção de Mycosphaerella musicola …………......................................................... 33



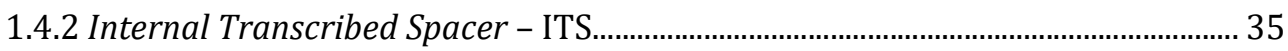



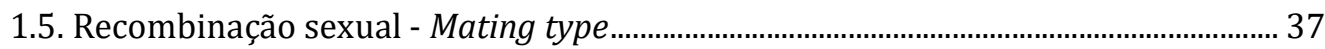



1.6.1 Análise da estrutura genética de populações...................................................... 40

1.6.2 Marcadores moleculares na análise da estrutura genética ................................... 43

1.6.3 Diversidade genética de Mycosphaerella musicola..................................................... 45

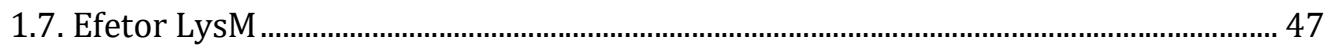

1.7.1 Mycosphaerella graminicola em trigo ...................................................................... 47

1.7.2 Infecção de Mycosphaerella graminicola no trigo.................................................... 48

1.7.3 Imunidade desencadeada por PAMPs (PTI) e efetores (ETI) ………................... 50 




1.7.5 Receptores de efetores em plantas.................................................................... 53

Capítulo 2 - Análise da diversidade genética e recombinação sexual em populações de Mycosphaerella musicola .......................................................... 55

Resumo



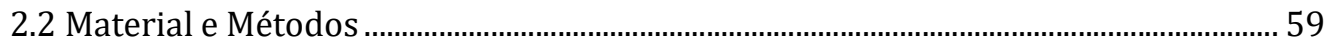

2.2.1 Coletas e isolamento de M. musicola …….............................................................. 59

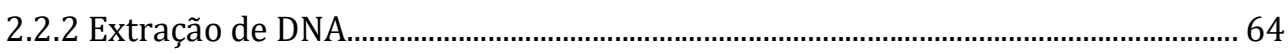

2.2.3 Identificação molecular das amostras.................................................................. 65

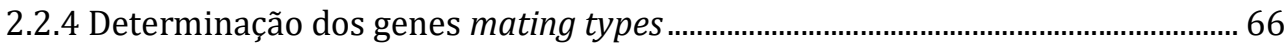

2.2.5 Identificação de haplótipos...................................................................................... 67



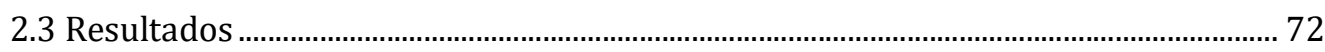

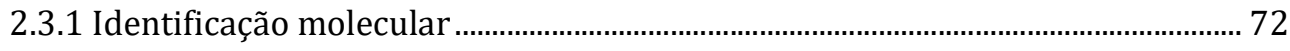

2.3.2 Sequenciamento e frequência dos genes mating types ......................................... 72

2.3.3 Diversidade genética dentro das populações............................................................ 76







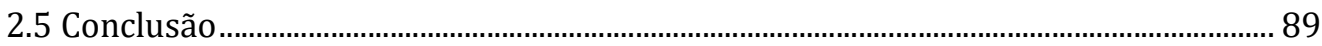

Capítulo 3. Sensibilidade de populações de Mycosphaerella musicola a

fungicidas DMIs ................................................................................................. 90

Resumo

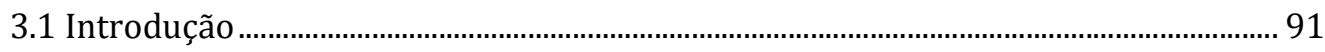

3.2 Material e Métodos ............................................................................................. 93

3.2.1 Origem e identificação dos isolados de M. musicola ……….................................... 93

3.2.2 Sensibilidade de M. musicola a fungicidas DMIs ..................................................... 94

3.2.3 Amplificação e sequenciamento de genes alvo de fungicidas .............................. 97

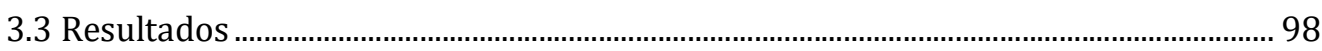

3.3.1 Sensibilidade de M. musicola a fungicidas DMIs ................................................... 98

3.3.2 Amplificação e sequenciamento de genes de proteínas alvo dos fungicidas.104

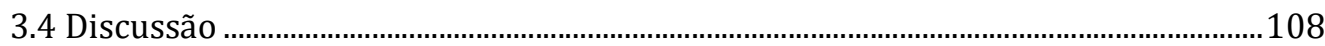



Capítulo 4. Caracterização do efetor LysM na espécie modelo Mycosphaerella graminicola ..........................................................................112



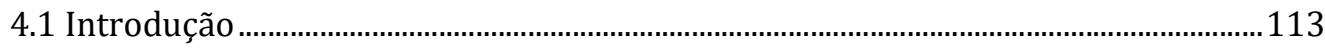




4.2.1 Amostras fúngicas e variedades de trigo …………………………………...........115

4.2.2 Resposta de cultivares de trigo ao modelo B3-GFP ............................................116

4.2.3 Colonização de M. graminicola em trigo.............................................................117

4.2.4 Sequenciamento da região 3LysM de B3-GFP.................................................118

4.2.5 - Síntese de B3-GFP mutante não funcional para o gene 3LysM .......................121

a - Clonagem dos fragmentos em Escherichia coli ......................................................121

b - Transformação de Agrobacterium tumefaciens .......................................................125

c - Transformação de M. graminicola mediada por A. tumefaciens...............................125

d. Extração do DNA genômico fúngico ..............................................................................126

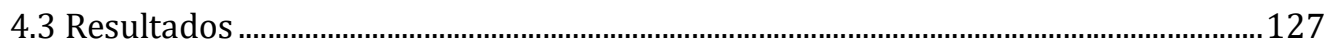

4.3.1 Resposta de cultivares de trigo ao modelo B3-GFP ..........................................127

4.3.2 Colonização de M. graminicola em trigo................................................................128

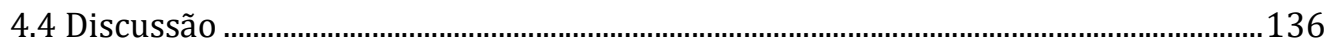



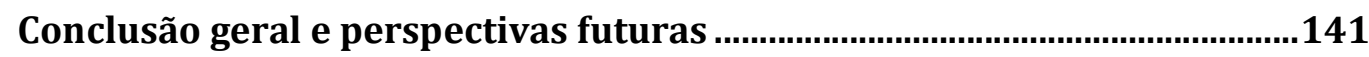



Anexo 1. Artigos publicados ..............................................................................169 


\section{Lista de Tabelas}

Tabela 1. Origem dos isolados de Mycosphaerella musicola ...................................... 61

Tabela 2. Características dos primers para as regiões ITS do rDNA, ACT, H3 e gene mating type e tamanho esperado de fragmento.

Tabela 3. Características dos 19 marcadores de microssatélites desenvolvidos para Mycosphaerella musicola utilizados.

Tabela 4. Distribuição de genes mating types e desequilíbrio de ligação em populações de Mycosphaerella musicola.

Tabela 5. Distribuição dos alelos, diversidade gênica e sumário estatístico das 13 populações de Mycosphaerella musicola.

Tabela 6. Identificação, distribuição e frequência de haplótipos nas populações de Mycosphaerella musicola. 79

Tabela 7. Variabilidade genética de Mycosphaerella musicola de acordo com AMOVA. 80

Tabela 8. Diversidade genética $\left(\mathrm{F}_{\mathrm{ST}}\right)$ em pares de populações de Mycosphaerella musicola. 81

Tabela 9. Identificação e fontes dos isolados de Mycosphaerella musicola. 94

Tabela 10. Sensibilidade a fungicidas e mutação encontrada no gene CYP51 dos isolados de Mycosphaerella musicola analisados 103 


\section{Lista de Figuras}

Figura 1. Ciclo de vida de Mycosphaerella spp em bananeira (Churchill, 2011). 25

Figura 2. Diferentes graus de desenvolvimento das lesões de Sigatoka-amarela (Cordeiro et al., 2011).

Figura 3. Mapa genético de uma unidade do rDNA em eucariotos mostrando a região ITS (ITS1 e ITS2) e as subunidades flanqueadas pela mesma. 36

Figura 4. Organização dos locos mating types de M. musicola e M. fijiensis. Sequências dissimilares (idiomorfos) são indicados com linhas brancas, e sequências idênticas por linhas pretas. Modelos de genes previstos são indicados por setas. A escala mostra o tamanho em kilobases (Arzanlou et al., 2010).......... 39

Figura 5. Modelo "zigzag" ilustrando as etapas do desenvolvimento do sistema imunológico da planta durante a infecção. Na primeira fase, as plantas detectam a população microbiana (PAMPs, diamantes vermelhos), desencadeando uma resposta de imunidade (PTI). Na segunda fase, patógenos liberam efetores que interferem com a PTI, desencadeando a susceptibilidade por efetores (ETS). Na terceira fase, um efetor (indicado na figura em vermelho, Avr) é reconhecido pelas proteínas NB-LRR, ativando a imunidade desencadeada por efetores (ETI), uma versão ampliada de PTI que muitas vezes induz a resposta de hipersensibilidade (HR). Na quarta fase, novos efetores surgem através do fluxo horizontal de genes (em azul), ajudando os patógenos a suprimir o ETI. A seleção por parte das plantas de novos alelos de proteínas NB-LRR, que podem reconhecer um dos efetores recém adquiridos, dispara novamente a ETI. Fonte: Jones \& Dangl, 2006 52

Figura 6. Distribuição geográfica dos isolados de Mycosphaerella musicola coletados em zonas produtoras de banana no Brasil. Distrito Federal e entorno: EsBio - Estação biológica; CPAC - Embrapa Cerrados; FzCa - Fazenda Canaã ; SJA - São João da Aliança; STOS - Fazenda Santos. Bahia: BJL - Bom Jesus da Lapa; TaNe - Tancredo Neves; SeLa_Sebastião Laranjeiras; ITJ - Itajuípe; BaCh - Barra do Choça. Minas Gerais: LV - Lavras. Rio Grande do Norte: IPG - Ipanguaçu; BRN - Baraúna. 60

Figura 7. Sintomas típicos de Sigatoka-amarela. A- Cultivares de banana no Distrito Federal; B- Regiões necróticas causando redução da área foliar; C- 
Lesões necróticas envoltas por halos amarelos; D- Formação de esporodóquios no centro das lesões

Figura 8. Etapas do isolamento de Mycosphaerella musicola de folhas de bananeira apresentando sintomas de Sigatoka-amarela. A, B e C- Assepsia, seleção de lesões e preparo de câmara úmida, respectivamente. D, E e F - Seleção de conídios a partir de esporodóquios no centro das lesões. G- Colônias monospóricas de M. musicola após 10 dias de crescimento 63

Figura 9. Quantificação de DNA, em gel de agarose, de colônias monospóricas de Mycosphaerella musicola coletados na Fazenda Santos - DF. Coluna 1: marcador Low DNA Mass Ladder (Invitrogen); colunas 2 a 19: 18 isolados da Fazenda Santos. 65

Figura 10. Amplificação e genotipagem dos locos SSR. A. confirmação em gel de agarose da amplificação do loco SSRMm26 em isolados representativos (Colunas 2 a 13). Colunas 1 e 14: DNA ladder 1Kb Plus da Invitrogen; B. Genotipagem para os locos SSR106 (pico verde); C. SSR22 (pico azul) sob análise através do programa GeneMapper. Eixo x: tamanho do fragmento; eixo y: intensidade da fluorescência 70

Figura 11. Produto da amplificação da região ITS do rDNA, em gel de agarose, de colônias monospóricas de Mycosphaerella musicola coletadas na Estação Biológica - UnB (Colunas 2 a 16). Coluna 1: DNA ladder $1 \mathrm{~Kb}$ da Invitrogen.......... 73

Figura 12. Produto da amplificação de parte dos genes actina (a) e histona H3 (b), em gel de agarose, de representantes de Mycosphaerella musicola das diferentes localidades (Colunas 2 a 13). Colunas 1 e 14: DNA ladder $1 \mathrm{~Kb}$ Plus da Invitrogen. 74

Figura 13. Amplificação da região mating type, em gel de agarose, do DNA de colônias monospóricas de Mycosphaerella musicola coletadas na Estação Biológica - UnB (Colunas 2 a 20). Coluna 1: DNA ladder $1 \mathrm{~Kb}$ da Invitrogen. .......... 74

Figura 14. Dendrograma baseado na distância genética (Nei, 1978) entre as 13 populações de Mycosphaerella musicola com base na análise de 19 locos SSR. (Método = UPGMA - Unweighted Pair Group Method with Arithmetic Mean).......... 83

Figura 15. Análise do agrupamento das 13 populações de Mycosphaerella musicola usando 19 locos SSR, com base no programa STRUCTURE. Cada indivíduo é representado por uma barra na figura onde $\mathrm{k}$ é o número de agrupamento $(\mathrm{k}=4)$. Isolados são ordenados pela sua probabilidade de adesão ao grupo. 84 
Figura 16. Etapas do bioensaio para a análise da sensibilidade dos isolados de Mycosphaerella musicola a fungicidas. A e B, maceração da cultura fúngica com 20 dias de crescimento. $\mathrm{C}$ e $\mathrm{D}$, preparo da suspensão dos fragmentos miceliais para distribuição em microplacas. E e F, leitura das microplacas após sete dias de incubação. 96

Figura 17. Sensibilidade de isolados de Mycosphaerella musicola aos fungicidas tebuconazol, carbendozim, azoxystrobin e epoxiconazol. 99

Figura 18. Sensibilidade de isolados de Mycosphaerella musicola à diferentes concentrações (poços das colunas de 1 a 12) de fungicidas DMIs. A, epoxiconazol e B, pyrenifoz $(1,0,4,0,16,0,064,0,0256,0,01024,0,004096,0,001638$, 0,000655, 0,000262, 0,000105mg L-1). C, tebuconazol $(10,4,1,6,0,64,0,256$, $\left.0,1024,0,04096,0,016384,0,006554,0,002621,0,001049 \mathrm{mg} \mathrm{L}^{-1}\right) . \mathrm{D}$, triadimenol $(50,20,8,3,2,1,28,0,512,0,2048,0,08192,0,032768,0,013107$, 0,005243 $\left.\mathrm{mg} \mathrm{L}^{-1}\right)$. E, cyproconazol $(10,4,1,6,0,64,0,256,0,1024,0,04096$, 0,016384, 0,006554, 0,002621, 0,001049 $\mathrm{mg} \mathrm{L}^{-1}$ ). Poços das fileiras: 1 e 2: isolados de São João da Aliança; 3, 4 e 5: isolados da Fazenda Santos; 6, 7 e 8: isolado de CPAC 100

Figura 19. Sensibilidade de isolados de Mycosphaerella musicola aos fungicidas DMIs: epoxiconazole, tebuconazole, pyrenifox e triadimenol. Barras horizontais representam o desvio padrão das médias dos valores de $\mathrm{EC}_{50}$. 101

Figura 20. Sensibilidade de isolados de Mycosphaerella musicola aos fungicidas DMIs: cyproconazole, propiconazole, prochloraz e fluquinconazole. Barras horizontais representam o desvio padrão das médias dos valores de $\mathrm{EC}_{50} \ldots . . . . . .102$

Figura 21. Amplificação de parte do gene CYP51 dos isolados de Mycosphaerella musicola, gerando fragmentos de aproximadamente $1.500 \mathrm{pb}$. Coluna 1: marcador easy Ladder. Coluna 2 à 13: 6 isolados de SJA, 3 de CPAC e 3 de STOS, respectivamente. 104

Figura 22. Alinhamento entre nucleotídeos do gene CYP51 dos 12 isolados de Mycosphaerella musicola: 6 isolados de SJA, 3 de CPAC e 3 de STOS. 105

Figura 23. Alinhamentos entre nucleotídeos de CYP51 do isolado número 2 de Mycosphaerella musicola de São João da Aliança e de $M$. fijiensis (http://genome.jgi-psf.org/Mycfi2/Mycfi2.home.html). Região promotora em laranja, região não codante em vermelho e codante em verde. Códon 461 de $M$. musicola marcado em cinza 107 
Figura 24. Variedades de trigo preparadas para inoculação das estirpes de Mycosphaerella graminicola ST16 e B3-GFP.

Figura 25. Mapa cromossômico de Mycosphaerella graminicola IP0323, mostrando a localização de 3 LysM no cromossomo 11 (estExt_fgenesh1_pg.C_chr_110126). Os números de 1 a 21 correspondem aos cromossomas do patógeno.

Figura 26. Esquema representando o gene 3LysM de Mycosphaerella graminicola IP0323 (seta vermelha), dois genes vizinhos (setas azul e verde) e a região de pareamento dos primers para amplificação do gene 3LysM de B3-GFP.

Figura 27. Esquema representando a região de pareamento dos primers para amplificação do gene 3 LysM de B3-GFP, sem peptídeo sinal. 123

Figura 28. Esquema apresentando o plasmídeo pCGEN e os locais de ação das endonucleases no vetor; e a geração do vetor pCGEN $\Delta$ 3LysM exibindo os insertos FL1 e FL2. 124

Figura 29. Esquema exibindo as regiões flanqueadas pelos primers (representados pelas setas) utilizados para a confirmação da inserção do T-DNA no DNA genômico de B3 $\Delta$ 3LysM. 127

Figura 30. Suscetibilidade de cultivares de trigo às estirpes de Mycosphaerella graminicola B3-GFP e ST16. A. Não hospedeira: cevada Atlas; B. cultivar suscetível: Taichung; C. cultivar resistente: Tonic. 129

Figura 31. Infecção e colonização da linhagem de Mycosphaerella graminicola B3-GFP em folhas de cevada (A, B e C), trigo resistente (D, E e F) e suscetível (G, H e I) nos dias 1, 5, e 10 após a inoculação (dpi). A, B e C, aderência dos esporos (e) na superfície da folha e próximo aos estômatos (e), com início da formação do tubo germinativo (tg). B e C, formação do tubo germinativo (tg). E, F, H e I, penetração das hifas de infecção (hi) através da abertura dos estômatos (ae), nos sítios de penetração ( $\mathrm{sp}$ ). D e $\mathrm{H}$, células do mesófilo com clorofila vermelho fluorescente (cc). Escalas das barras: menores $=10 \mu \mathrm{m}$, maiores $=20 \mu \mathrm{m}$........ 130

Figura 32. Colonização da linhagem de Mycosphaerella graminicola B3-GFP em folhas de trigo suscetível no $14^{\circ}$ dai. A e B, hifas de infecção (hi) nos sítios de penetração ( $\mathrm{sp}$ ) na abertura dos estômatos (ae). B e C, regiões cloróticas ( $\mathrm{rc}$ ) formadas próximas à área de colonização do fungo (setas). Escala das barras: menores $=20 \mu \mathrm{m}$, maiores $=250 \mu \mathrm{m}$. 131 
Figura 33. Colonização da linhagem de Mycosphaerella graminicola B3-GFP em folhas de trigo suscetível no 21 dai. A, hifas de infecção (hi) crescendo no mesófilo e picnídios sem cirrhi (setas). B e C, picnídios com emergência de cirrhi (ci) verde fluorescente emergindo. D, E, F e G, picnídios com cirrhi (ci) distribuídos no centro da área necrosada (an). Escala das barras: menores $=5$ $\mu \mathrm{m}$, intermediária $=10 \mu \mathrm{m}$ e maiores $=250 \mu \mathrm{m}$ 132

Figura 34. Análise em gel de agarose exibindo o fragmento FL1+GEN+FL2 inserido no plasmídeo pCGEN $\Delta$ 3LysM. 134

Figura 35. Colônias de Mycosphaerella graminicola B3 $\Delta 3$ LysM em meio YPD contendo geneticina e timentina. A. primeiras colônias fúngicas de possíveis transformantes; B. Subculturas preparadas a partir das primeiras colônias.... 134

Figura 36. Resultados em gel de agarose, das combinações de primers utilizados para comprovação da transformação de colônias de Mycosphaerella graminicola B3-A3LysM comparados ao controle B3-GFP. A. Esquema representativo das regiões flanqueadas pelos primers; B. primers FL1F e GENinR; C. primers FL1endF e FL2stR. Colunas 1: DNA ladder 1Kb da Invitrogen. Colunas 2: B3-GFP (controle). Colunas 3 a 14: colônias de B3- $\Delta$ LLysM. 135

Figura 37. Alinhamento entre as sequências de nucleotídeos das regiões LysM de Mycosphaerella fijiensis e Mycosphaerella graminicola. 140 


\section{Resumo Geral}

Brito, Fabiane Silva Darosci. Diversidade genética de populações de Mycosphaerella musicola e caracterização de efetores LysM em Mycosphaerella graminicola. Tese de Doutorado em Fitopatologia - Universidade de Brasília, Brasília, DF.

A bananeira (Musa spp.) é cultivada em mais de 100 países, assumindo importante papel social e econômico, visto que é o fruto mais consumido no mundo. A quinta posição no ranking de produção é ocupada pelo Brasil, onde a Sigatoka-amarela é uma doença comum nos cultivos de bananeiras. Mycosphaerella musicola (R. Leach ex. J. L. Mulder 1979) (Anamorfo: Pseudocercospora musae Zimm. Deighton), agente causal da doença, é a espécie de Mycosphaerella de maior ocorrência no país em relação às demais espécies. Pouco se sabe sobre a diversidade genética desse patógeno. Similarmente, pouco se sabe sobre a sensibilidade de M. musicola a fungicidas DMI (inibidores da demetilação). Análises da influência de genes efetores LysM na patogênese de membros do gênero Mycosphaerella também são reduzidas. Nesse contexto, os objetivos da tese foram verificar a ocorrência de recombinação sexual em populações de M. musicola de 13 diferentes zonas produtoras de banana no Brasil, por meio de análises dos genes mating types; caracterizar a diversidade genética das populações com base em 19 locos microssatélites; analisar a sensibilidade dos isolados a fungicidas DMI e correlacionar o resultado com a ocorrência de mutações no gene CYP51 e, como componente adicional do trabalho, caracterizar o efetor de virulência - LysM em Mycosphaerella graminicola. Com exceção de isolados coletados em uma das áreas do Distrito Federal e no Rio Grande do Norte, as populações mostraram proporção de 1:1 de genes MAT1-1-1 e MAT1-21 , indicando a ocorrência de recombinação sexual nessas populações. Alto nível de diversidade genética foi observado entre indivíduos dentro das populações, fato que pode ser resultante da recombinação sexual. Um considerável número de migrantes entre populações de diferentes estados foram observados. Isso indica que ações 
antrópicas, como o transporte de folhas contaminadas, devem ter contribuído para o fluxo gênico e a homogeneização das populações, considerando que a dispersão por ascósporos é incomum a longas distâncias. A alta fração clonal nas populações sugere que a recombinação assexual emprega um importante papel na estrutura genética e apoia as evidências de dispersão conidial dentro das áreas produtoras de banana. Cinco isolados de M. musicola do Distrito Federal exibiram tolerância aos fungicidas tebuconazole, triadimenol e cyproconazole e um ponto de mutação no aminoácido do códon 461 foi observado nos mesmos isolados. Para a caracterização do efetor LysM, a patogenicidade da linhagem B3 de M. graminicola expressando GFP (proteína verde fluorescente) foi avaliada em 18 genótipos de trigo o que permitiu predizer que GFP não influencia na colonização do patógeno. A colonização de B3-GFP em folhas de trigo foi acompanhada via microscopia confocal de varredura a laser (CLSM) confirmando que GFP é expressa durante todo o ciclo de infecção do patógeno em folhas de trigo suscetíveis. Uma transformação via Agrobacterium tumefaciens foi realizada para a obtenção de uma linhagem B3-GFP mutante não funcional para o gene 3 LysM. Entretanto, o DNA homólogo de $3 L y s M$ não foi integrado ao sítio alvo no genoma, sendo necessários novos experimentos para a obtenção da linhagem esperada. Os resultados obtidos contribuem para otimizar a compreensão sobre a epidemiologia do patógeno e aprimorar as medidas de controle da doença.

Palavras chaves: Sigatoka-amarela, microssatélites, mating type, CYP51, LysM. Orientador: Robert Neil Gerard Miller, UnB 


\section{Abstract}

Brito, Fabiane Silva Darosci. Genetic diversity of Mycosphaerella musicola populations and characterization of the LysM effector on the Mycosphaerella graminicola. Doctorate thesis on Phytopathology - Universidade de Brasília, Brasília, DF.

Commercial banana varieties (Musa spp.) are cultivated in over 100 countries, assuming important social and economic roles, given that this fruit is the most widely consumed globally. Brazil is the world's fifth largest producer, where yellow Sigatoka is the most common banana disease in production areas. Mycosphaerella musicola ( $\mathrm{R}$. Leach ex. J. L. Mulder 1979) (Anamorfo: Pseudocercospora musae Zimm. Deighton), causal organism of the disease, is the most commonly occuring Mycosphaerella species in the country. Limited analysis of genetic diversity of this pathogen has been conducted to date. Similary, little is known regarding fungicide sensitivity of M. musicola to DMI (demethylation inhibitor) fungicides. Analysis of pathogen effector LysM genes and their influence on the pathogenesis of Mycosphaerella members is also limited. In this context, the goals of this study were to verify the occurrence of sexual recombination in $M$. musicola populations from 13 different agroecological zones across Brazil, based on analysis of mating type idiomorphs; characterize population genetic diversity by comparison of 19 microsatellite loci; analyse isolate sensitivity to DMI fungicide and correlate the results with the occurrence of mutations in the CYP51 gene and, as a additional component of the work, characterize the virulence effector - LysM in Mycosphaerella graminicola. With the exception of isolates collected in one area of the Distrito Federal and Rio Grande do Norte, populations displayed 1:1 proportions of mating type gene idiomorphs MAT1-1 and MAT1-2, indicating the occurrence of sexual reproduction as an evident process in M. musicola populations. Greatest genetic diversity occurred among individuals within populations, which may be the result of 
sexual recombination. A considerable number of migrants between populations from different states were observed. These results indicate that anthropic action such as transport of contaminated germplasm may be contributing to gene flow and the genetic homogenization of populations, when considering that ascospore dispersal is uncommon over large distances. The high clonal fraction in populations suggests that asexual reproduction plays an important role in the genetic structure, supporting documented evidence of conidial dispersal within banana blocks. Five M. musicola isolates from Distrito Federal exhibited low sensibility to tebuconazole, triadimenol and cyproconazole fungicides, with one point mutation in an amino acid at codon 461 observed across all these isolates. For LysM effector characterization, the pathogenicity of $M$. graminicola strain B3 expressing GFP (green fluorescent protein) was evaluated on 18 wheat genotypes, shown that GFP had no influence on pathogen colonization. Colonization of the B3-GFP in wheat leaves was followed via confocal laser scanning microscopy (CLSM). The results confirmed that GFP is expressed during the whole infection cycle of the pathogen on susceptible wheat leaves. Agrobacterium tumefaciens was used to mediate transformation to generate knockout constructs for 3LysM in B3-GFP. The 3LysM homologous DNA was not integrated in the target genomic site, such that continued experiments are required to develop the desired strain for further analysis of the influence of LysM on M. graminicola pathogenesis. The results contribute to our understanding of pathogen epidemiology and contribute to development of enhanced disease control measures.

Keywords: Yellow Sigatoka, microsatellites, mating type, CYP51, LysM.

Thesis advisor: Robert Neil Gerard Miller, UnB 


\section{Introdução Geral}

A banana (Musa sp.) possui um importante papel social e econômico, principalmente por ser uma das principais fonte de alimento e renda para pequenos produtores e populações pobres de muitos países em desenvolvimento (Araújo et al., 2014). O Brasil está entre os maiores consumidores e produtores mundiais de bananeira. Em 2011, o país produziu aproximadamente sete milhões de toneladas de banana em uma área de aproximadamente 530 mil hectares, valor equivalente a 8\% da produção mundial. Apesar dos números, o Brasil responde por apenas $1 \%$ da exportação mundial do fruto, uma vez que a maior parte da produção nacional é destinada ao mercado interno (IBGE, 2011).

Mycosphaerella musicola, agente causal de Sigatoka-amarela, é um dos principais patógenos que acometem cultivos de bananeiras no Brasil, provocando redução de até 50\% no produção do fruto (Gasparotto et al., 2006). Devido às características reprodutivas, as cultivares de bananeira possuem baixa variabilidade genética (Gasparotto et al., 2006; Heslop-Harrison \& Schwarzacher, 2007) exibindo reduzida resistência genética. Por essa razão, a principal medida empregada no manejo da doença é baseada nas aplicações de fungicidas sistêmicos e protetores (Gasparotto et al., 2001). Como resultado desse uso frequente de fungicidas, populações de patógenos sofrem pressão seletiva e linhagens resistentes podem emergir com capacidade de competir com linhagens tipo selvagem e de superar a sensibilidade original da população selvagem.

A baixa sensibilidade a DMI (inibidores da demetiliação), grupo de fungicidas amplamente utilizados para o controle de Sigatoka-amarela, vem sendo relatada para patógenos do gênero Mycosphaerella, como Mycosphaerella fijiensis e M. graminicola, causadores de Sigatoka-negra em bananeiras e Septoriose em trigo (Triticum), respectivamente. O genótipo de insensibilidade parece estar envolvido com mutações no gene CYP51 (Bean et al., 2009), que age inibindo a esterol 14 $\alpha$ demetilase, enzima da superfamília CYP51 envolvida na biossíntese do ergosterol, 
um composto essencial para a sobrevivência da célula fúngica. Para M. musicola, informações sobre o assunto são ausentes. Diante deste fato, somado à importância do patógeno nos cultivos de bananeiras no país, torna-se necessário realizar análises genéticas de populações de M. musicola, em combinação com uma triagem para resistência a fungicidas DMI, possibilitando o desenvolvimento de estratégias de controle para Sigatoka-amarela.

Similarmente, conhecer a diversidade genética de populações de fungos como M. musicola, e sua distribuição em escala local, regional ou continental, contribui para o desenvolvimento de estratégias para o melhoramento de plantas e o manejo da resistência à Sigatoka-amarela. Ferramentas moleculares têm sido empregadas na resolução de questões filogenéticas e na análise da diversidade genética dos organismos. A região ITS (Internal transcribed spacer) do DNA ribossômico, os genes da actina (ACT) e da histona H3 (HIS) são frequentemente aplicados em estudos de relações taxonômicas entre espécies de Mycosphaerella e seus anamorfos ocorrendo em diferentes plantas hospedeiras (Arzanlou et al., 2008; Crous et al., 2009). Já a análise de genes mating types, além de determinar a identidade sexual de populações de patógenos, é fundamental para predizer a ocorrência de reprodução sexual e assexual, possibilitando correlacionar esta ocorrência com a diversidade genética de uma população e o risco de evolução do patógeno (Conde-Ferráez et al., 2010, Gurung et al., 2011). Em contrapartida, o estudo da diversidade genética de populações fúngicas é possível através do uso de marcadores microssatélites ou SSR (Simple Sequence Repeat). Estes oferecem informações sobre o nível de variabilidade genética presente em virtude de mutações e possível recombinação sexual (Selkoe \& Toonem, 2006).

Soma-se a essas estratégias, a análise de genes de efetores de patógenos, responsáveis por suprimir respostas de defesa na hospedeira durante a patogênese. Proteínas efetoras LysM, já caracterizadas para M. graminicola, estão envolvidas na captura de fragmentos de quitina que são liberados da parede celular do fungo durante a infecção, prevenindo o patógeno da resposta de defesa desencadeada por PAMPs (pathogen-associated molecular patterns) e elicitação da resposta de defesa da planta 
(Bolton et al., 2008; de Jonge et al., 2010). Essas proteínas foram identificadas entre proteínas da folha de Musa acuminata durante a interação com o M. musicola (Passos et al., 2013). Estudos com M. graminicola já demostraram que o patógeno é um valioso modelo para a investigação da interação patógeno x hospedeira (Zwiers et al., 2003; Marshall et al., 2011). Informações geradas sobre a influência de LysM durante a infecção e colonização de $M$. graminicola em folhas de trigo são importantes ferramentas que poderão ser aplicadas em outros patossistemas, principalmente envolvendo espécies biologicamente relacionadas, como M. musicola. 


\section{Objetivo Geral}

Caracterizar a diversidade genética de populações de Mycosphaerella musicola e analisar fatores que levam à resistência do fungo a fungicidas, assim como investigar a influência do efetor LysM na patogênese de Mycosphaerella graminicola.

\section{Objetivos Específicos}

Capítulo 2. Análise da diversidade genética e recombinação sexual em populações de Mycosphaerella musicola

- Identificar e posicionar taxonomicamente isolados de M. musicola, com base na caracterização da região ITS do rDNA e dos genes da actina e histona H3;

- Determinar a identidade sexual dos isolados e predizer a predominância de reprodução (sexuada ou assexuada) das populações, com base na proporção dos genes mating types detectados;

- Analisar a estrutura genética de populações do patógeno oriundas de diferentes genótipos de bananeiras e áreas geográficas através de regiões microssatélites (SSR).

Capítulo 3. Sensibilidade de populações de Mycosphaerella musicola a fungicidas DMIs

- $\quad$ Analisar a sensibilidade de M. musicola a fungicidas DMI;

- Identificar alterações genéticas em homólogo do gene CYP51 de M. musicola.

Capítulo 4. Caracterização do efetor LysM na espécie modelo Mycosphaerella graminicola

- Caracterizar cultivares de trigo específicos para a linhagem B3-GFP de $M$. 
graminicola para verificar a influência de GFP na agressividade do patógeno;

- Acompanhar a colonização da linhagem B3-GFP em folhas de trigo, via microscopia de varredura;

- $\quad$ Gerar linhagem B3-GFP mutante não funcional para o gene $3 L y s M$. 


\section{Capítulo 1: Referencial teórico}

\subsection{Musa}

\subsubsection{Importância da banana}

A bananeira (Musa spp.) é cultivada em mais de 120 países, entre tropicais e subtropicais, assumindo importante papel social e econômico, visto que é o fruto mais consumido no mundo e, muitas vezes, fonte de subsistência em países do continente Africano, onde o consumo anual por pessoa pode chegar a $400 \mathrm{~kg}$ (Kiiza et al., 2006). O Sul e Sudeste do continente Asiático são caracterizados como os centros de origem da planta. Contudo, existem alguns centros secundários de origem na África Oriental e nas ilhas do Pacífico, além de um importante centro de diversidade na África Ocidental (Dantas et al., 1997).

O Brasil ocupa a quinta posição no ranking de produção em seguida da Índia, China, Filipinas e Equador (FAOSTAT, 2012). Nas regiões Nordeste e Sudeste concentra-se a maior produção de banana, com aproximadamente 39 e 32\%, respectivamente, estando o Centro Oeste com apenas 3\% da produção nacional. Bahia e São Paulo são os estados brasileiros responsáveis por aproximadamente $35 \%$ de toda produção de banana no país, seguidos por Minas Gerais (9\%), Santa Catarina (9\%) e Pernambuco (7\%) (IBGE, 2011). No Brasil, a bananicultura é a atividade agrícola mais antiga, com consumo médio de $31 \mathrm{~kg} /$ habitante, superado apenas pela laranja com média de $43 \mathrm{~kg} /$ habitante (FAOSTAT, 2011).

O fruto é um alimento altamente energético (cerca de $100 \mathrm{kcal}$ por $100 \mathrm{~g}$ de polpa), cujos carboidratos (aproximadamente 22\%) são facilmente assimiláveis. Embora pobre em proteínas e lipídios, seus teores superam os da maçã, pera, cereja ou pêssego. Contém teores de vitamina $\mathrm{C}$ similares aos da maçã, além de razoáveis quantidades de vitaminas A, B1, B2, pequenas quantidades de vitaminas D e E, e 
maior percentagem de potássio, fósforo, cálcio e ferro do que outros frutos, como a maçã ou a laranja (Medina, 1995).

Classificar e descrever as principais cultivares de banana tem sido objeto de alguns estudos (Silva et al., 1997; Silva et al., 2000). Quando aspectos como a preferência dos consumidores, tolerância a pragas e doenças, resistência à seca, porte e resistência ao frio são considerados, poucas cultivares com potencial agronômico podem ser usadas comercialmente, apesar da existência de milhares de genótipos. Mundialmente, a produção é dominada por bananas Cavendish suscetíveis a Sigatokanegra e Sigatoka-amarela. No Brasil, entre os principais cultivares estão: Prata, Prataanã, Maçã, Grand Naine, Pavocan, Caipira, Thap Maeo (Leite et al., 2003).

\subsubsection{Classificação taxonômica de Musa}

As bananeiras são plantas pertencentes à família Musaceae L., ordem Zingiberales Grisebach, superordem Lilianae, subclasse Zingiberidae, classe Lilipsida (Cheesman, 1947). A família Musaceae é dividida em três subfamílias: Heliconoideae, Strelitzoideae e Musoideae. Dentro da subfamília Musoideae encontram-se os gêneros Ensete e Musa. O gênero Musa era dividido em quatro seções, considerando os números de cromossomos e características morfológicas: Callimusa (número de cromossomos igual a 10 ou 11), Australimusa $(\mathrm{n}=10)$, Eumusa e Rhodochlamys $(\mathrm{n}=11)$ (Cheesman, 1947). A partir de 1976, foi criada a seção Ingentimusa para acomodar uma espécie solitária, Musa ingens, que exibe sete pares de cromossomos. Contudo, recentemente, baseando-se em análises moleculares, o gênero foi reclassificado em apenas duas seções. A seção Musa engloba os representantes das antigas Eumusa e Rhodochlamys, e a nova seção Callimusa inclui as espécies das antigas seções Australimusa e Callimusa, além de abrigar o único representante da seção Ingentimusa, M. ingens (Häkkinen, 2013).

A seção Callimusa possui espécies de plantas que não produzem frutos comestíveis, sendo apenas de interesse ornamental. As espécies que fazem parte da antiga seção Australimusa (atual Callimusa) apresentam importância industrial, pois 
delas são retiradas fibras têxteis para confecção de redes para pesca. Já as bananeiras cultivadas, teoricamente, são originárias das espécies pertencentes a seção Musa (antiga Eumusa), que possui cerca de 11 espécies. A evolução da maioria das cultivares de banana ocorreu a partir do cruzamento inter e intraespecífico de duas espécies selvagens, diplóides, Musa acuminata Colla e Musa balbisiana Colla, cujas variedades apresentam níveis cromossômicos di, tri ou tetraplóides, com 22, 33 ou 44 cromossomos, em combinações variadas denominas pelas letras AA (M. acuminata) e BB (M. balbisiana) (Simmonds \& Shepherd, 1955).

A maioria das cultivares comerciais de banana são triplóides estéreis, com frutos sem sementes desenvolvidos por partenocarpia - ausência de fecundação (Raven et al., 2001) - e evolução através de propagação vegetativa assexual. A inexistência de sementes em cultivos comerciais é resultado da ausência de pólen viável ou, talvez, de polinizadores naturais eficientes. Tal fato contribui para a ausência de variação genética que resulta em lavouras com pouca resistência a pragas e doenças, gerando um contínuo embate entre as variedades de Musa existentes e novas doenças e raças virulentas (Gasparotto et al., 2006; Heslop-Harrison \& Schwarzacher, 2007).

\subsubsection{Problemas fitossanitários}

A bananeira é hospedeira de patógenos causadores de doenças que geram elevados níveis de perdas, constituindo a maior fator limitante na produção. Os principais problemas sanitários nos cultivos de banana são provocadas por bactérias (ex. Ralstonia solanacearum e Xanthomonas campestres pv. musacearum), nematóides (ex. Rhadopholus similis e Pratylenchus coffeae), vírus (ex. Banana streak virus) e fungos (Gasparotto et al., 2006). Esses últimos, por sua vez, causam os maiores impactos na produtividade da cultura, estando entre eles Fusarium oxysporum f. sp. cubense, Colletotrichum musae, Mycosphaerella fijiensis e Mycosphaerella musicola. As duas últimas espécies pertencem a um dos maiores gêneros causadores de doenças dos Ascomicetes, pertencentes à família 
Mycosphaerellaceae (Capnodiales, Dothideomycetidae), compartilhando características como ascomas solitários, ascos bitunicados e ascósporos septados (Crous et al., 2009). Elas estão entre cerca de 20 espécies do gênero ou seus anamorfos (Arzanlou et al., 2008), distribuídas por todas as regiões no mundo, adaptando-se a diferentes nichos ecológicos, como saprófitas, patógenos de plantas e endofíticos (Crous et al., 2009). Ao lado de Mycosphaerella eumusae (anamorfo: Pseudocercospora eumusae), que é somente encontrada em parte da Ásia e Oeste da África (Carlier et al., 2000), M. fijiensis (Morelet) (anamorfo: Pseudocercospora fijiensis) e M. musicola (R. Leach ex. J. L. Mulder 1979) (anamorfo: Pseudocercospora musae) são os patógenos do gênero envolvidos em um complexo de doenças da bananeira, denominado Sigatoka, encontrado em todas as regiões onde a planta é cultivada, incluindo o Brasil.

\subsubsection{Origem da Sigatoka}

A cronologia de registros da Sigatoka sugere que, assim como para seu hospedeiro, o Sudeste da Ásia seja o centro de origem para os patógenos (Arzanlou et al., 2010). A Sigatoka-amarela, causada por M. musicola, foi primeiramente descrita na banana em Java por Zimmermann em 1902. Em seguida, a doença foi relatada no distrito de Sigatoka na ilha de Viti Levu, em Fiji, no ano de 1912. Durante os 40 anos seguintes, ela se tornou uma séria doença epidêmica de escala global e foi identificada na Ásia, África, Américas Central e do Sul e Caribe (Meredith, 1970). A Sigatokanegra, causada por M. fijiensis, foi identificada pela primeira vez em 1963, também em Fiji, entretanto, pode ter sido distribuído no Pacífico antes dessa data, com alguns relatos sugerindo sua presença em Taiwan em 1927 (Stover, 1978). Em 40 anos, M. fijiensis disseminou-se pelo mundo, se adaptando e substituindo M. musicola em condições de climas mais quentes e úmidos e deslocando este último para regiões mais frias e altitudes elevadas (Churchill, 2011).

No Brasil, a Sigatoka-amarela foi constatada pela primeira vez em 1944, no estado do Amazonas (Kimati \& Galli, 1980), estendendo-se, posteriormente, por 
todos os estados brasileiros. Já a Sigatoka-negra teve seu primeiro relato em 1998 também no Amazonas, com o patógeno, subsequentemente, disseminando-se nos sete estados do norte do país (Gasparotto et al., 2006). Em 2005, o patógeno foi relatado também em São Paulo, Paraná e Santa Catarina. Desde então M. fijiensis não foi relatada em novas áreas, embora ameace a região Nordeste (Matos \& Cordeiro, 2011). A esperada mudança de posição quanto ao grau de importância entre Sigatokaamarela e Sigatoka-negra, quase duas décadas após a introdução no Brasil, na prática ainda não aconteceu. A Sigatoka-amarela, por ser de maior ocorrência, continua sendo de grande importância nas regiões de bananicultura mais competitivas, como é o caso do Nordeste, Sudeste e Sul (Cordeiro, 2007). Contudo, em condições de umidade e temperatura favoráveis, M. fijiensis pode causar as maiores perdas na produtividade do fruto. Sintomas das Sigatokas incluem amadurecimento precoce do fruto, lesões necróticas e decomposição foliar, assim como perdas no produção de até 100\% nas variedades suscetíveis Cavendish (Musa cv. AAA) e Prata (Musa cv. AAB) (Cordeiro \& Matos, 2003).

\subsection{Mycosphaerella musicola}

\subsubsection{Biologia}

A infecção de $M$. musicola começa com os esporos sendo depositados nas superfícies das folhas da bananeira. Os esporos germinam 2-3 horas após a deposição, se houver a presença de filme d'água ou se a umidade for elevada. A temperatura ótima para a germinação dos conídios varia entre $25^{\circ}$ e $29^{\circ} \mathrm{C}$ e para os ascósporos entre $25^{\circ}$ e $26^{\circ} \mathrm{C}$. O tubo germinativo cresce epifiticamente por vários dias (4-6 dias) antes da penetração nas folhas via estômatos em resposta hidrotrópica através da formação de apressórios sobre os estômatos (Figura 1) (Meredith, 1970, Stover, 1980).

M. musicola pode produzir três tipos de frutificações nas manchas foliares em bananeiras: esporodóquios, espermagônio e peritécios (Stover, 1970). Os 
espermagônios, formados no processo sexual de Mycosphaerella, produzem gametas masculinos, as espermácias, e o órgão feminino, uma hifa espiralada, formada no interior de jovens ascocarpos, denominadas tricógines (Wardlaw, 1961). Em escala macroscópica, os espermagônios, assemelham-se às pontuações negras formadas pelas frutificações conidiais, porém com um formato delimitado de pontuação. Estas estruturas podem ser formadas em ambas as superfícies foliares, porém com maior predominância na abaxial. Sob microscópio de luz, os espermagônios são pequenas frutificações negras imersas em formato de frascos, que surgem no interior de uma base estromática de velhas frutificações conidiais ou independentemente. As espermácias, que são formadas em longas cadeias, são minúsculas, oblongas e hialinas, com formato semelhante a bactérias, e podem ser visualizadas sendo expelidas a partir de um ostíolo ou poro no ápice dos espermagônios (Simmonds, 1933).



Figura 1. Ciclo de vida de Mycosphaerella spp em bananeira (Churchill, 2011). 
Dois tipos de esporos estão envolvidos no desenvolvimento da doença: o ascósporo, esporo sexuado e o conídio, esporo assexuado. Os conídios são produzidos durante o dia em ambientes úmidos de forma contínua, sendo disseminados pela água acumulada na superfície foliar durante as chuvas ou orvalho, explicando assim, as infecções severas algumas vezes observadas nos perfilhos situados sob as plantas mais adultas e infectadas. Os ascósporos porém, produzidos nas mesmas lesões onde foram liberados os conídios anteriormente, surgem mais tardiamente, sendo ejetados a partir dos pseudotécios em períodos de alta umidade à noite, ou mesmo durante o dia porém com ocorrências de orvalhos pesados (Simmonds, 1966).

Conídios são dispersos principalmente por gotas de chuvas e ascósporos podem ser transportados pelo vento a partir de plantas infectadas e viajar várias dezenas de quilômetros, sempre da fonte da doença. Ascósporos possuem o papel epidemiológico mais importante. Entretanto, a exposição aos raios ultravioletas da luz solar pode restringir a dispersão de esporos viáveis a longas distâncias (Halkett et al., 2010).

\subsubsection{Sintomas da Sigatoka-amarela}

As lesões de Sigatoka-amarela apresentam-se em formatos distintos, de acordo com a idade da planta hospedeira infectada. McGahan \& Fulton (1965) observaram que em folhas de plantas jovens as lesões possuem formato elíptico e são maiores e mais largas do que nas plantas adultas, onde as lesões apresentam-se em formato linear. De acordo com Meredith (1970), o desenvolvimento das lesões foi classificado em seis fases (Figura 2): I- Fase inicial de listra -pontuação perceptível ao olho nú, com leve mancha de descoloração verde amarelada; II- Segunda fase de listra - a mancha aumenta de tamanho, permanecendo com cor verde amarelada; III- Terceira fase de listra - a mancha começa a dilatar-se tornando o centro da lesão com coloração avermelhada enferrujada; IV- Primeira fase de mancha - a listra torna-se marrom escuro e, simultaneamente, forma-se um halo marrom visível à luz solar. Neste estádio a listra aumenta de tamanho sendo facilmente reconhecida como uma lesão 
circular. V-Segunda fase de mancha - halo torna-se de coloração mais escurecida. VI - Terceira fase de mancha - a mancha encontra-se plenamente desenvolvida: porção central abaulada e de coloração cinza, halo de coloração marrom escuro ou preto.
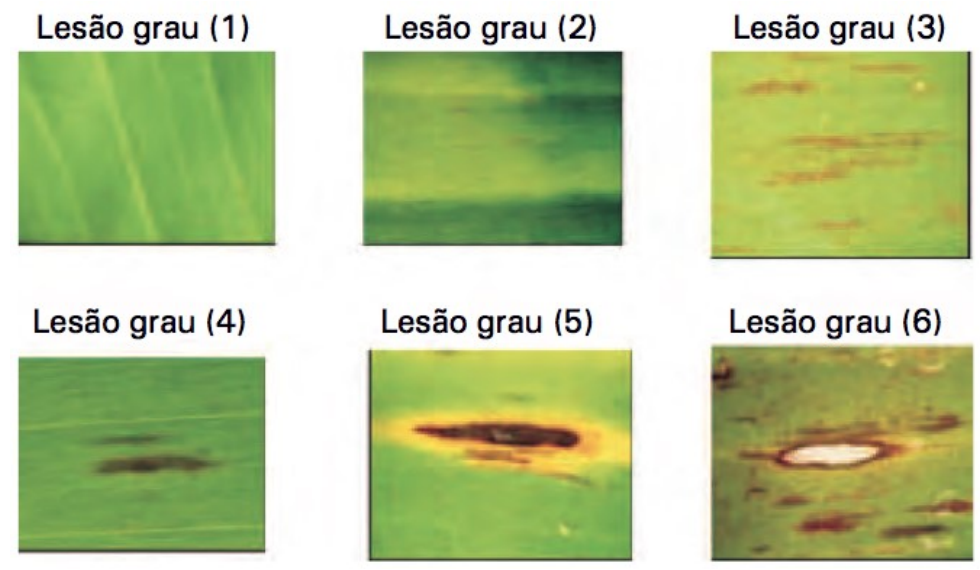

Figura 2. Diferentes graus de desenvolvimento das lesões de Sigatoka-amarela (Cordeiro et al., 2011).

Linhas regulares de esporodóquios podem ser observadas no centro de lesões ativas. Com o progresso e desenvolvimento da doença, novas lesões nas folhas e grandes áreas necróticas no tecido foliar podem ocorrer (Cordeiro, 1999; Gomes et al., 2013). De acordo com Leach (1946), embora as injúrias ao limbo foliar sejam intensas, a doença não afeta o desenvolvimento vegetativo completamente. Entretanto, a redução da área fotossintética ativa resulta na redução do tamanho dos frutos e do tamanho e número de cachos (Simmonds, 1966).

\subsection{Controle da Sigatoka-amarela}

Entre as alternativas para o controle de Sigatoka-amarela estão os programas de melhoramento da bananeira. Em contraste com lavouras onde o melhoramento convencional é baseado em cruzamentos entre as variedades elites e seleção de 
progênie, o melhoramento de bananeiras por esse processo é impedido devido as características biológicas da planta, como a ausência de fecundação. Contudo, o melhoramento genético se torna uma importante alternativa para o controle. Mas a dificuldade de aliar em uma única cultivar a resistência genética a doenças com características necessárias para o consumo, exige o emprego de outras medidas de controle.

Tendo assim, a principal medida empregada no manejo da doença é baseada nas aplicações de fungicidas sistêmicos e protetores. Algumas vezes, quando a pressão da doença é alta, até 52 aplicações de fungicidas protetores ou 26 aplicações de fungicidas sistêmicos podem ser necessárias por ano (Gasparotto et al., 2001).

As consequências do uso excessivo de fungicidas são o aumento do custo da produção e o impacto negativo no ambiente. $\mathrm{O}$ uso frequente de fungicidas sistêmicos pode exercer uma pressão seletiva nas populações de patógenos e levar à emergência de linhagens resistentes capazes de competir com populações tipo selvagens. Considerando o exposto, análises genéticas de populações de patógenos em combinação com um triagem para resistência, para fungicidas comumente empregados no controle de doenças, são de fundamental importância para o desenvolvimento de estratégias anti-resistência, baseadas na redução do número de pulverizações, escolha racional da mistura ou alternância de agroquímicos.

As sete principais classes de fungicidas empregadas atualmente no controle das Sigatokas são os inibidores de demetilação (DMIs, azoles), aminas, quinone outside inhibitors (Qols; estrobirulinas), anilinopirimidinas (APs), metil benzimidazoles carbonatos (MBCs), inibidor succinate desidrogenase (SDHIs) e guanidinas (Cañas-Gutiérrez et al., 2009; Churchill, 2011; www.frac.info). Embora todos os grupos possam ser usados no controle das doenças, os DMIs são os mais empregados em todo o mundo para o controle das Sigatokas. 


\subsubsection{Fungicidas inibidores de demetilação - DMIs}

Os DMIs, um grande grupo de fungicidas denominado azole (imidazóis e triazóis), estão entre os mais comumente usados para o controle de patógenos fúngicos humanos e de plantas, dominando o mercado de fungicidas agrícolas desde sua introdução na década de 1970 (Cools et al., 2013). Seu emprego em Sigatokanegra se iniciou por volta de 1987, mas apenas em 1991 o propiconazol, um DMI, se tornou mais utilizado no controle desta doença, como alternativa a ampla resistência dos patógenos ao MBC (benomil) (Marín et al., 2003, Cañas-Gutiérrez et al., 2009). Entretanto, a intensa aplicação de propiconazol também causou pressão seletiva favorecendo o aparecimento de linhagens mutantes resistentes (Cañas-Gutiérrez et al., 2009). Entre os principais representantes dos fungicidas DMI, estão os grupos químicos imidazol e triazol. Entre os principais imidazole estão os pefurazoate, prochloraz e triflumizole e entre os triazóis estão: azaconazol, bitertanol, bromuconazol, cyproconazol, difenoconazol, epoxiconazol, fenbuconazol, fluquinconazol, ipconazol, propiconazol, tebuconazol, tetratonazol, triadimenol, triticonazol (www.frac.info).

Em contraste com outros fungicidas e apesar de ser amplamente empregadas, falhas no controle com DMIs são raras (Cools et al., 2013). Ao contrário de mutações nos sítios alvos causando resistência a vários fungicidas, mutações em CYP51 (gene envolvido na resistência a essa classe de fungicidas) afetam a resistência a um único DMI ou a um subconjunto desse composto, com resistência cruzada a toda a classe geralmente incompleta. Sendo assim, quando a resistência ocorre, o nível e a frequência são baixos e a resistência cruzada entre membros da classe DMI é incompleta. Por essa razão, o controle da doença pode ser mantido pelo uso de outros compostos ativos da mesma classe (Cools et al., 2013).

O controle de Sigatoka-amarela é atualmente dependente do frequente uso de fungicidas DMIs. Entretanto, a baixa sensibilidade de M. musicola a esses fungicidas ainda tem sido pouco relatada, com registros encontrados apenas para o propiconazole (Peterson et al., 2002). Além disso, não foram relatados estudos relacionando 
fenótipos de resistência a fungicidas com mutações nos genes alvos correspondentes e estratégias de manejo da doença para um controle mais sustentável não são empregadas. Por essas razões, e pelo fato de M. musicola ser atualmente um dos patógenos fúngicos mais importantes em regiões produtoras de banana no Brasil, a investigação detalhada em torno da tolerância e resistência a fungicidas DMIs é necessária.

\subsubsection{Fatores envolvidos no desenvolvimento de resistência a fungicidas}

O desenvolvimento de resistência de um patógeno a fungicidas pode ser influenciado pela classe química a que o produto pertence ou até mesmo por diferentes membros de uma mesma classe. Cada classe química é caracterizada por um padrão típico de resistência (Brent \& Hollomon, 2007). Ocorrem variações nas atividades intrínsecas e nos fatores de resistência, ambos afetando a pressão de seleção, o grau de resistência encontrado e a eficácia contra populações de patógenos parcialmente resistentes (Brent \& Hollomon, 2007). Os fatores que podem contribuir para a resistência de fitopatógenos a fungicidas podem ser a combinação da ocorrência natural de indivíduos resistentes, inicialmente em baixa frequência, originados de recorrentes mutações conferindo resistência e de recombinações sexual e assexual (Gisi et al., 2002).

A base do desenvolvimento da resistência frequentemente envolve alterações bioquímicas do sítio alvo do patógeno como, por exemplo, substituições de aminoácidos em genes que codificam proteínas alvo e afetam a afinidade de ligação do fungicida ao alvo (Brent \& Hollomon, 2007).

Por ser eficaz e com amplo espectro, DMIs têm a maior participação no mercado de fungicidas e são fortemente indicados para o controle de Sigatokaamarela na bananeira. Estes fungicidas são sistêmicos, com propriedades protetoras e curativas. Entretanto, a maioria dos fungicidas modernos, como os DMIs, inibem uma única enzima (proteína), tornando-se uma desvantagem uma vez que fungicidas com sítio específico de ação aumentam o risco de desenvolvimento de resistência (Brent \& 
Hollomon, 2007). Por outro lado, inibidores de multi-sítios, voltados para múltiplas proteínas, apresentam menor risco de resistência mas são geralmente menos efetivos, mais tóxicos para o ambiente e não são sistêmicos.

$\mathrm{O}$ risco de desenvolvimento de resistência a fungicidas no patógeno para um fungicida particular deveria ser determinado separadamente para cada combinação de fungicida/patógeno motivado por diferenças no estilo de vida do patógeno (ex. período de latência, esporulação, estágio sexual, hospedeira alternativa e transmissão por sementes), nas propriedades químicas do fungicida (ex. modo de ação, eficácia e estabilidade) e exposição (ex. práticas ambientais e agronômicas) (Gisi et al., 2002).

O desenvolvimento de estratégias para retardar o desenvolvimento de resistência em populações de patógenos requer investigação no nível molecular, do indivíduo e da população (Gisi et al. 2002). Dada a atual escassez ou mesmo ausência de informações em torno do desenvolvimento da resistência a fungicidas em populações de $M$. musicola, uma análise integrada é essencial para o desenvolvimento de estratégias que otimizem o controle da doença, evitando e/ou atrasando o desenvolvimento da resistência.

\subsubsection{Modo de ação dos fungicidas e mecanismos de resistência em fungos}

A maioria dos fungicidas DMIs são sistêmicos, absorvidos e translocados pela planta de forma acropetal. Alguns fungicidas do grupo podem atuar como protetores uma vez que exibem alta fungitoxicidade, rápida penetração e translocação nos tecidos vegetais e assim elevado efeito residual. Adicionalmente, apresentam ação tóxica sobre a germinação dos esporos, sobre a formação do tubo germinativo e na formação de apressório. Há também fungicidas com ação curativa uma vez que o desenvolvimento do haustório e o crescimento micelial no interior dos tecidos dos hospedeiro podem ser inibidos pela presença do fungicida (Ehr \& Kemmitt, 2002; Forcelini, 1994)

Fungicidas DMIs agem inibindo a esterol 14 $\alpha$-demetilase, uma enzima da superfamília CYP51 envolvida biossíntese do ergosterol. Este último, por sua vez, é 
importante para os fungos por regular o fluido na membrana e a permeabilidade das células fúngicas, sendo essencial para a sobrevivência da célula (Lepesheva \& Waterman, 2004; Cools et al., 2013).

O desenvolvimento de baixa sensibilidade em populações de patógenos fúngicos a DMI parece estar envolvida com mutações no gene CYP51. Em M. fijiensis, a resistência está correlacionada com uma ou mais de sete (Y136F, A313G, Y461D, Y463D, Y463H, Y463N e Y463S) mutações pontuais na sequência do gene CYP51 que codifica a enzima esterol 14 $\alpha$-demetilase (Cañas-Gutiérrez et al., 2009). Esse fenômeno também foi observado em outras espécies como Mycosphaerella graminicola (Zymoseptoria tritici), patógeno de trigo (Triticum sp.), sendo $17 \mathrm{o}$ número de alterações (substituições ou deleções) nos aminoácidos, da proteína MgCYP51, relatado para a espécie em questão (L50S, V136A/C, Y137F, S188N, A379G, I381V, Y459D/S/N/C, G460D, Y461H/S, $\Delta$ Y459/G460, G510C e N513K (Cools \& Fraaije, 2008, Cools et al., 2010). Análises da esterol 14 $\alpha$-demetilase contida em isolados de $M$. graminicola com diferentes variantes de CYP51, sugerem que algumas alterações podem afetar a capacidade de $M$. graminicola para metabolizar eburicol, o substrato de CYP51 em fungos filamentosos (Bean et al., 2009). Similarmente, mutações correspondentes à resistência a DMIs têm sido identificadas em outros CYP51 de fungos, incluindo patógenos humanos oportunistas, como Candida albicans (Marichal et al., 1999) e Aspergillus fumigatus (Ferreira et al., 2005).

Muitas mutações em CYP51 relatadas em fungos possuem sítios equivalentes em patógenos humanos e de plantas, e outras mutações um único sítio para uma espécie ou gênero (Beher \& Wirsel, 2012). Cools e colaboradores (2011) caracterizaram funcionalmente o impacto do número de mutações no gene CYP51 de M. graminicola na sensibilidade a DMI. Mullins et al. (2011), usando modelagem da proteína de CYP51 e estudos de acoplamento de DMI, confirmaram a importância de várias substituições (ex. Y137F, I381V e V136A) e as deleções de dois aminoácidos (Y459/G460) na ligação do DMI, em particular de triadimenol, tebuconazol e a prochloraz. Os autores evidenciam que essas ligações dos DMIs a variantes do gene 
CYP51 podem ser diferencialmente afetadas pelas alterações nos aminoácidos. A complexa evolução de variantes de CYP51 em populações de campo ao longo do tempo reflete a diferente pressão seletiva exercida por diferentes DMIs disponíveis no mercado. A mais recente variante de CYP51 em M. graminicola tem até oito aminoácidos alterados quando comparados ao tipo selvagem e mostra altos níveis de resistência à maioria dos DMIs atualmente em uso (Cools et al., 2010).

A identificação de alterações no gene CYP51, equivalentes em isolados de $M$. fijiensis e M. graminicola, como Y461-Y463 correspondentes a Y459-Y461, respectivamente, pode sugerir uma propensão para mudanças nessa região em outros fungos geneticamente relacionados como M. musicola, quando sob pressão seletiva por aplicação de DMI. Embora M. musicola esteja amplamente difundido no Brasil e altas dosagens de fungicidas sejam usadas no seu controle, poucas informações estão disponíveis sobre a sensibilidade do patógeno a diferentes fungicidas do grupo. Resistência a DMI foi relatada para M. fijiensis em outros países, mas pouco se sabe sobre os mecanismos moleculares de desenvolvimento da resistência no Brasil (Cañas-Gutierrez et al., 2009), tampouco para M. musicola.

O conhecimento da genética e epidemiologia do patógeno, o estado de resistência a fungicidas e os mecanismos de resistência envolvidos podem ser usados para a gestão de estratégias de manejo mais sustentáveis, com menos impacto para o ambiente.

\subsection{Deteç̧ão de Mycosphaerella musicola}

Um importante componente para o adequado manejo da doença é a correta detecção e identificação dos patógenos. Tradicionalmente, Sigatoka-negra e Sigatokaamarela são diagnosticadas com base nos sintomas da doença, características morfológicas e padrão de germinação dos anamorfos dos patógenos causadores das doenças (Arzanlou et al., 2007, Gomes et al., 2013). Entretanto, as três espécies de Mycosphaerella, M. fijiensis, M. musicola e M. eumusae, causam similares sintomas,

podendo coexistir numa mesma folha de bananeira, dificultando o diagnóstico da 
doença. Adicionalmente, a morfologia conservada e não específica dos teleomorfos impossibilita diferenciação entre estas espécies, mesmo quando os peritécios ou os ascósporos são comparados (Gomes et al., 2013). A maior diferença morfológica entre as espécies é encontrada no estado anamórfico. Conidióforos de M. musicola, similarmente a $M$. eumusae, produzem denso fascículo (esporodóquios) em um estroma negro, enquanto os conidióforos de M. fijiensis emergem solitariamente ou em pequenos grupos, com estroma ou esporodóquio ausentes. Embora protocolos para a identificação e diferenciação de M. musicola e M. fijiensis, com base na morfologia das espécies, tenham sido publicados por Aguirre-Gaviria e colaboradores (1999) e Jacome \& Schuch (1993), a diagnose das doenças requer muita experiência para evitar erros de identificação.

\subsubsection{Identificação molecular}

Análises moleculares somadas às observações de características morfológicas têm sido utilizadas como importantes ferramentas para a resolução de problemas taxonômicos, possibilitando a correta identificação e distinção de patógenos estreitamente relacionados. Alguns métodos moleculares baseados em Southern blot $\mathrm{e}$ hibridização foram inicialmente utilizados para a diagnose e distinção de M. musicola e M. fijiensis (Johanson et al., 1994, Carlier et al., 1994). Entretanto, por serem altamente laboriosos e exigirem grandes quantidades de DNA, caíram em desuso, sendo substituídos por técnicas mais rápidas, fáceis e sensíveis a baixas concentrações de DNA, como a PCR (Polymerase Chain Reaction). A técnica utiliza primers específicos para a amplificação de diferentes genes que, em gel, podem revelar polimorfismo ao nível de sequências de DNA suficientes para determinar diferenças inter e intraespecíficas. A adoção dessa importante ferramenta molecular para a análise de diferentes regiões do genoma pode aumentar nossa compreensão sobre relações filogenéticas e diversidade genética de populações de fungos (Queiroz et al., 2013). 
Análises da região ITS (Internal transcribed spacer) do DNA ribossômico, dos genes da actina (ACT) e da histona H3 (HIS), têm sido frequentemente aplicadas em estudos de relações filogenéticas entre espécies de Mycosphaerella e seus anamorfos de diferentes plantas hospedeiras (Arzanlou et al., 2008; Crous et al., 2009).

\subsubsection{Internal Transcribed Spacer - ITS}

Considerada atualmente como um código de barras formal de DNA para a identificação molecular de fungos (Schoch et al., 2012), a região ITS (ITS1 e ITS2) vem sendo usada durante mais de duas décadas, devido ao seu alto grau de variabilidade interespecífica, presença de sítios conservados para primers e por apresentar múltiplas cópias naturais no genoma (Blaalid et al., 2013). Em fungos, a região ITS varia, com algumas exceções, entre aproximadamente 450 a 750 pares de base de comprimento (Crous et al., 2011, Blaalid et al., 2013). Ela está localizada entre as subunidades gênicas $18 \mathrm{~S}, 5.8 \mathrm{~S}$ e $28 \mathrm{~S}$ do RNA ribossômico, que são importantes componentes estruturais e catalíticos do ribossomo - o sistema de síntese proteica da célula (Madigan et al., 2010). Usualmente, a região ITS é referida como a região contínua do ITS1, gene 5.8S e ITS2 (Figura 3). Esse conjunto de regiões e subunidades compondo parte do DNA ribossômico (rDNA) frequentemente atinge centenas de repetições por cromossomo em organismos eucariotos. Comparadas aos genes acoplados que são altamente conservados, as regiões ITS1 e ITS2 são polimórficas, tornando-as valiosas para a identificação de fungos ao nível de gênero e espécie (Blaalid et al., 2013). A identificação de M. musicola e sua diferenciação de fungos estreitamente relacionados, como $M$. fijiensis e $M$. emusae, tem sido realizada com base no polimorfismo da região ITS do rDNA genômico (Crous et al., 2001; Hayden et al., 2003). Crous e outros (2011) também utilizaram a região para uma análise filogenética do complexo Mycosphaerella, para a introdução de novas espécies ao gênero. $\mathrm{O}$ polimorfismo se deve a diferenças em alguns nucleotídeos e no 
tamanho da região, que podem ser identificados com a análise dos fragmentos amplificados com o uso de primers universais (Blaalid et al., 2013).



Figura 3. Mapa genético de uma unidade do rDNA em eucariotos mostrando a região ITS (ITS1 e ITS2) e as subunidades flanqueadas pela mesma.

\subsubsection{Genes da actina e histona $\mathrm{H3}$}

Embora a região ITS seja considerada um código de barras de DNA, para alguns grupos de fungos, como as Cercósporas, outros marcadores ou marcadores adicionais são necessários para fornecer a resolução necessária para diferenciação interespecífica (Blaalid et al., 2013). Neste sentido, os genes ACT e HIS têm sido utilizados para fornecer maior precisão às análises filogenéticas de fungos.

O gene ACT codifica a actina, uma proteína abundante em todas as células eucarióticas, onde é o maior componente dos microfilamentos citoplasmáticos. Devido às restrições estruturais, a sequência de aminoácidos da proteína é altamente conservada (Hightower \& Meagher, 1986). Contudo, a sequência de DNA, em particular o terceiro códon, mostra variação significativa entre táxons estreitamente relacionados (Daniel et al., 2001).

As moléculas de histonas de eucariotos, denominadas: H2A, H2B, H3 e H4, estão entre as proteínas mais conservadas e participam da organização do DNA dentro do nucleossomo e cromatina. Cada histona possui uma cauda de aminoácidos terminais (N-terminal) a qual está sujeita a diversas modificações pós-traducionais com função na maioria dos processos biológicos envolvidos na expressão do DNA (Kouzarides, 2007). Embora as histonas e algumas de suas modificações sejam 
altamente conservadas, estudos demonstram que a histona $\mathrm{H} 3$ é, entre todas, a mais variável entre espécies de microrganismos (Wei et al., 1998; Hsu et al., 2000; Ahn et al., 2005).

Crous e colaboradores (2004) utilizaram a região ITS, os genes ACT e HIS, além dos genes de fator de elongação 1- $\alpha$ e calmodulina, para analisar a especificidade de hospedeiras entre espécies de Mycosphaerella (ex. Mycosphaerella acaciigena, Mycosphaerella thailandica e Mycosphaerella citri) em acácias na Austrália. Arzanlou et al. (2007) desenvolveram primers espécie-específico com base nas sequências dos genes da actina e beta tubulina, conseguindo um rápido método de diagnose, detecção e distinção entre M. musicola, M. fijiensis e M. emusae. Com os mesmos primers para o gene da actina, Vázquez-Euán et al. (2011) também conseguiram distinguir M. musicola de M. fijiensis.

\subsection{Recombinação sexual - Mating type}

M. musicola é hemibiotrófico, heterotálico e pode apresentar reprodução sexuada que, juntamente com outros fatores como mutação, heterocariose, herança citoplasmática, transposons e parassexualidade, são fontes de variabilidade genética para essa e outras populações de patógenos, podendo causar profundos efeitos na composição genética das mesmas (Hamrick, 1982; Brent \& Hollomon, 2007; James et al., 2010).

O papel e importância do ciclo sexual é mais pronunciado em fungos patogênicos com exclusiva reprodução cruzada, onde o esporo sexual fornece o inóculo infeccioso (James et al., 2010). Esse fato não descarta a importância desse ciclo em espécies de fungos com combinação de ciclo sexual e assexual, como $M$. musicola, uma vez que o ciclo sexual se torna importante para a distribuição do patógeno, para a produção de inóculo aéreo, para o aumento do tamanho da população, bem como para a geração de variabilidade ao nível populacional e para a velocidade com que um possível gene de resistência a doença possa se disseminar (Brent \& Hollomon, 2007; James et al., 2010). 
A identidade sexual do fungo é baseada em genes que controlam os tipos de compatibilidade (mating types). Em fungos heterotálicos, a reprodução sexual envolve o encontro temporário de dois isolados fúngicos carregando mating types opostos e compatíveis, seguido por meiose e trocas de informações genéticas entre os indivíduos. O processo só é possível quando estes fungos, presentes numa mesma região geográfica, conseguem detectar a presença um do outro através de feromônios produzidos pelo mating type contrário (Zhan et al., 2002; Debuchy \& Tugeon, 2006). Análise de genes mating types, além de determinar a identidade sexual de populações de patógenos, é fundamental para predizer a ocorrência de reprodução sexual e assexual, possibilitando correlacionar esta ocorrência com a diversidade genética de uma população e o risco de evolução do patógeno (Conde-Ferráez et al., 2010, Gurung et al., 2011).

Locos mating type de ascomicetos filamentosos heterotálicos já estudados, incluindo M. musicola, M. fijiensis e M. graminicola, possuem uma de duas formas de sequências de nucleotídeos altamente dissimilares, nomeadas como idiomorfos, ocupando a mesma posição cromossomal no genoma (Debuchy \& Turgeon, 2006; Arzanlou et al., 2010; Conde-Ferráez et al., 2010; James et al., 2010). Por convenção, idiomorfos mating types de isolados complementares são chamados MAT1-1 e MAT1-2. Isolados MAT1-1 contêm um único gene (MAT1-1-1) codificando uma proteína com o domínio alpha, e isolados MAT1-2 um único gene (MAT1-2-1) codificando uma proteína contendo o domínio high-mobility group (HMG). Ambos os genes codificam fatores de transcrição controlando a via de transdução de sinais envolvida na identidade sexual e no desenvolvimento do ciclo sexual (Debuchy \& Tugeon, 2006; Arzanlou et al., 2010).

O idiomorfo de todos os membros heterotálicos dos Dothideomycetes foram caracterizados, até o momento, pela presença de um único gene, ao contrário de fungos homotálicos que apresentam ambos os genes (MAT1-1-1 e MAT1-2-1) no mesmo genoma (Arzanlou et al., 2010). Embora o tamanho do idiomorfo varie entre espécies de Mycosphaerella, os genes MAT1-1-1 e MAT1-2-1 possuem as mesmas orientações em relação aos seus cromossomos (Debuchy \& Turgeon, 2006; Goodwin 
et al., 2003; Waalwijk et al., 2002), e as sequências dos domínios alpha e HMG de cada idiomorfo mating type são relativamente conservadas entre M. musicola e $M$. fijiensis (Kim et al., 2013) (Figura 4).

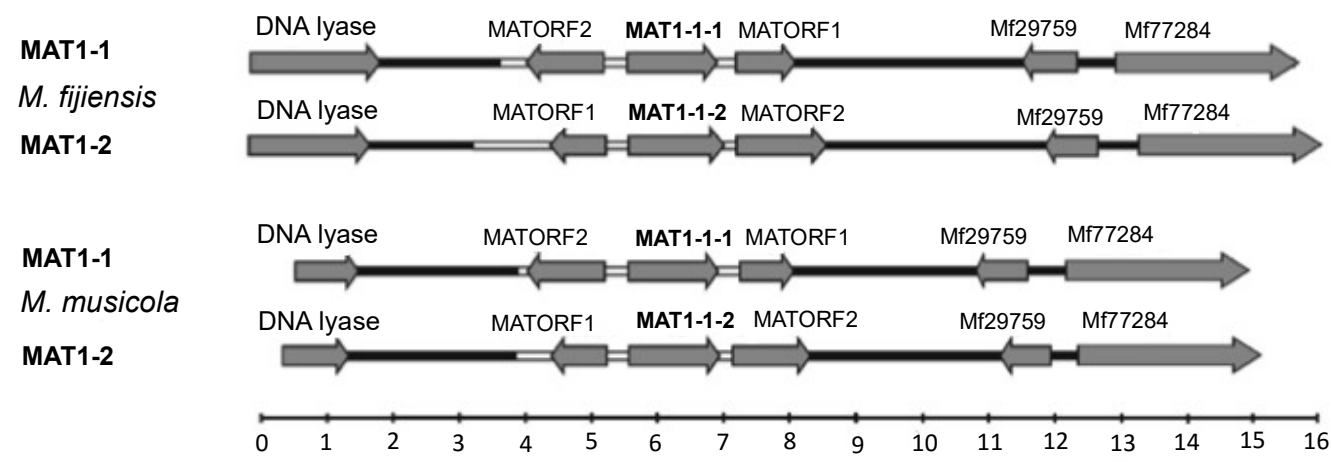

Figura 4. Organização dos locos mating types de M. musicola e M. fijiensis. Sequências dissimilares (idiomorfos) são indicados com linhas brancas, e sequências idênticas por linhas pretas. Modelos de genes previstos são indicados por setas. A escala mostra o tamanho em kilobases (Arzanlou et al., 2010).

$\mathrm{Na}$ maioria dos fungos patogênicos de plantas, a frequência dos idiomorfos MAT1-1 e MAT1-2 é igual ou quase igual (James et al., 2010). Para as espécies $M$. fijiensis e M. graminicola, os idiomorfos mating types já foram caracterizados e análises revelaram uma frequência de 1:1 de indivíduos com idiomorfos MAT1-1 e MAT1-2 (Conde-Ferráez et al., 2007; Gurung et al., 2011). Queiroz e colaboradores (2013) encontraram uma distribuição igual de mating types (1:1) para 129 isolados de seis diferentes estados no Brasil, indicando que recombinação genética ocorre em populações brasileiras de $M$. fijiensis. Alguns estudos também evidenciaram uma correlação entre virulência e idiomorfos mating types. Zhan e colaboradores (2007) avaliaram essa correlação em cinco populações de $M$. graminicola de quatro regiões geográficas (Austrália, Israel, Suíça e EUA). Os autores encontraram diferenças significativas na virulência entre isolados MAT1-1 e MAT1-2 causadores de 
septoriose do trigo. Apesar do aumento das pesquisas envolvendo a reprodução sexual dos fungos, até o momento, idiomorfos MAT1-1 e MAT1-2 dos locos mating types de M. musicola tem sido poucos caracterizados (Hayden et al., 2005).

Dado o importante papel da reprodução para a evolução de organismos vivos, análises da distribuição de mating types em populações de M. musicola podem contribuir para a compreensão da genética de populações, bem como da dinâmica e potencial evolucionário das populações deste patógeno.

\subsection{Diversidade genética}

\subsubsection{Análise da estrutura genética de populações}

Genética de populações refere-se ao estudo da variação genética espacial ou temporal em populações e dos mecanismos de perda e manutenção desta variabilidade (Nei, 1977), sendo capaz de fornecer a base para o entendimento das dinâmicas de estruturas genéticas e evolução. $\mathrm{O}$ destino de uma variedade genética, bem como da estrutura genética, que se refere à distribuição heterógena dos alelos e dos genótipos, no tempo e no espaço, podem ser influenciados pela biologia e circunstâncias a que o indivíduo foi submetido, incluindo o sucesso reprodutivo, mutação, deriva genética, tamanho populacional, migração e seleção natural (Hamrick, 1982; Sunnucks, 2000). Esses processos evolutivos e demográficos que afetam os indivíduos acabam por acumular efeitos nas populações, as quais, por sua vez, influenciam na especiação e na hierarquia taxonômica. Estudos da genética de populações investigam a relação entre esses processos evolutivos e padrões demográficos com variantes genéticas moleculares e permitem inferir sobre a biologia do organismo (Sunnucks, 2000).

$\mathrm{Na}$ análise da diversidade genética de populações, dois pontos principais estão envolvidos: quantificar os níveis de variabilidade dentro das populações e caracterizar o nível de estruturação genética entre populações (Hamrick, 1982). Para tanto, entre os principais parâmetros genéticos comumente adotados estão: índice de fixação, diversidade gênica de Nei, equilíbrio de Hardy-Weinberg (EHW), desequilíbrio de 
ligação, fluxo gênico, distância genética, número de alelos por loco e fluxo gênico entre outros.

A frequência gênica entre populações pode ser analisada através do índice de fixação ou estatística de F de Wrights (1965). Por meio desta, é possível determinar a diferenciação genética em três diferentes níveis: em nível populacional $\left(F_{I S}\right)$, na população total $\left(F_{I T}\right)$ e entre populações $\left(F_{S T}\right)$. As estatísticas de $\mathrm{F}$ foram inicialmente formuladas por Wrights (1965) para aplicação em populações com apenas dois alelos por loco, sendo posteriormente modificada por Nei (1977) para locos multialélicos.

Complementando a estatística de F, a análise da diversidade gênica em populações subdivididas também é utilizada para caracterizar a estrutura genética entre populações. Nei (1973) desenvolveu diferentes abordagens no estudo de diversidade genética de populações, mostrando que a diversidade gênica na população total $\left(H_{T}\right)$ pode ser distribuída dentro de seus componentes (intrasubpopulações ou intersubpopulações) $\left(H_{S}\right)$. Além de ser aplicável a populações subdivididas, essa estatística é independente do número de alelos por loco, tipo de reprodução (sexual ou assexual), ploidia e forças evolutivas (migração, seleção, mutação).

Embora seja um importante parâmetro para análise da diversidade genética, o número total de alelos por loco é altamente dependente do tamanho amostral. Para evitar viés comparativo, caso populações de diferentes tamanhos sejam contrastadas, as estimativas de riqueza alélica devem ser corrigidas por meio de métodos de padronização com base no menor tamanho amostral, como rarefação ou subamostragem randomizada repetida (Leberg, 2002; Allendorf \& Luikart, 2007).

O cálculo do fluxo gênico e da migração entre populações são possíveis de ser estimados de maneira indireta, por meio da estatística de $\mathrm{F}$ ou demais estatísticas correlatas, com razoável confiança (Chambers \& MacAvoy, 2000). Fluxo gênico é o movimento que ocorre entre populações que pode resultar em dois efeitos: em altos níveis, o fluxo gênico pode neutralizar a ação de seleção por redução da diferenciação genética entre populações; e em baixos níveis, pode afetar o polimorfismo dentro da população pela introdução e manutenção de novos alelos (Jain \& Bradshaw, 1966; Antonovics, 1968). Entretanto, distinguir entre esses dois efeitos ainda é motivo de 
controvérsia entre pesquisadores uma vez que, em muitas populações naturais, o fluxo gênico pode ser muito baixo para prevenir a diferenciação populacional mas ser alto suficiente para efetivamente manter alelos dentro da população (Hamrick, 1982). Para o estudo da estrutura populacional e migração que empregam estimativas da frequência alélica populacional, o número de alelos de microssatélites de alta diversidade atua como réplicas estatísticas dando mais confiabilidade para distinguir populações (Selkoe \& Toonem, 2006).

No equilíbrio de Hardy-Weinberg a frequência de um genótipo observado é comparada com a frequência esperada em uma população ideal: infinitamente grande, com cruzamento ao acaso e mutação, deriva genética ou migração ausentes. Logo, uma população em EHW apresenta uma frequência alélica constante ao longo de gerações, pela inexistência de fatores evolutivos atuantes (Yeh, 2000; Selkoe \& Toonem, 2006). Outrossim, os efeitos das forças evolutivas em muitas populações naturalmente grandes e panmíticas, são considerados mínimos ou se anulam, colocando-as em EHW (Freeland, 2005).

Desequilíbrio de ligação ocorre quando a frequência de determinada combinação entre dois locos numa população é maior do que a frequência esperada desses locos individualmente. Por estarem relativamente próximos, os genes segregam juntos e serão transmitidos aos pares para os descendentes. Mesmo se não ligados fisicamente em um cromossomo, os locos podem ser funcionalmente relacionados e sob a seleção, serem transmitidos aos pares. Desequilíbrio de ligação cria pseudo-replicações para as análises em que os locos são assumidos serem amostras independentes no genoma. Para evitar erro, um loco do par deve ser eliminado se um desequilíbrio significante for encontrado entre os locos (Selkoe \& Toonem, 2006).

Para reconstrução filogenética, estimativas das distâncias genéticas também são necessárias. De acordo com Goldstein \& Pollock (1997), uma boa medida de distância gênica é aquela em que o valor esperado aumenta linearmente com o tempo e que mostra baixa variância. A partir desses dados, métodos de agrupamento tem 
sido utilizados com o intuito de maximizar a similaridade dentro de grupo e a dissimilaridade entre grupos.

\subsubsection{Marcadores moleculares na análise da estrutura genética}

Diferentes genes e diferentes regiões do genoma apresentam características moleculares que fornecem informações em diferentes níveis da biologia da população e mostram sutis diferenças na história geneológica dos organismos (Selkoe \& Toonen, 2006). Um dos mais sensíveis sinais genéticos de mudanças moleculares no genoma são matrizes genotípicas comumente encontradas na forma de múltiplos locos microssatélites em amostras de indivíduos. Em espécies sexuadas, essas matrizes são reformuladas a cada geração e são úteis para a análise de processos evolutivos mais curtos e em menor escala como a relação intraespecífica (Sunnucks, 2000; Selkoe \& Toonen, 2006). Por meio de marcadores genéticos, análises rápidas através do acesso ao genótipo do indivíduo são possíveis e informações sobre a biologia de uma população e o processo evolutivo ao longo da vida do organismo podem ser analisados (Sunnucks, 2000).

Cada marcador apresenta características próprias e a escolha do marcador a ser utilizado depende dos objetivos da pesquisa. Marcadores moleculares como RAPD (Random Amplified Polymorphic DNA) (Moreira et al., 2003), AFLP (Amplified Fragment Length Polymorphism), RFLP (Restriction Fragment Length Polymorphism) (Carlier et al., 1996, Hayden et al., 2005) e microssatélites ou SSR (Simple Sequence Repeats) (Gurung et al., 2011) têm auxiliado a análise da genética estrutural populacional em escala local, regional e continental de diferentes espécies de Mycosphaerella. Gerber e colaboradores (2000) mostraram que 159 locos AFLP forneceram menor precisão para determinar diversidade que seis marcadores microssatélites polimórficos. Moreira e colaboradores (2003), utilizando a técnica RAPD, caracterizaram geneticamente 24 isolados de M. musicola de diferentes regiões do Brasil. A alta variabilidade genética observada foi atribuída às condições climáticas, reprodução sexuada e natureza heterotálica dos isolados. Similarmente, 
Montarroyos (2005), analisando a diversidade genética de $M$. musicola proveniente do estado de Pernambuco, não encontrou correlação entre a alta diversidade observada e as origens geográficas dos isolados.

Embora os marcadores moleculares tenham se tornado importantes ferramentas para a análise da estrutura genética em fungos, a escolha da técnica apropriada é fundamental para o sucesso da genética molecular na biologia populacional. Mesmo sendo multilocos, as técnicas de AFLP e RAPD não guardam a mesma resolução e o mesmo potencial de multilocos microssatélites. Molina e Kahl (2002) consideraram os marcadores microssatélites os mais eficientes para essa análise em espécies de Mycosphaerella e atualmente, é uma das técnicas mais empregadas para auxiliar na elucidação da variabilidade genética de M. musicola (Molina \& Kahl, 2004; Zapater et al., 2008; Gurung et al., 2011) .

Os microssatélites são grupos de sequências de DNA repetitivas que representam uma porção significativa do genoma de eucariotos e exibem características importantes para o rastreamento de regiões moleculares simples no genoma: são abundantes, codominantes e altamente polimórficos (Schlötterer, 1998; Selkoe \& Toonen, 2006). As razões por torná-los os mais populares e versáteis marcadores para aplicações ecológicas são devidas ao seu elevado conteúdo informativo, relacionado ao número e frequência de alelos detectados; e pela facilidade de genotipagem. Enquanto outros marcadores geram sequências que produzem um padrão único em gel, os SSR são facilmente identificados por possuírem alelos de diferentes tamanhos que podem ser distinguidos em gel de alta resolução e que permitem rápida genotipagem de muitos indivíduos em muitos locos (Selkoe \& Toonen, 2006). Além da análise de polimorfismos de SSR ser mais simples e econômica quando comparada a outras metodologias, ela demanda pequena quantidade de DNA, pode ser automatizada e permite uso de técnicas de fluorescência e multiplex (Semagn et al., 2006; Kalia et al., 2011).

Os microssatélites apresentam estrutura simples de repetição interna com unidades de repetições em tandem de 1 a 6 nucleotídeos (mono-, di-, tri-, tetra-, penta, hexa-nucleotídeos) encontradas em alta frequência no genoma nuclear de muitos 
taxa (Schlötterer, 1998; Selkoe \& Toonen, 2006). Os locos SSR variam no comprimento de 5 a 40 repetições, mas sequências maiores são possíveis. Repetições de dinucleotídeos, trinucleotídeos e tetranucleotídeos são as mais comumente encontradas em estudos de genética molecular. O DNA em torno do loco SSR é a região flanqueada que, geralmente, é conservada entre indivíduos da mesma espécie e algumas vezes entre diferentes espécies (Selkoe \& Toonen, 2006).

A variabilidade dos microssatélites resulta de qualquer ganho ou perda de unidades de repetições, sendo úteis para uma eficiente e acurada diferenciação molecular entre indivíduos e entre populações com estreita base genética e que podem ser rapidamente identificadas através de PCR (Schlötterer, 1998; Bahkali et al., 2012). Muitos microssatélites possuem alta taxa de mutação (entre $10^{-2}$ e $10^{-6}$ mutações por loco por geração, uma média de $5 \times 10^{-4}$ ), em geral de 10 a 100 vezes maior que em outras regiões no genoma. Por essa razão, altos níveis de diversidade alélica são gerados, fazendo com que os SSR sejam considerados sequências de alta taxa evolutiva e importantes para estudos genéticos de detecção de processos que ocorreram em um passado recente (10 a 100 gerações), como fluxo gênico ou estrutura clonal (Schlötterer, 2000; Selkoe \& Toonem, 2006).

\subsubsection{Diversidade genética de Mycosphaerella musicola}

A utilização de microssatélites permite descrever a demografia e história de organismos, estimar taxa de migração e distinguir seus efeitos de panmixia bem como avaliar o parentesco entre os indivíduos de forma detalhada. Do mesmo modo, oferece informações sobre o nível de variabilidade genética ocorrida em virtude de mutações e possível reprodução sexuada (Selkoe \& Toonem, 2006).

Juntamente com o nível de fluxo gênico em populações de patógenos, informações sobre variabilidade genética tem implicações no manejo de doenças em questões como o aumento da virulência, desenvolvimento de resistência a fungicidas e como essas características podem se disseminar entre populações. Níveis elevados de variabilidade genética em populações de fitopatógenos, como M. musicola, podem 
permitir a adaptação destas a diferentes ambientes e a genótipos de hospedeiras resistentes recém introduzidas (Churchill, 2011).

Marcadores microssatélites específicos para M. musicola foram identificados por Carlier e colaboradores (1994) por meio da construção de biblioteca genômica. Molina et al. (2001) e Zapater et al. (2008) também contribuíram na identificação de marcadores SSR para a análise da diversidade genética de populações de M. musicola. De acordo com Molina e Kahl (2001), são necessários cerca de nove marcadores SSR para diferenciar geneticamente indivíduos de M. musicola e M. fijiensis.

Hayden e outros (2003), ao analisarem a diversidade genética de populações de M. musicola em escala global, encontraram maior diversidade em populações da Indonésia, quando comparada às populações oriundas da África, América Latina e Austrália. Hayden e colaboradores (2005), ao estudarem a estrutura genética de populações de M. musicola provenientes da Austrália, relataram a ocorrência de restrito fluxo gênico em escala continental.

Embora de grande importância no Brasil e em todos as regiões produtoras de banana no mundo, análises da diversidade genética de populações de M. musicola ainda são escassas, sendo mais comuns em M. fijiensis (Perea et al., 2005; CondeFerráez et al., 2007; Queiroz et al., 2013) e em outras espécies do gênero, como $M$. graminicola (Gurung et al., 2011; Berraies et al., 2013).

Queiroz e colaboradores (2014) observaram alta variabilidade genética em populações de $M$. fijiensis amostradas de diferentes estados no Brasil, por meio de marcadores IRAP (Inter-Retrotransposon Amplified Polymorphism). Rivas e outros (2004) utilizaram marcadores SSR para avaliar o fluxo gênico e o processo de dispersão de $M$. fijiensis em uma escala continental: América Latina e regiões da África. Segundo os mesmos, baixos níveis de variabilidade genética foram encontrados em algumas regiões amostradas, mostrando que o efeito fundador acompanhou a recente invasão do patógeno em ambas as regiões, sugerindo uma propagação estocástica da doença em escala continental. Ao analisar a estrutura genética de $M$. fijiensis em Camarões e Costa Rica, áreas recém colonizadas pelo patógeno, Halkett e colaboradores (2010) encontraram baixa variabilidade genética 
em ambos os países e isolamento por distância das populações de Camarões. Os autores relataram a importância de eventos de dispersão a longas distâncias versus a dispersão gradual na formação de estruturas populacionais com considerável escala geográfica.

Considerando a relevância de M. musicola em cultivos de banana no Brasil, torna-se necessário uma maior compreensão da estrutura genética e distribuição do patógeno, uma vez que esse conhecimento contribui para o desenvolvimento de estratégias para o melhoramento da planta e o manejo da resistência à doença, bem como fornecendo informações para a busca de alternativas sustentáveis de controle da Sigatoka-amarela.

\subsection{Efetor LysM}

\subsubsection{Mycosphaerella graminicola em trigo}

O trigo (Triticum spp) é um dos principais cereais cultivados no mundo ocupando em tonelagem após o milho e antes do arroz (FAOSTAT, 2013). Septoriose está entre as principais doenças com importância global nos cultivos de cereais (Eyal, 1999). Ela é provocada por Mycosphaerella graminicola (Fuckel) Schröter (Zymoseptoria tritici) (anamorfo: Septoria tritici), patógeno que acomete cultivos de trigo em todas as regiões produtoras do grão. Atualmente é a doença foliar de maior importância na Europa, e muitas outras partes temperadas no mundo. Perdas causadas por manchas de $S$. tritici podem reduzir os cultivos de 30 a $50 \%$, provocando um considerável impacto econômico. A doença é mais comum em regiões com regime de chuvas durante o desenvolvimento do grão até a emergência da folha bandeira (última folha) (Eyal et al., 1987).

No Brasil, a região Sul é a maior produtora de trigo do país e também registra danos provocados por $S$. tritici, principalmente em áreas tritícolas com elevada precipitação pluvial e temperaturas que variam de 15 a $28^{\circ} \mathrm{C}$ durante o período de 
desenvolvimento da cultura. Entretanto, Stagonospora nodorum é o principal agente causador de danos nos cultivos de trigo no Brasil (Prestes, 2011).

\subsubsection{Infecção de Mycosphaerella graminicola no trigo}

Fungos fitopatógenos podem ser classificados em três diferentes categorias baseadas na forma nutricional durante a interação com a hospedeira. Os necrotróficos, são caracterizados por estimularem a morte do tecido da hospedeira e se alimentarem exclusivamente destes nutrientes. Por outro lado, fungos biotróficos carecem do tecido vivo da hospedeira para o fornecimento dos nutrientes necessários. Estes podem ser controlados pela morte celular programada, referida como reação de hipersensibilidade (RH). Entre os dois extremos, necrotróficos e biotróficos, estão os

patógenos hemibiotróficos que passam uma significante parte do seu ciclo de infecção alimentando-se como biotróficos, antes de uma repentina mudança para a forma necrotrófica provocado pelo colapso do tecido da hospedeira (Luttrell, 1974; Keon et al., 2007; Dean et al., 2012).

M. graminicola apresenta diferenças na habilidade para infectar e obter nutrientes, comparado a outros fungos patogênicos necrotróficos e biotróficos (Goodwin et al., 2011). A infecção de folhas de trigo pelo patógeno é associada com longos períodos de latência antes do aparecimentos dos primeiros sintomas visíveis da doença, que podem se estender por várias semanas após a inoculação (Keon et al., 2007; Dean et al., 2012). Por essa razão, M. graminicola e espécies relacionadas têm sido referidas como hemibiotróficas, baseado no fato de que a fase de crescimento assintomático envolve o fungo adquirindo nutrientes suficientes do tecido vivo e, então, alimentando-se biotroficamente (Luttrell, 1974; Dean et al., 2012).

O ciclo de infecção de M. graminicola é descrito em cinco fases distintas. A penetração do patógeno ocorre via estômatos três dias após a inoculação. O fungo vive assintomaticamente por até 10 a 14 dias, tempo em que se inicia a colonização da cavidade subestomática e das células do mesófilo da folha em torno do apoplasto. A 
alimentação necrotrófica inicia-se juntamente com o aparecimentos dos primeiros sintomas de colapso do tecido da hospedeira, e a partir desse ponto, o crescimento do fungo se torna mais rápido. Nessa fase, também ocorre o desenvolvimento de estruturas de esporulação assexual, os picnídios, na superfície foliar necrosada. Através destes, esporos do fungo reemerge na forma de cirrhu, uma estrutura mucilaginosa que guarda os picnidiósporos que são propagados por gotas de chuvas para outras folhas da planta. Em contraste com muitos outros patógenos fúngicos de plantas, M. graminicola não é conhecido por desenvolver estruturas especializadas de penetração ou de alimentação e permanece no apoplasto durante todo o ciclo de infecção (Kema et al., 1996; Keon et al., 2007; Dean et al., 2012).

Os sintomas nas folhas infectadas de plantas de trigo suscetíveis manifestamse pelo aparecimento abrupto de lesões cloróticas e necróticas dentro das quais o fungo esporula. Essa rápida transição e manifestação dos sintomas sugere que as lesões possam ser disparada pelo fungo via produção de toxina (Kema et al., 1996). Entretanto, pouco se sabe sobre a resposta da hospedeira associada com essa súbita transição e nem mesmo sobre as adaptações específicas feitas pelo patógeno que resulta na superação ou tolerância dessas modificações (Keon et al., 2007; Dean et al., 2012).

Muitos fungos patogênicos de plantas importantes apresentam estilo de vida semelhantes ao de M. graminicola. Análises filogenéticas colocaram M. graminicola entre outros importante patógenos causadores de manchas foliares em plantas com significantes impactos na agricultura, incluindo M. musicola e M. fijiensis em bananeiras e Cercosporoa zeae-maydis em milho (Goodwin, 2004). Estes patógenos mostram semelhanças no processo de infecção, como penetração via estômatos, longo período de colonização assintomática, falta de estrutura de alimentação especializada e formação de lesões cloróticas e necróticas dentro das quais os patógenos esporulam (Keon et al., 2007; Dean et al., 2012).

Assim como outras espécies de Mycosphaerella, M. graminicola apresenta propagação sexual via ascósporos e assexual via picnidiósporos, dispersos pelo vento e respingos de água, respectivamente (Kema et al., 1996). A forma assexual contribui 
para o desenvolvimento da doença durante a estação de crescimento, enquanto o teleomorfo é a fonte primária de inóculo para a emergência do trigo no outono (Shaw \& Royle, 1993; Eriksen \& Munk, 2003).

\subsubsection{Imunidade desencadeada por PAMPs (PTI) e efetores (ETI)}

Durante a interação de alguns fungos fitopatogênicos e seus hospedeiros, como Cladosporum fulvum em folhas de tomate (Solanum lycopersicum), a quitina, um dos principais componentes da parede celular do patógeno, parece sofrer a ação de quitinases liberadas pela planta (Bolton et al., 2008). Os fragmentos de quitina são oligossacarídeos classificados como padrões moleculares associados ao patógeno (PAMPs - pathogen-associated molecular patterns) (Jones \& Dangl, 2006). Estes, incluindo proteínas e outras moléculas, são reconhecidos pelas células das plantas através dos receptores de reconhecimento padrão (PRRs - pattern recogniton receptors), desencadeando a defesa basal, primeira linha de defesa da planta, nomeada como imunidade desencadeada por PAMP (PTI - PAMP-triggered immunity) (Bolton et al., 2008; Boller \& He, 2009; de Jonge et al., 2010; Marshall et al., 2011). Os patógenos, por sua vez, possuem a capacidade de suprimir o PTI, lançando de efetores especializados, durante uma fase específica da interação com a planta.

Os efetores são proteínas relativamente pequenas, com a habilidade de interferir com o PTI (de Jonge et al., 2010; Marshall et al., 2011; Akcapinar et al., 2015). Entretanto, tal fato levou as plantas à evolução de receptores adicionais, com sítios de ligação a nucleotídeo e região rica em leucina (NB-LRR - nucleotide-binding site leucine-rich repeat). Estes são codificados por genes $R$ cujos produtos efetivamente reconhecem os efetores, por meio da interação gene a gene, e ativam uma segunda linha de defesa, para impedir a ação dos mesmos, descrita como imunidade disparada por efetores (ETI - effector-triggered immunity) (Boller \& He, 2009). O ETI resulta em resistência à doença e, usualmente, numa resposta de hipersensibilidade e morte celular. O início de novas respostas de defesa da planta ao 
ataque do patógeno impede a sua progressão, exercendo uma pressão seletiva para que ele se torne cada vez mais especializado (Jones \& Dangl, 2006). Consequentemente, níveis de imunidade subsequentes também podem ser suprimidos através de funções efetoras do patógeno, ilustrando a dinâmica coevolução entre patógenos e plantas, dado o modelo "zigzag" (Jones \& Dangl, 2006) em que a seleção natural favorece novos alelos dos genes $R$ da planta que reconhecem novos efetores fúngicos (Figura 5). Embora a resistência a M. graminicola siga uma relação gene-agene, o patossistema não se enquadra no modelo "zigzag". A resposta de hipersensibilidade não parece parte do ETI, embora os produtos dos genes $R$ reconheçam os produtos dos genes Avr (avirulência) ainda não caracterizados, que resultam em imunidade da planta ao patógeno. Ainda não se sabe como o mecanismo de resistência da planta responde a M. graminicola (Orton, 2012; Lee et al., 2014).

\subsubsection{Genes efetores LysM}

A identificação e análise molecular e funcional de genes efetores enriquecem a compreensão sobre a virulência do patógeno e o sistema de defesa da planta. Igualmente, contribuem para elucidar os mecanismos envolvidos na interação patógeno x planta, fator fundamental para o desenvolvimento de novas estratégias de controle de doenças de plantas.

Trabalhos recentes identificaram uma nova proteína efetora extracelular (Ecp6) que é abundantemente secretada por todos os isolados de C. fulvum durante a infecção em folhas de tomate, que se mostrou necessária para a virulência completa (Bolton et al., 2008; de Jonge et al., 2010). Até agora, é a única proteína efetora de $C$. fulvum com ortólogos em muitas outras espécies fúngicas (Bolton et al., 2008, de Jonge et al., 2010). A proteína Ecp6 possui três domínios LysM que, em geral, são implicados na ligação de carboidratos, incluindo quitina (de Jonge et al., 2009, Wong et al., 2015; Akcapinar et al., 2015). Ela está envolvida na captura de fragmentos de quitina que são liberados da parede celular do fungo durante a infecção, que atuam como PAMPs evitando a elicitação da resposta de defesa da planta (Bolton et al., 
2008; de Jonge et al., 2010; Akcapinar et al., 2015).

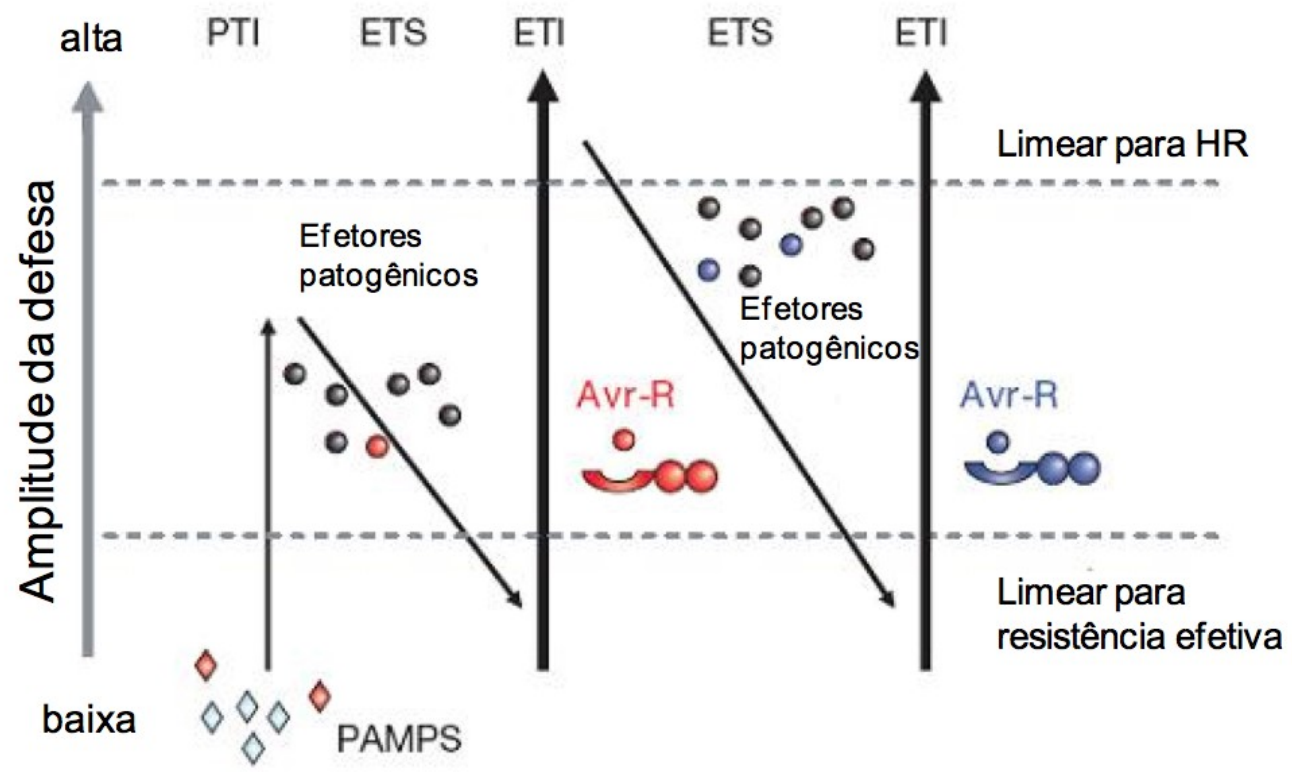

Figura 5. Modelo "zigzag" ilustrando as etapas do desenvolvimento do sistema imunológico da planta durante a infecção. Na primeira fase, as plantas detectam a população microbiana (PAMPs, diamantes vermelhos), desencadeando uma resposta de imunidade (PTI). Na segunda fase, patógenos liberam efetores que interferem com a PTI, desencadeando a susceptibilidade por efetores (ETS). Na terceira fase, um efetor (indicado na figura em vermelho, Avr) é reconhecido pelas proteínas NB-LRR, ativando a imunidade desencadeada por efetores (ETI), uma versão ampliada de PTI que muitas vezes induz a resposta de hipersensibilidade (HR). Na quarta fase, novos efetores surgem através do fluxo horizontal de genes (em azul), ajudando os patógenos a suprimir o ETI. A seleção por parte das plantas de novos alelos de proteínas NB-LRR, que podem reconhecer um dos efetores recém adquiridos, dispara novamente a ETI. Fonte: Jones \& Dangl, 2006.

Apesar de serem relativamente escassos os trabalhos que identificam proteínas efetoras no gênero Mycosphaerella, a presença de Ecp6 contendo domínio LysM já foi descrita em M. graminicola (Marshall et al., 2011) e recentemente em M. musicola 
(Passos et al., 2013). Marshall e colaboradores (2011) analisando homólogos de Ecp6 de C. fulvum em M. graminicola, verificaram que dois (Mg3LysM, Mg1LysM) de três genes que potencialmente codificam para proteínas efetoras foram altamente expressos, traduzindo proteínas especialmente durante a fase assintomática de infecção no trigo. Na fase de necrose da folha, as expressões dos genes foram baixas, indicando um controle temporal da expressão de efetores de virulência LysM durante a patogênese da planta. Atualmente, o grupo investiga quais fatores (planta específica ou outros sinais químicos) controlam a expressão de efetores MgLysM, utilizando isolados transgênicos com construções contendo promotor gene - repórter e investigam a influência do efetor LysM na colonização do patógeno.

Para M. musicola, Passos e colaboradores (2013) analisaram o transcritoma da folha de Musa acuminata durante a interação in vivo com o fungo, e identificaram homólogos da proteína efetora Ecp6 entre os transcritos. Apesar da identificação dos genes efetores candidatos, sua função ainda precisa ser confirmada experimentalmente por superexpressão, interrupção ou silenciamento gênico em isolados fúngicos, e subsequente análise da (a)virulência em plantas hospedeiras (Stergiopoulos \& Wit, 2009).

\subsubsection{Receptores de efetores em plantas}

Alguns receptores na planta, para quitina, tem sido caracterizados. O receptor CEBiP (chitin oligosaccharide elicitor binding protein), uma proteína com alta afinidade a quitina, foi isolado da membrana plasmática de células de arroz (Oryza sativa) (Kaku et al., 2006). Este receptor, RLP (receptor-like protein), contém um domínio LysM extracelular, que parece possuir importante papel na percepção de oligossacarídeos de quitina. Entretanto, para iniciar a subsequente sinalização de defesa, um domínio intracelular de sinalização é necessário, sugerindo que componentes adicionais sejam requeridos para tal (Thomma et al., 2011, Lee et al., 2014). Um potencial co-receptor de CEBiP, recentemente identificado em Arabidopsis é o Os-CERK1 (LysM- containing chitin elicitor receptor kinase-1) que, 
similar ao CEBiP, é requerido para sinalização da quitina (Shimizu et al., 2010; Lee et al., 2014). Assim, foram identificados dois tipos de (glico)proteínas que são cruciais para a percepção e transdução de elicitores de oligossacarídeos de quitina em arroz e Arabidopsis, respectivamente (Shimizu et al., 2010). Na presença destes receptores, o PTI é desencadeado. Este PTI não é específico (Pitzschke et al., 2009), já que o oligossacarídeo reconhecido pelo receptor da planta, que neste caso é uma quitina, é comum a vários patógenos fúngicos. A partir do PTI, a planta desencadeia sinais envolvidos na defesa como: deposição de celulose na parede celular, fechamento dos estômatos e síntese de fitoalexinas (Pitzschke et al., 2009; Lee et al., 2014). Reconhecendo esses sinais, o patógeno induz a produção de proteínas efetoras, sob a expressão de genes Ecp6. Entretanto, pouco se sabe dos sinais em plantas que possam induzir a produção de efetores em patógenos como M. musicola, M. fijiensis e $M$. graminicola.

Dentre as espécies de Mycosphaerella atualmente em estudo, M. graminicola é a mais bem caracterizada sendo, juntamente com sua hospedeira, um modelo de estudo para outros patossistemas. Análises da interação M. graminicola x trigo permitem investigar fatores cruciais na interação planta-patógeno, ou seja, como e em que medida o patógeno invasor é capaz de responder a mudanças na fisiologia da hospedeira durantes estágios específicos da infecção (Keon et al., 2007; Dean et al., 2012). 


\section{Capítulo 2 - Análise da diversidade genética e recombinação sexual em populações de Mycosphaerella musicola}

\section{Resumo}

Variedades comerciais de banana (Musa spp.) são cultivadas em mais de 100 países, gerando uma produção anual de aproximadamente 100 milhões de toneladas. O Brasil ocupa a quinta posição no ranking de produção do fruto, ficando atrás da Índia, China, Filipinas e Equador. Mycosphaerella musicola, agente causal de Sigatoka-amarela, ocorre em todas as áreas produtoras de banana no país. Embora em maior ocorrência que Mycosphaerella fijiensis, agente causal de Sigatoka-negra, M. musicola é menos agressivo e análises da diversidade genética e estrutura populacional do fungo têm sido limitadas. Os objetivos do presente estudo foram verificar a ocorrência de recombinação sexual em populações de M. musicola de 13 diferentes zonas agroecológicas do Brasil, baseado na análise de idiomorfos mating types, bem como analisar a diversidade genética das populações com base em 19 locos microssatélites. Com exceção de isolados coletados em uma área do Distrito Federal, as populações mostraram proporção de 1:1 de genes MAT1-1-1 e MAT1-2-1, indicando a ocorrência de recombinação sexual. Alto nível de variabilidade genética foi observada entre indivíduos dentro das populações, fato que pode ser resultante da recombinação sexual, que contribui para a geração de novos alelos e para o aumento da variabilidade dentro das populações. Um considerável número de migrantes entre populações de diferentes estados foi observado. Isso indica que ações antrópicas como transporte de germoplasma contaminado podem contribuir para o fluxo gênico e a homogeneização das populações, considerando que a dispersão por ascósporos por grandes distâncias seja incomum. A alta fração clonal nas populações sugere que a reprodução assexual emprega um importante papel na estrutura genética, apoiando evidências da dispersão por conídios dentro de bananais. 


\subsection{Introdução}

Banana (Musa spp.) é atualmente um dos frutos mais consumidos mundialmente com cultivo em mais de 100 países e a produção assumindo importante papel social e econômico em muitos países em desenvolvimento. O Brasil é o quinto maior produtor com uma média anual de consumo por pessoa de $31 \mathrm{~kg}$ (FAOSTAT, 2011). Myscophaerella musicola (R. Leach ex. J. L. Mulder 1979) (Anamorfo: Pseudocercospora musae Zimm. Deighton), agente causador de Sigatoka-amarela, é um dos principais patógenos causadores de danos na produção do fruto, juntamente com Mycosphaerella fijiensis (Morelet) (anamorfo: Pseudocercospora fijiensis), causador de Sigatoka-Negra. No Brasil, a Sigatoka-amarela foi constatada pela primeira vez em 1944 no estado do Amazonas (Kimati e Galli, 1980) e atualmente está presente em todos os estados brasileiros. Os principais sintomas provocados pelo patógeno são: manchas necróticas que causam a perdas da área fotossintética e consequentemente, provocam a redução do número de cachos e tamanho dos frutos (Cordeiro \& Matos, 2003), levando à significativas perdas na produção e importantes prejuízos econômicos. Embora mais distribuído que M. fijiensis, M. musicola é considerado menos agressivo e estudos sobre a sua diversidade genética e a estrutura populacional ainda são reduzidos.

Recombinação sexual em fungos, como em M. musicola, é um processo frequente podendo ocorrer um ou vários ciclos sexuais durante a estação de crescimento. Juntamente com outros fatores como: deriva genética, mutação e parassexualidade (Brent \& Hollomon, 2007), a recombinação sexual é um gerador de variabilidade genética. Considerando que as cultivares economicamente mais importantes são poliplóides estéreis com resistência ausente para muitos estresses bióticos, medidas de controle são dependentes de aplicações de fungicidas. Em decorrência disso, não apenas o custo da produção é elevado, mas também causa significantes impactos negativos ao ambiente e seleção de patógenos resistentes a fungicidas. Neste contexto, análises da diversidade genética de populações de patógenos, juntamente com monitoramento de resistência a fungicidas são de 
fundamental importância para o desenvolvimento e otimização de estratégias de controle de patógenos que considera o tempo e frequência de aplicação, e a mistura ou alternância de agroquímicos como estratégias anti-resistência.

Uma série de abordagens moleculares tem sido empregadas para análises de estrutura genética de populações de diferentes espécies de Mycosphaerella, em escala local, regional e continental. Marcadores informativos incluem genes mating types, RAPD (Random Amplified Polymorphic DNA) (Moreira et al., 2003), AFLP (Amplified Fragment Length Polymorphism), RFLP (Restriction Fragment Length Polymorphism) (Carlier et al., 1996, Hayden et al., 2005), ERIC-PCR (Silva et al., 2014) e microssatélites ou SSR (Simple Sequence Repeats) (Gurung et al., 2011).

Os locos mating types de ascomicetos filamentosos heterotálicos, incluindo membros do gênero Mycosphaerella, possuem uma de duas formas de sequências dissimilares (conhecidas como idiomorfos) ocupando a mesma posição cromossomal no genoma (Conde-Ferráez et al., 2007; Arzanlou et al., 2010). Esses idiomorfos mating types em isolados heterotálicos complementares de uma espécie particular são chamados MAT1-1 e MAT1-2. Isolados do primeiro tipo contém um único gene (MAT1-1-1) codificando uma proteína com o domínio alpha. Os últimos isolados possuem um único gene (MAT1-2-1) codificando uma proteína com o domínio HMG (High-Mobility Group). Ambos os genes codificam fatores de transcrição que regulam o ciclo sexual através do controle da via de transdução de sinal envolvida na identidade mating (Wirsel et al., 1998; Nolting \& Poggeler, 2006; Arzanlou et al., 2010). Ao contrário de outras espécies de Mycosphaerella como M. fijiensis e $M$. graminicola (Zymoseptoria tritici), os idiomorfos mating types de M. musicola foram pouco caracterizados. Entretanto, como estas regiões do genoma parecem ser altamente conservadas entre espécies estreitamente relacionadas no gênero (Arzanlou et al., 2010; Kim et al., 2013), primers desenvolvidos para a caracterização dos genes mating types de $M$. fijiensis podem ser empregados para M. musicola. Para $M$. fijiensis (Conde-Ferráez et al., 2007; Queiroz et al., 2013) e M. graminicola (Gurung et al., 2011), análises da região mating type revelaram uma frequência de 1:1 de MAT1-1 e MAT1-2. 
Análises de diversidade genética com diferentes marcadores moleculares têm sido conduzidas em populações de M. musicola amostradas de diferentes países. Moreira e colaboradores (2003), utilizando RAPD, observaram diversidade genética entre 24 isolados de M. musicola de diferentes regiões geográficas no Brasil. Hayden e colaboradores (2003), avaliando a diversidade genética global entre populações de M. musicola, com base em RFLP, afirmaram que a estrutura genética populacional deste fungo é desconhecida e verificaram uma maior diversidade de isolados provenientes da Indonésia, quando comparados aos da América Latina, África, Caribe e Austrália. Ao analisar a estrutura genética de M. musicola na Austrália, Hayden e colaboradores (2005) sugeriram um reduzido fluxo gênico em escala continental.

Marcadores microssatélites são considerados apropriados para a análise da biologia e genética de populações (Selkoe \& Toonen, 2006). Esses locos SSR são codominantes, robustos, altamente polimórficos e fáceis para avaliar quando comparados com outras metodologias (Semagn et al., 2006). A aplicação de marcadores SSR para a caracterização de $M$. musicola tem sido limitada (Molina et al., 2001; Zapater et al., 2008), mas esses marcadores podem ser usados para estimar a diversidade genética dentro e entre populações de estados brasileiros. Nesse sentido, conhecer a diversidade de $M$. musicola de diferentes regiões pode contribuir com estratégias de manejo da doença e com programas de melhoramento genético da bananeira.

Os objetivos do trabalho foram verificar a ocorrência de recombinação sexual em populações de M. musicola oriundas do Distrito Federal e entorno e dos estados da Bahia, Minas Gerais e Rio Grande do Norte, com base nas análises das frequências de idiomorfos MAT1-1 e MAT1-2 em isolados; e analisar a diversidade genética dentro e entre as populações dos diferentes estados com base em marcadores SSR. As análises genéticas dos dados foram realizadas para testar tanto o equilíbrio genético quanto a estrutura genética das populações. Os resultados são discutidos em relação aos processos de dispersão e recombinação genética em populações de $M$. musicola em áreas de produção de banana no Brasil. 


\subsection{Material e Métodos}

\subsubsection{Coletas e isolamento de M. musicola}

As coletas de M. musicola foram realizadas em um total de 13 zonas agroecológicas produtoras de banana no Brasil, separadas entre si de 22 a $1.900 \mathrm{~km}$, distribuídas no Distrito Federal (DF) e entorno e nos estados da Bahia (BA), Minas Gerais (MG) e Rio Grande do Norte (RN) (Figura 6). Os isolados foram coletados de folhas de bananeiras mostrando sintomas típicos de Sigatoka-amarela, de diferentes genótipos suscetíveis de Musa, cujo sistema de manejo da doença foi baseado na aplicação de fungicidas protetores e sistêmicos (Tabela 1). Em cada localidade, dentro de uma área de aproximadamente $50 \mathrm{~m}^{2}$, cinco bananeiras foram selecionadas, uma em cada extremidade e uma na região central da área. Duas folhas mostrando sintomas foram selecionadas por planta e aproximadamente $20 \mathrm{~cm}^{2}$ de cada extremidade por folha, foram removidos (Figura 7). O material passou por limpeza superficial com água corrente, álcool (75\%) e água destilada, nesta ordem. As lesões foram recortadas e incubadas em câmara úmida (placas de Petri com papel filtro) por $48 \mathrm{~h}$ e então, foi observado sob estereoscópio para verificar o aparecimento de esporodóquio. Destes, os conídios foram transferidos assepticamente para uma lâmina contendo blocos de meio ágar e subsequentemente para placas com meio V8 (500 ml: $9 \mathrm{~g}$ de Ágar, $1 \mathrm{~g}$ de $\mathrm{CaCO}_{3}, 50 \mathrm{ml}$ de V8, $450 \mathrm{ml}$ de água destilada e 0,167 $\mathrm{g}$ de cloranfenicol), para garantir isolados monospóricos de M. musicola (Figura 8). Todas as culturas foram preservadas em água destilada e papel filtro. 


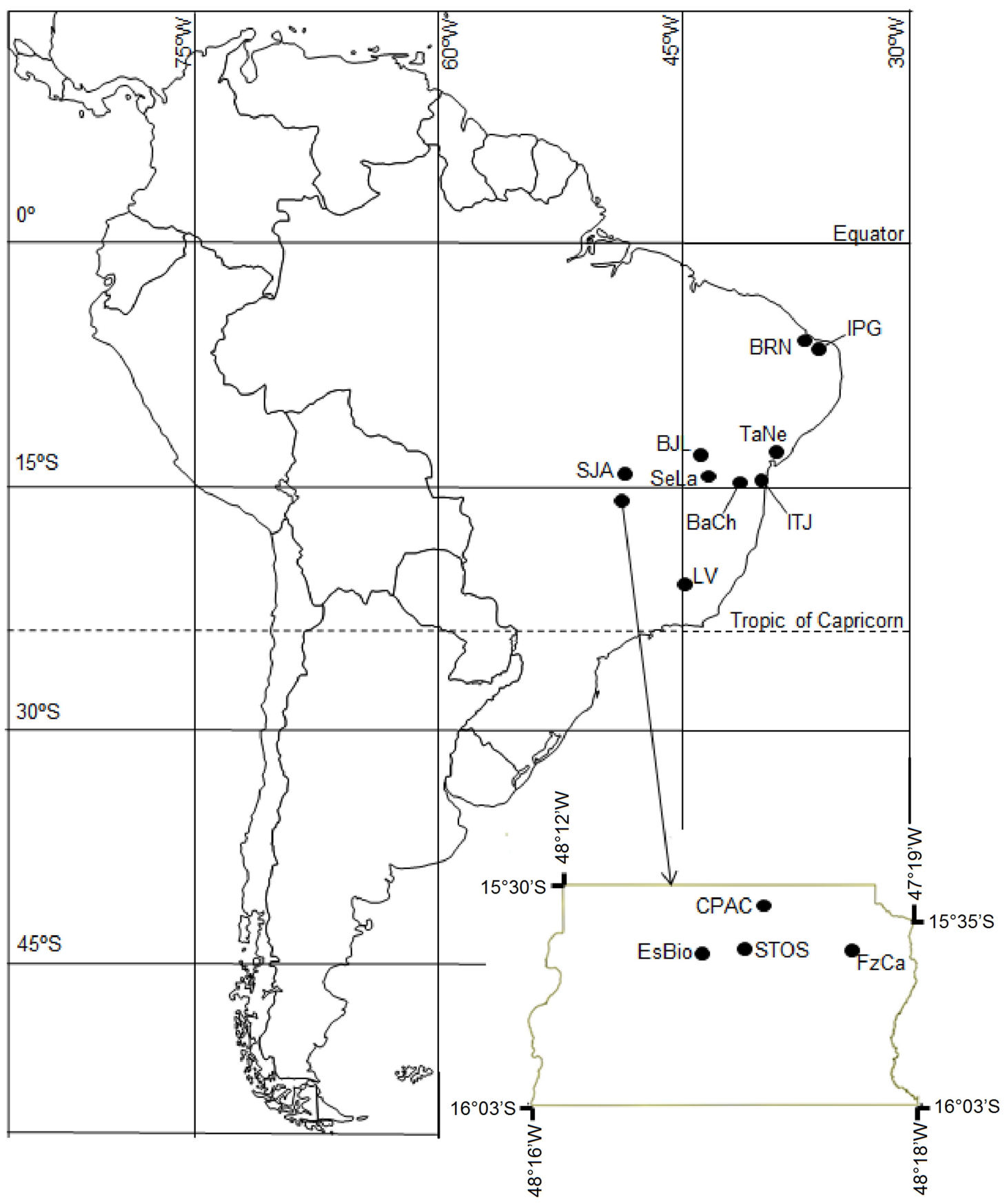

Figura 6. Distribuição geográfica dos isolados de Mycosphaerella musicola coletados em zonas produtoras de banana no Brasil. Distrito Federal e entorno: EsBio - Estação biológica; CPAC - Embrapa Cerrados; FzCa - Fazenda Canaã ; SJA - São João da Aliança; STOS Fazenda Santos. Bahia: BJL - Bom Jesus da Lapa; TaNe - Tancredo Neves; SeLa_ Sebastião Laranjeiras; ITJ - Itajuípe; BaCh - Barra do Choça. Minas Gerais: LV - Lavras. Rio Grande do Norte: IPG - Ipanguaçu; BRN - Baraúna. 
Tabela 1. Origem dos isolados de Mycosphaerella musicola.

\begin{tabular}{|c|c|c|c|}
\hline \multirow{3}{*}{$\begin{array}{c}\text { Localidade } \\
\text { Distrito Federal e entorno } \\
\text { 1. Estacão Biológica - UnB (EsBio) }\end{array}$} & \multicolumn{2}{|c|}{$\begin{array}{l}\text { Variedades } / \mathbf{n}^{\circ} \\
\text { de isolados }\end{array}$} & \multirow{2}{*}{$\begin{array}{c}\text { Total de isolados } \\
\text { (119) }\end{array}$} \\
\hline & 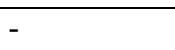 & & \\
\hline & Prata & $(25)$ & 25 \\
\hline \multirow[t]{5}{*}{ 2. Embrapa Cerrados - Planaltina (CPAC) } & Phia17 & (4) & \multirow[t]{5}{*}{22} \\
\hline & Phia02 & (4) & \\
\hline & $\begin{array}{l}\text { Maravilha } \\
\text { Thap Maeu }\end{array}$ & $\begin{array}{l}(4) \\
(4)\end{array}$ & \\
\hline & Prata comum & & \\
\hline & Grande Naine & & \\
\hline \multirow{2}{*}{$\begin{array}{l}\text { 3. Núcleo Rural Rio Preto - Fazenda Canaã } \\
\text { (FzCa) }\end{array}$} & Prata & (20) & \multirow[t]{2}{*}{36} \\
\hline & Nanica & (16) & \\
\hline \multirow{3}{*}{$\begin{array}{l}\text { 4. Água Fria de Goiás - São João da Aliança } \\
\text { (SJA) }\end{array}$} & Prata & (6) & \multirow[t]{2}{*}{13} \\
\hline & Nanica & (7) & \\
\hline & & & \multirow{3}{*}{23} \\
\hline \multirow{2}{*}{$\begin{array}{l}\text { 5. Núcleo Rural Sobradinho } 1 \text { - Fazenda } \\
\text { Santos (STOS) }\end{array}$} & Prata & (18) & \\
\hline & Nanica & (5) & \\
\hline Bahia & - & & (51) \\
\hline \multirow{5}{*}{ 6. Bom Jesus da Lapa (BJL) } & Terra & (1) & \multirow{5}{*}{21} \\
\hline & Maça & (2) & \\
\hline & Pavocan & (5) & \\
\hline & Prata comum & & \\
\hline & Grand Naine & (8) & \\
\hline \multirow{4}{*}{ 7. Tancredo Neves ( $\mathrm{TaNe})$} & Terra & (5) & \multirow{4}{*}{14} \\
\hline & Maça & (1) & \\
\hline & Pavocan & (2) & \\
\hline & Prata comum & & \\
\hline \multirow{2}{*}{ 8. Sebastião Laranjeiras (SeLa) } & Prata anã & (6) & 6 \\
\hline & Maça & (1) & \multirow[t]{2}{*}{5} \\
\hline 9. Itajuípe (ITJ) & Prata comum & (4) & \\
\hline \multirow{3}{*}{ 10. Barra do Choça (BaCh) } & & (3) & \multirow[t]{3}{*}{5} \\
\hline & Nanicão & (1) & \\
\hline & Prata anã & (1) & \\
\hline Minas Gerais & - & & (9) \\
\hline \multirow[t]{3}{*}{ 11. Lavras (LV) } & Maça & (4) & \multirow[t]{3}{*}{9} \\
\hline & Prata anã & (3) & \\
\hline & & & \\
\hline Rio Grande do Norte & - & & (8) \\
\hline 12. Ipanguaçu (IPG) & Maça/Leite & (3) & 3 \\
\hline 13. Baraúna (BRN) & Pavocan & (5) & 5 \\
\hline Total & - & & 187 \\
\hline
\end{tabular}



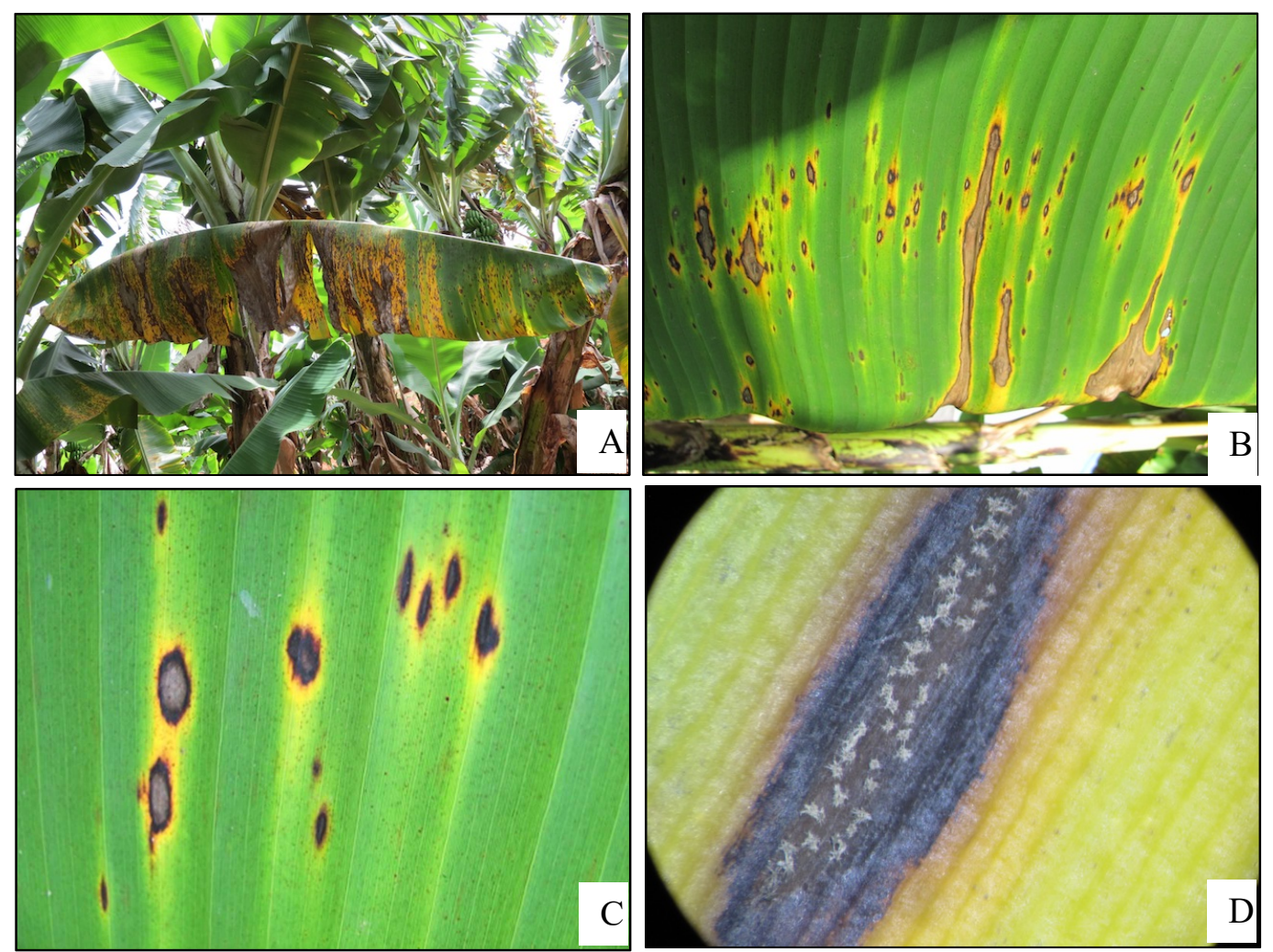

Figura 7. Sintomas típicos de Sigatoka-amarela. A- Cultivares de banana no Distrito Federal; B- Regiões necróticas causando redução da área foliar; C- Lesões necróticas envoltas por halos amarelos; D- Formação de esporodóquios no centro das lesões. 

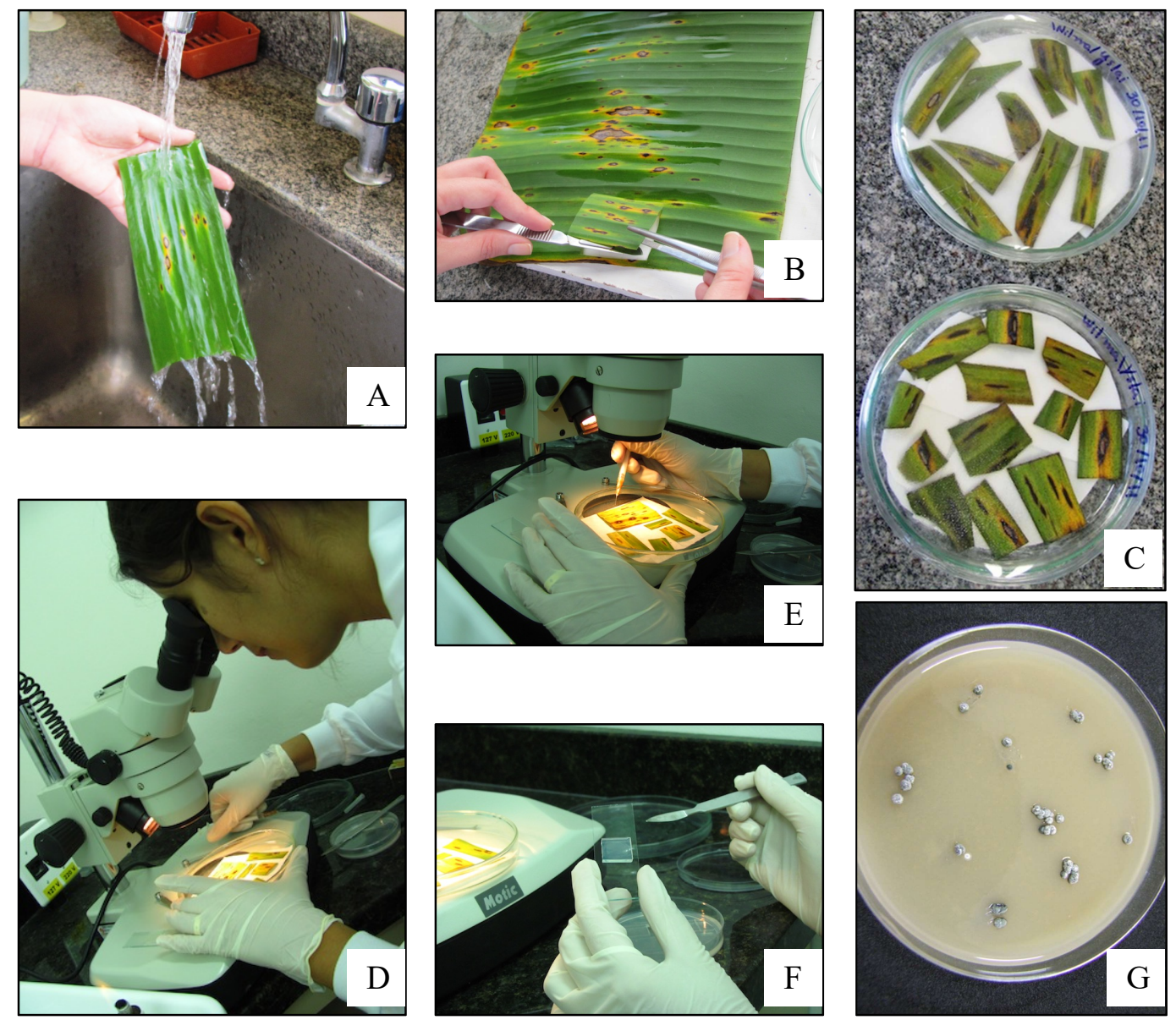

Figura 8. Etapas do isolamento de Mycosphaerella musicola de folhas de bananeira apresentando sintomas de Sigatoka-amarela. A, B e C- Assepsia, seleção de lesões e preparo de câmara úmida, respectivamente. D, E e F - Seleção de conídios a partir de esporodóquios no centro das lesões. G- Colônias monospóricas de M. musicola após 10 dias de crescimento. 


\subsubsection{Extração de DNA}

O DNA genômico foi extraído do micélio de isolados de M. musicola cultivados em placas de Petri com meio V8, por aproximadamente 30 dias, a $25^{\circ} \mathrm{C}$ e fotoperíodo de 12 horas, seguindo o protocolo de extração Doyle \& Doyle (1987) com algumas modificações. O micélio de cada isolado foi raspado da placa com auxílio de bisturi e colocado em cadinho para maceração com $\mathrm{N}_{2}$ líquido. Os materiais resultantes das macerações foram transferidos para tubos Eppendorfs de 2 $\mathrm{mL}$ onde adicionou-se $800 \mu \mathrm{L}$ da solução de tampão de extração (CTAB a 10\%, NaCl a $5 \mathrm{M}$, Tris $\mathrm{HCl}$ a $1 \mathrm{M}, \mathrm{pH}$, EDTA a 0,5 M, ß-mercaptoetanol, PVP polivinilpirrolidona, água ultra-pura) pré aquecida a $65^{\circ} \mathrm{C}$. Após a homogeneização por 5 minutos, os tubos foram incubados em banho-maria a $65^{\circ} \mathrm{C}$ por 45 minutos (homogeneizando a cada 15 minutos). Em seguida, foram adicionados $700 \mu \mathrm{L}$ de clorofórmio: álcool isoamílico (24:1), e então, homogeneizados e centrifugados a $10.000 \mathrm{rpm}$ por 10 minutos. O sobrenadante foi coletado e transferido para novos tubos de $2 \mathrm{~mL}$. Adicionou-se a cada tubo, $450 \mu \mathrm{L}$ de álcool isopropílico (gelado), equivalente a aproximadamente $2 / 3$ do volume coletado, homogeneizando e incubando em seguida a $-20^{\circ} \mathrm{C}$ por 2 minutos. Efetuou-se nova centrifugação a 12.000 rpm por 10 minutos. O DNA isolado foi ressuspenso em $600 \mu \mathrm{L}$ de tampão TE (TrisHCL $10 \mathrm{mM}$, pH 8,0; EDTA $1 \mathrm{mM}$ ) e então, adicionados $200 \mu \mathrm{L}$ de acetato de amônio a 7,5 M. Após misturar suavemente a solução, os tubos foram incubados no gelo por 15 minutos. Uma nova centrifugação a $8.000 \mathrm{rpm}$ por 15 minutos foi realizada e o sobrenadante transferido para tubo de 1,5 mL. Foram adicionados 800 $\mu \mathrm{L}$ de etanol absoluto ao sobrenadante, que então, foi misturado e incubado por 1 hora a $-20^{\circ} \mathrm{C}$. Novamente os tubos foram centrifugados por 10 minutos a $12.000 \mathrm{rpm}$. Toda a parte líquida foi retirada, deixando à mostra, o pellet de DNA aderido ao fundo do tubo. Os tubos então foram lavados, duas vezes, com $500 \mu \mathrm{L}$ de etanol $70 \%$, para eliminar resíduos de sais presentes ao DNA. Finalizando, o pellet foi ressuspenso com $100 \mu \mathrm{L}$ de TE contendo $2 \mu \mathrm{L}$ de ribonuclease (RNAse $10 \mathrm{mg} / \mathrm{mL}$ ), incubado em estufa a $37^{\circ} \mathrm{C}$ por 1 hora, e então, armazenado a $-20^{\circ} \mathrm{C}$. 
O DNA purificado foi submetido à eletroforese em gel de agarose $1 \%$ na presença de brometo de etídio $(1 \mu \mathrm{g} / \mathrm{mL})$ e quantificado visualmente por comparação com o marcador padrão Low DNA Mass Ladder (Invitrogen). As amostras foram corridas a $110 \mathrm{~V}$ por 40 minutos e posteriormente o gel foi visualizado no transiluminador para determinação da quantidade do DNA (Figura 9).

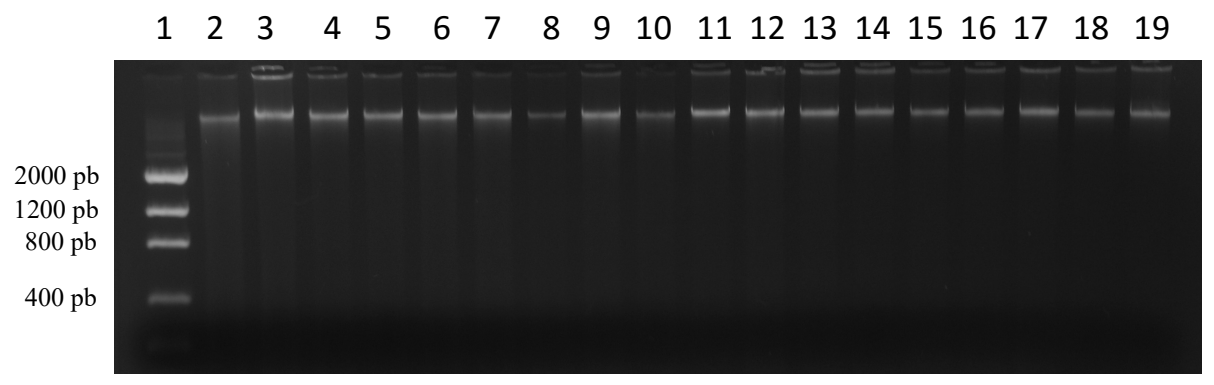

Figura 9. Quantificação de DNA, em gel de agarose, de colônias monospóricas de Mycosphaerella musicola coletados na Fazenda Santos - DF. Coluna 1: marcador Low DNA Mass Ladder (Invitrogen); colunas 2 a 19: 18 isolados da Fazenda Santos.

\subsubsection{Identificação molecular das amostras}

Para confirmação da identidade molecular dos isolados, a região ITS do rDNA ribossômico, parte do gene da actina (ACT) e da histona H3 (HIS) de todos os indivíduos foram analisados. A região ITS do rDNA foi amplificada com os primers universais ITS4 e ITS5 (White et al., 1990) (Tabela 2). Foi preparada uma solução para a PCR, em tubos Eppendorf de $0,2 \mathrm{~mL}$, para um volume final de $25 \mu \mathrm{L}$, contendo 20 ng de DNA, tampão $1 \mathrm{X}, 1,5 \mathrm{mM}$ de $\mathrm{MgCl}_{2}, 0,2 \mathrm{mM}$ de dNTP, 0,4 $\mu \mathrm{M}$ de cada primer e 0,5 U de Taq-DNA polimerase Platinum (Invitrogen). Os tubos para PCR foram colocados em termociclador Esco Swift MaxPro e as reações conduzidas nas seguintes condições: 1 ciclo para etapa inicial de desnaturação $\left(94^{\circ} \mathrm{C}\right.$ por $\left.4 \mathrm{~min}\right)$, seguido de 39 ciclos com uma etapa de desnaturação $\left(92^{\circ} \mathrm{C}\right.$ por $\left.1 \mathrm{~min}\right)$, uma de anelamento $\left(50^{\circ} \mathrm{C}\right.$ por $\left.1 \mathrm{~min}\right)$ e uma de extensão $\left(72^{\circ} \mathrm{C}\right.$ por $\left.1 \mathrm{~min}\right)$ e um último ciclo de extensão final $\left(72^{\circ} \mathrm{C}\right.$ por $\left.5 \mathrm{~min}\right)$. Parte do gene ACT foi amplificada com os 
primers ACT-512F/ACT-783R (Carbone \& Kohn, 1999) e parte do gene HIS com os primers CYLH3F/CYLH3R (Crous et al., 2004) (Tabela 2). As PCR, foram preparadas em tubos Eppendorf de 0,2 $\mathrm{mL}$ para um volume final de $25 \mu \mathrm{L}$, contendo 10 ng de DNA, tampão $1 \mathrm{X}, 1,5 \mathrm{mM}$ de $\mathrm{MgCl}_{2}, 0,2 \mathrm{mM}$ de $\mathrm{dNTP}, 0,2 \mu \mathrm{M}$ de cada primer e 1,5 U de Taq-DNA polimerase. As reação foram conduzidas nas seguintes condições: 1 ciclo para etapa inicial de desnaturação $\left(95^{\circ} \mathrm{C}\right.$ por $\left.5 \mathrm{~min}\right)$, seguido de 35 ciclos com uma etapa de desnaturação $\left(94^{\circ} \mathrm{C}\right.$, por $\left.30 \mathrm{~s}\right)$, uma de anelamento $\left(57^{\circ} \mathrm{C}\right.$ por $30 \mathrm{~s})$ e uma de extensão $\left(72^{\circ} \mathrm{C}\right.$ por $\left.1 \mathrm{~min}\right)$ e um último ciclo de extensão final $\left(72^{\circ} \mathrm{C}\right.$ por $7 \mathrm{~min}$ ). Os produtos das PCRs das regiões ITS do rDNA de 96 indivíduos, representantes de todas as áreas de coleta, assim como dos genes da ACT e da H3 de 24 indivíduos foram purificados e sequenciados pelo método Sanger em ABI3730 (Applied Biosystems) em ambos os sentidos. Cada contig foi montado com o auxílio do programa ChromasPro e analisado via BLASTN, contra o banco de dados de DNA do NCBI, para a confirmação da identidade de $M$. musicola. As sequências da região ITS do isolado 5FC, e dos genes da ACT e da H3 do isolado 10FC da Fazenda Canaã, foram depositadas no Genbank com os números de acesso KP996493, KP996494 e KP996495, respectivamente.

\subsubsection{Determinação dos genes mating types}

Para analisar a distribuição dos idiomorfos mating types em cada população, os genes MAT1-1-1 e MAT1-2-1 foram amplificados em todos os isolados de $M$. musicola utilizando primers desenhados para M. fijiensis descritos por Conde-Ferráez e colaboradores (2010) (Tabela 2). As reações foram preparadas para um volume final de $25 \mu \mathrm{L}$ usando $10 \mathrm{ng}$ de DNA, tampão $1 \mathrm{X}, 3 \mathrm{mM}$ de $\mathrm{MgCl}_{2}, 0,2 \mathrm{mM}$ de $\mathrm{dNTP}, 0,8$ $\mu \mathrm{M}$ de cada primer e 0,35 $\mathrm{U}$ de Taq-DNA polimerase Platinum (Invintrogen). As PCR foram conduzidas em termociclador Esco Swift MaxPro nas seguintes condições: 1 ciclo para etapa inicial de desnaturação $\left(94^{\circ} \mathrm{C}\right.$ por $\left.5 \mathrm{~min}\right)$, seguido de 39 ciclos com uma etapa de desnaturação $\left(95^{\circ} \mathrm{C}\right.$, por $\left.1 \mathrm{~min}\right)$, uma de anelamento $\left(63^{\circ} \mathrm{C}\right.$ por $40 \mathrm{~s})$ e uma de extensão $\left(72^{\circ} \mathrm{C}\right.$ por $\left.40 \mathrm{~s}\right)$ e um último ciclo de extensão final $\left(72^{\circ} \mathrm{C}\right.$ 
por $7 \mathrm{~min}$ ). Alguns amplicons representativos escolhidos aleatoriamente foram purificados com ExoSap (Invitrogen), sequenciados em ambos os sentidos em sequenciador ABI 3730 e analisados via BLASTN para comparação com os domínios conservados alpha e HMG de $M$. musicola no NCBI (http://blast.ncbi.nlm.nih.gov/Blast.cgi). As sequências dos genes MAT1-1-1 e MAT1-1-2 do isolado 1BA de Bom Jesus da Lapa foram depositadas no Genbank com números de acesso KP996496, KP996497, respectivamente.

Tabela 2. Características dos primers para as regiões ITS do rDNA, ACT, H3 e gene mating type e tamanho esperado de fragmento

\begin{tabular}{|c|c|c|}
\hline Primers & Sequências do primers ( $\left.5^{\prime}-3^{\prime}\right)$ & Tamanho esperado (pb) \\
\hline ITS4 & TCCTCCGCTTATTGATATGCTGC & \multirow{2}{*}{600} \\
\hline ITS5 & TCAGCTTGAATGCTAATGTG & \\
\hline ACT-512F & ATG TGC AAG GCC GGT TTC GC & \multirow{2}{*}{300} \\
\hline ACT-783R & TAC GAG TCC TTC TGG CCC AT & \\
\hline CYIH3F & AGG TCC ACT GGT GGC AAG & \multirow{2}{*}{200} \\
\hline CYIH3R & AGC TGG ATG TCC TTG GAC TG & \\
\hline 2723Mt1-F & AGCACCTGGCATGGCTGTGTCACC & \multirow{2}{*}{414} \\
\hline 3137Mt1-R & GCGCAGATGGCGAAGAACTCG & \\
\hline 4327Mt2-F & ATGTCGTCAACCAGCAGAAGAACG & \multirow{2}{*}{700} \\
\hline $5027 \mathrm{Mt} 2-\mathrm{R}$ & CGTCATGCGCTTCTTCTTCTCG & \\
\hline
\end{tabular}

\subsubsection{Identificação de haplótipos}

As análises da estrutura genética de populações de $M$. musicola foram baseadas em 19 locos de SSR específicos para o fungo (Tabela 3) (Molina et al., 2001, Zapater et al., 2008). A seleção dos locos foi baseada nas características polimórficas dos produtos gerados pelos pares de primers: número de alelos por loco, tamanho e especificidade das bandas. Cada PCR foi composta por $15 \mathrm{ng}$ do DNA fúngico; tampão $1 \mathrm{X}(10 \mathrm{mM}$ de Tris- $\mathrm{HCl} ; \mathrm{pH} 8,3 ; 50 \mathrm{mM}$ de $\mathrm{KCl}) ; 0,25 \mathrm{mM}$ de dNTP; $0,2 \mu \mathrm{M}$ de cada primer; $0,25 \mathrm{mg} / \mathrm{mL}$ de BSA e $1 \mathrm{U}$ de Taq-DNA polimerase, com volume final de $13 \mathrm{uL}$. As amplificações foram conduzidas em termociclador Esco Swift MaxPro programado para 5 minutos a $94^{\circ} \mathrm{C}$ para desnaturação inicial, seguido 
de 34 ciclos de 1 minuto a $95^{\circ} \mathrm{C}$, uma etapa de anelamento $\left(50\right.$ a $\left.60^{\circ} \mathrm{C}\right)$ de 1 minuto e 1 minuto e 30 segundos a $72^{\circ} \mathrm{C}$, completado por um ciclo de extensão final de 8 minutos a $72^{\circ} \mathrm{C}$. Os fragmentos amplificados foram visualizados em gel de agarose $1,5 \%$ corado com brometo de etídio. O tamanho dos fragmentos amplificados foram comparados com o DNA ladder $1 \mathrm{~Kb}$ Plus da Invitrogen (Figura 10). Para permitir a genotipagem, os produtos das PCRs foram submetidos à eletroforese em analisador automático de fragmentos ABI 3730 com primers forward marcados com diferentes fluorocromos (HEX e 6- FAM), em conjunto multiplex (cinco a seis locos por corrida) (Figura 10). Para tanto, foi utilizada a mistura de HiDi $(9 \mu \mathrm{L})$, marcador interno $(\mathrm{ROX})(1 \mu \mathrm{L})$ e produto de PCR $(1 \mu \mathrm{L})$, desnaturados por 5 minutos a $95^{\circ} \mathrm{C}$. A detecção dos picos de fluorescência e as análises da genotipagem foram feitas com programa GeneMapper versão 4.1 (Applied Biosystems). 
Tabela 3. Características dos 19 marcadores de microssatélites desenvolvidos para Mycosphaerella musicola utilizados.

\begin{tabular}{|c|c|c|c|c|}
\hline Primers & $\begin{array}{c}\text { Sequência dos primers } \\
\left(5^{\prime}-3^{\prime}\right)\end{array}$ & motif & $\mathbf{A A}(\mathbf{p b})$ & TA $\left({ }^{\circ} \mathrm{C}\right)$ \\
\hline Mm SSR 07 & $\begin{array}{l}\text { F: ACGAGGTTTCAGAAGCAATA } \\
\text { R: TCTTTCACCGAAGAAACCT }\end{array}$ & $(\mathrm{CA}) 50$ & $231-281$ & 55 \\
\hline Mm SSR 10 & $\begin{array}{l}\text { F: GAGAGCATGAAAAGTGGAAA } \\
\text { R: CGTGACACTCGTCAGTTACA }\end{array}$ & $(\mathrm{CA}) 30$ & $145-167$ & 54 \\
\hline Mm SSR 16 & $\begin{array}{l}\text { F: CCATCTGCCTTGAGATAGTC } \\
\text { R: GAATTTATTCCAGCGAAGC }\end{array}$ & $(\mathrm{GA})_{6} \mathrm{AAA}(\mathrm{GA})_{17}$ & $213-233$ & 55 \\
\hline Mm SSR 22 & $\begin{array}{l}\text { F: CCAAAGCTTGAGTTGCTATT } \\
\text { R: ACAACTTTTTGAGGAAAATGTAA }\end{array}$ & $(\mathrm{GAA})_{9}$ & $130-169$ & 55 \\
\hline Mm SSR 23 & $\begin{array}{l}\text { F: CGACCTAGTCGAGGATGATA } \\
\text { R: CGAAGACTTCTGAAAGGTCA }\end{array}$ & $(\mathrm{CTT})_{27}$ & $258-339$ & 55 \\
\hline Mm SSR 24 & $\begin{array}{l}\text { F: TCAAGAGGAGGAGAAGTTGA } \\
\text { R: GGTTCTGATCAAGAGGAGGA }\end{array}$ & $\begin{array}{c}(\mathrm{GAA})_{2} \mathrm{GG}(\mathrm{GAA})_{3} \mathrm{GG} \\
(\mathrm{GAA})_{12}\end{array}$ & $201-206$ & 55 \\
\hline Mm SSR 26 & $\begin{array}{l}\text { F: ATATCTCTTCGTGTTTTGCG } \\
\text { R: AAGTGTGGTCACAGCAAGTT }\end{array}$ & $(\mathrm{CAA})_{8}$ & $166-169$ & 55 \\
\hline Mm SSR 31 & $\begin{array}{l}\text { F: AACCACATCTTCGATCAGG } \\
\text { R: CACATGGAATATCCTTGGTC }\end{array}$ & $(\mathrm{AC})_{27}$ & $188-216$ & 55 \\
\hline Mm SSR 34 & $\begin{array}{l}\text { F: CTCGCTGCCTGATTATTCT } \\
\text { R: AGATGGCATCGCTTCAC }\end{array}$ & $(\mathrm{CA}) 19$ & $237-281$ & 54 \\
\hline Mm SSR35 & $\begin{array}{l}\text { F: TAACAATGTCCCTGAGAAGC } \\
\text { R: GCCTTATCTGGAAAGTATCGT }\end{array}$ & $(\mathrm{CA})_{4} \mathrm{AA}(\mathrm{CA})_{26}$ & $233-273$ & 55 \\
\hline Mm SSR 39 & $\begin{array}{l}\text { F: TGCGAATTCCATTGATATG } \\
\text { R: CGTGTGCTGACGAGAGAT }\end{array}$ & $(\mathrm{CA})_{19}$ & $159-203$ & 55 \\
\hline Mm SSR 44 & $\begin{array}{l}\text { F: CCTCACTCTCGCTCATACA } \\
\text { R: AGAATGGACGAAAAACACTG }\end{array}$ & $(\mathrm{CA})_{9}(\mathrm{CT})_{14}$ & $122-140$ & 55 \\
\hline Mm SSR 46 & $\begin{array}{l}\text { F: CGTGGACCTATTGTCAACTC } \\
\text { R: TGGGTTACATTTACGAGAGAA }\end{array}$ & $(\mathrm{CT})_{6}(\mathrm{GT})_{38}$ & 261 & 55 \\
\hline Mm SSR 103 & $\begin{array}{l}\text { F: CAAGCAAGCAAGCAAGCAC } \\
\text { R: TGGAAATGGGTCGGAAACG }\end{array}$ & $\begin{array}{c}(\mathrm{CAAG})_{4} \mathrm{CAC}(\mathrm{CA})_{8} \\
\mathrm{CGCC}(\mathrm{GCAC})_{5}\end{array}$ & $78-116$ & 60 \\
\hline Mm SSR 104 & $\begin{array}{l}\text { F: TGAGAAGATGAATGTGAAGT } \\
\text { R: CTTGCGTAGGCGTGATA }\end{array}$ & $(\mathrm{GT})_{25}$ & $101-119$ & 55 \\
\hline Mm SSR 106 & $\begin{array}{l}\text { F: AGCCTTGTAGATGTTTGTGT } \\
\text { R: ATGGAAGTTGCGAGAATGTT }\end{array}$ & $(\mathrm{GT})_{3} \mathrm{~T}(\mathrm{GT})_{3} \mathrm{GC}(\mathrm{GT})_{7}$ & $139-157$ & 54 \\
\hline Mm SSR 109 & $\begin{array}{l}\text { F: TCGAACAGCGACTTTATTC } \\
\text { R: CAAAAGCGGAAAATGGTCA }\end{array}$ & $(\mathrm{CAG})_{4}(\ldots)(\mathrm{TG})_{19}$ & $179-191$ & 55 \\
\hline Mm SSR 110 & $\begin{array}{l}\text { F: TCCGCATTTTCCCCAGTCCT } \\
\text { R: GCTATTCTTTCCACGCACAC }\end{array}$ & $(\mathrm{AG})_{11}(\mathrm{TG}) 9$ & $193-197$ & 60 \\
\hline Mm SSR 111 & $\begin{array}{l}\text { F: TTTCCTTGTCACCTGTTTGC } \\
\text { R: TTCCTGGGAATGCTCTACGG }\end{array}$ & $(\mathrm{GT}){ }_{13} \mathrm{CTCC}(\mathrm{CT})_{4}$ & $192-228$ & 60 \\
\hline
\end{tabular}

$\mathrm{AA}=$ amplitude alélica; $\mathrm{TA}=$ temperatura de anelamento. 

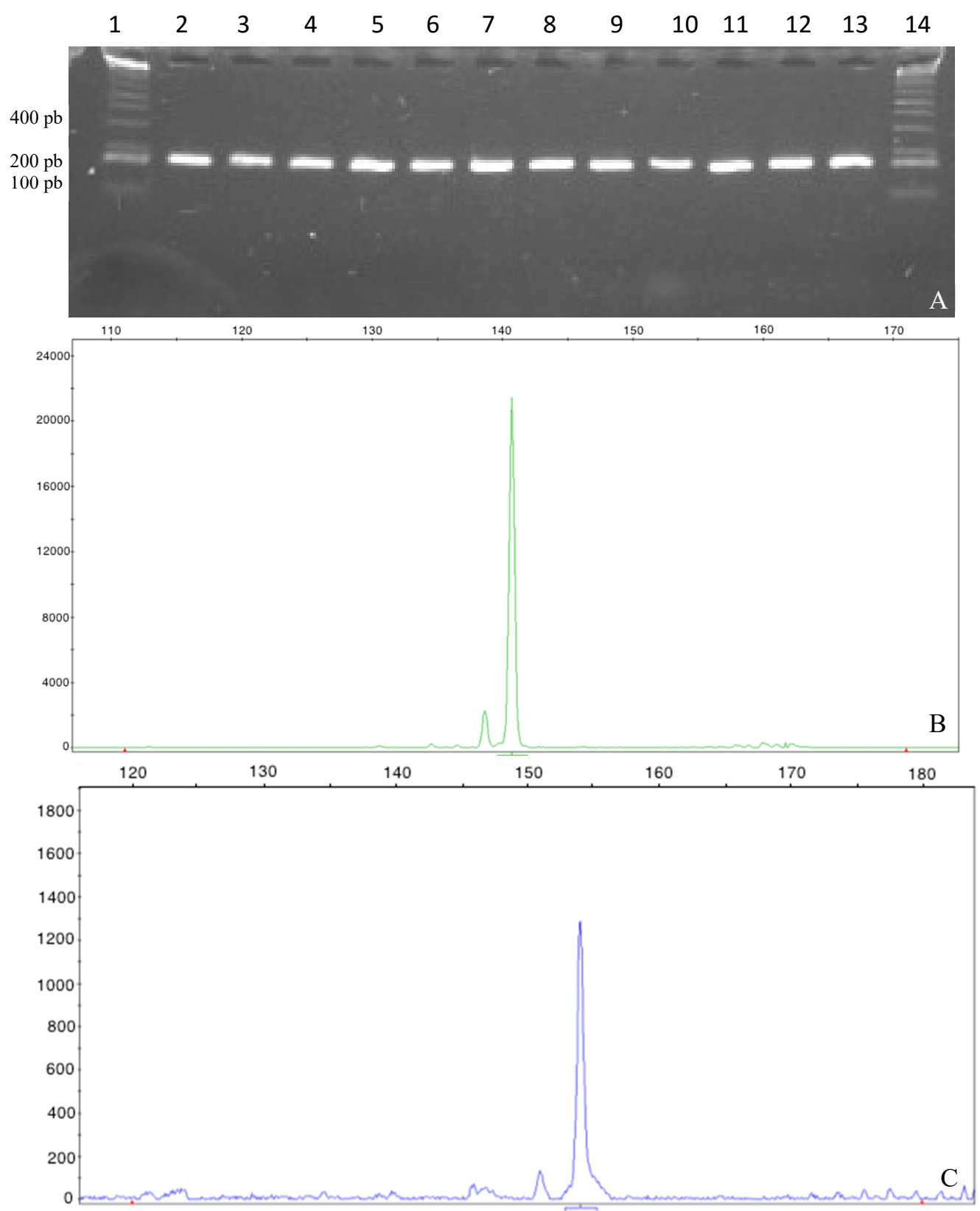

Figura 10. Amplificação e genotipagem dos locos SSR. A. confirmação em gel de agarose da amplificação do loco SSRMm26 em isolados representativos (Colunas 2 a 13). Colunas 1 e 14: DNA ladder 1Kb Plus da Invitrogen; B. Genotipagem para os locos SSR106 (pico verde); C. SSR22 (pico azul) sob análise através do programa GeneMapper. Eixo x: tamanho do fragmento; eixo y: intensidade da fluorescência. 


\subsubsection{Análise dos dados}

Para o arredondamento dos tamanhos alélicos foi utilizado o programa AlleloBin (Prasanth et al., 2006). Haplótipos e suas frequências em cada população foram identificados através do programa SNAP Workbench (Price \& Carbone, 2005), a partir da construção de uma matriz binária dos dados multilocus.

A frequência alélica em cada população e o equilíbrio de Hardy-Weinberg (EHW) foram calculados usando o programa GDA, versão 1.1 (Lewis \& Zaykin, 2001). O desequilíbrio de ligação de multilocus foi analisado usando o índice de associação $\left(I_{A}\right.$ ou $\left.r B a r D\right)$ estimado para cada população. O $r B a r D$ é uma medida alternativa do índice de associação e é menos sensível ao número de locos quando comparado com $I_{A}$. O valor de $\operatorname{rBarD}$ foi estimado e a hipótese nula de $r B a r D=0$ (equilíbrio gamético) foi testada com 1.000 permutações utilizando o programa MULTILOCUS, versão 1.3 (Agapow \& Burt, 2001).

A variação genética dentro e entre populações foi calculada com base na análise de variância molecular (AMOVA). Componente de variância e valor da diversidade genética $\left(F_{S T}\right)$ foi testado por 1.023 permutações de haplótipos entre populações para determinar níveis de significância $(\mathrm{P} \leq 0.05)$, com auxílio do programa Arlequin 3.5.1.2 (Excoffier \& Lischer, 2010).

A estrutura genética das populações foi analisada calculando a diversidade gênica total $\left(H_{T}\right)$ e a média da diversidade gênica dentro de cada população $\left(H_{S}\right)$, baseado em Nei (1978), usando o programa POPGENE 1.32 (Yeh \& Boyle, 1997). O fluxo gênico em cada estado e a distância genética de Nei (1978) também foram calculados com o programa POPGENE. A relação entre a distância genética e geográfica dos isolados de M. musicola foi analisada por meio do teste de Mantel, com 1.000 permutações.

Análises de agrupamento foram realizadas para inferir a estrutura genética de populações utilizando o programa STRUCTURE, versão 2.3.4 (Pritchard et al., 2000). O conjunto de dados foi analisado utilizando o modelo de mistura, 20 vezes com 
750.000 cadeias MCMC após "burn-in” de 250.000. O número de grupos de base $(\mathrm{k})$ variou de 1 a 16 (número de populações $(13)+3$ ).

Para mensurar a diversidade genotípica (riqueza e equitabilidade), o índice de Shannon-Wiener (S') foi calculado. Com base no número de indivíduos, os valores de riqueza de populações [E(gn)] foram estimados para as populações dos estados separados e suas sublocalidades. Por se tratar de populações com diferentes números de indivíduos, elas foram escalonadas por curvas de rarefação $[\mathrm{E}(\mathrm{g})]$. O índice de diversidade, riqueza e o teste de Mantel foram estimados pelo programa $\mathrm{R}$, pacote 'vegan' (Oksanen et al., 2013).

As frequências dos idiomorfos mating types de cada população de $M$. musicola foram analisadas para determinar a ocorrência de algum desvio significativo da proporção esperada (1:1), utilizando o teste $x^{2}$ (Conde-Ferráez et al., 2010).

\subsection{Resultados}

\subsubsection{Identificação molecular}

Um fragmento único da região ITS do rDNA, gerado na PCR com tamanho esperado de 600 pb para fungos Cercospora (Crous et al., 2011) foi amplificado para os 187 isolados de M. musicola (Figura 11). Similarmente, amplificação específica de parte dos genes ACT e HIS resultaram em produtos de tamanho esperado de 300 e $200 \mathrm{pb}$, respectivamente (Figura 12). Análises das sequências via BLASTN, depositadas no Genbank, para as três regiões genômicas confirmaram a identidade de todos os isolados como M. musicola.

\subsubsection{Sequenciamento e frequência dos genes mating types}

Todos os produtos de PCR dos genes mating types sequenciados, mostraram $100 \%$ de identidade para os idiomorfos mating types de M. musicola, baseado nas análises via BLASTN contra as sequências no Genbank, confirmando a identidade 
dos fragmentos amplificados.

Dos 187 isolados caracterizados, 97 apresentaram um único fragmento no tamanho esperado de $400 \mathrm{pb}$ para o gene MAT1-1-1. Para os demais 90 isolados, um fragmento de 700 pb para o gene MAT1-2-1 foi observado (Figura 13). Com exceção dos isolados coletados no Rio Grande do Norte com 100\% dos indivíduos representados por idiomorfos MAT1-2 e dos isolados da Fazenda Santos - DF, as populações em estudo não apresentaram diferença significativa na proporção de 1:1 de idiomorfos MAT1-1 e MAT1-2, o que permite predizer a ocorrência de reprodução sexuada nessas populações (Tabela 4).

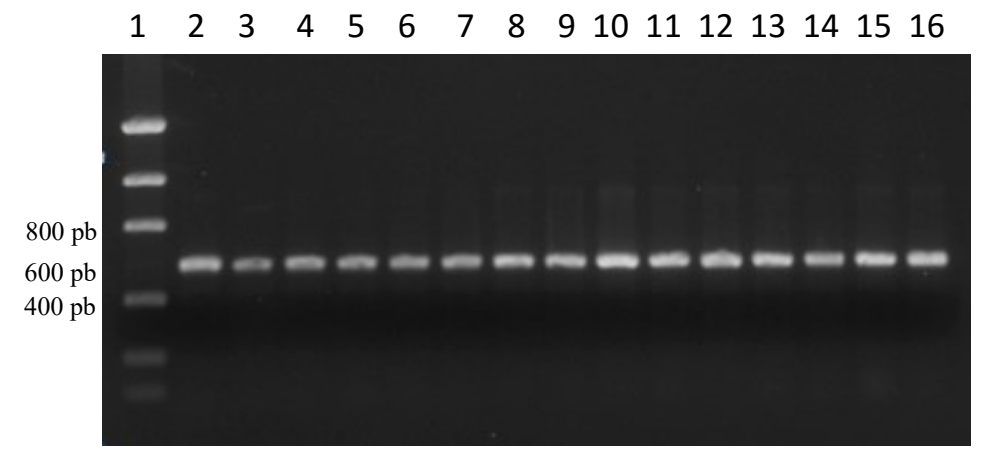

Figura 11. Produto da amplificação da região ITS do rDNA, em gel de agarose, de colônias monospóricas de Mycosphaerella musicola coletadas na Estação Biológica - UnB (Colunas 2 a 16). Coluna 1: DNA ladder $1 \mathrm{~Kb}$ da Invitrogen. 


\section{$\begin{array}{llllllllllllll}1 & 2 & 3 & 4 & 5 & 6 & 7 & 8 & 9 & 10 & 11 & 12 & 13 & 14\end{array}$}

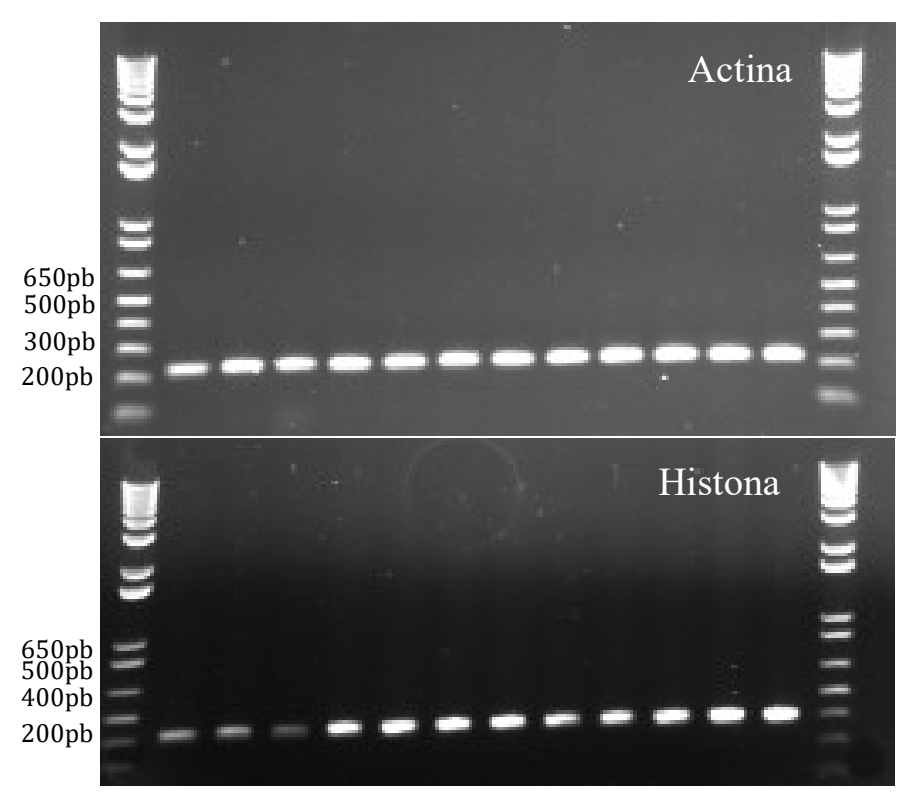

Figura 12. Produto da amplificação de parte dos genes actina (a) e histona H3 (b), em gel de agarose, de representantes de Mycosphaerella musicola das diferentes localidades (Colunas 2 a 13). Colunas 1 e 14: DNA ladder $1 \mathrm{~Kb}$ Plus da Invitrogen.

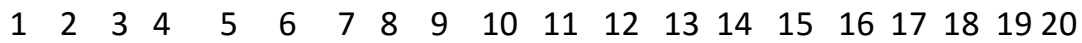



Figura 13. Amplificação da região mating type, em gel de agarose, do DNA de colônias monospóricas de Mycosphaerella musicola coletadas na Estação Biológica - UnB (Colunas 2 a 20). Coluna 1: DNA ladder $1 \mathrm{~Kb}$ da Invitrogen. 
Tabela 4. Distribuição de genes mating types e desequilíbrio de ligação em populações de Mycosphaerella musicola.

\begin{tabular}{|c|c|c|c|c|c|}
\hline Localidade & $\begin{array}{c}M A T 1-1 \\
(\%)\end{array}$ & $\begin{array}{c}M A T 1-2 \\
(\%)\end{array}$ & $\mathbf{x}^{2}$ & rBarD & $\mathbf{P}$ \\
\hline \multicolumn{6}{|l|}{ Distrito Federal } \\
\hline 1. Estação Biológica & 36 & 64 & 1,4400 & $-0,001$ & 0,540 \\
\hline 2. Embrapa Cerrados & 59 & 41 & 0,4091 & 0,012 & 0,100 \\
\hline 3. Fazenda Canaã & 60 & 40 & 0,8333 & 0,009 & $0,055^{*}$ \\
\hline 4. São João da Aliança & 23 & 77 & 2,7692 & $-0,015$ & 0,862 \\
\hline 5. Fazenda Santos & 82,6 & 17,4 & $8,5217 * *$ & 0,002 & 0,357 \\
\hline \multicolumn{6}{|l|}{ Bahia } \\
\hline 6. Bom Jesus da Lapa & 62 & 38 & 0,7619 & 0,075 & $0,001 * *$ \\
\hline 7. Tancredo Neves & 41 & 59 & 0,0833 & 0,12 & $0,001 * *$ \\
\hline 8. Sebastião Laranjeiras & 33 & 67 & 0,1667 & 0,48 & $0,001 * *$ \\
\hline 9. Itajuípe & 40 & 60 & 0 & 0,27 & $0,001 * *$ \\
\hline 10. Barra do Choça & 80 & 20 & 0,8000 & 0,005 & 0,411 \\
\hline \multicolumn{6}{|l|}{ Minas Gerais } \\
\hline 11. Lavras & 33 & 67 & 0,4444 & 0,11 & $0,001 * *$ \\
\hline \multicolumn{6}{|l|}{ Rio Grande do Norte } \\
\hline 12. Ipanguaçu & 0 & 100 & 1,3333 & 1,00 & $0,005 * *$ \\
\hline 13. Baraúna (BRN) & 0 & 100 & 3,2000 & $-0,045$ & 0,780 \\
\hline Total & 97 & 90 & - & - & - \\
\hline
\end{tabular}

A hipótese nula do equilíbrio de ligação multilocus foi rejeitada se $\mathrm{P} \leq 0,01$ ou 0,05 . ** altamente significante; * significante 


\subsubsection{Diversidade genética dentro das populações}

Para o total de 187 isolados, distribuídos em 13 populações, a genotipagem resultou em 189 alelos distribuídos em 19 locos polimórficos. De acordo com a frequência alélica, o número de alelos na população total variou de 3 a 35 alelos com as populações de Ipanguaçu e Fazenda Santos apresentando os menores e maiores números de alelos, respectivamente (Tabela 5).

Entre os 187 isolados analisados, 48 haplótipos (25\%) diferentes foram detectados, sendo que 16 deles (33\%), ocorreram uma única vez em toda a amostragem (Tabela 6). As populações de M. musicola de Barra do Choça-BA e Baraúna-RN foram dominadas por haplótipos únicos. A população oriunda da Fazenda Canãa apresentou o maior número de haplótipos (24) dos quais 18 só apareceram uma vez entre os indivíduos da população, valor correspondente a $50 \%$ da população de M. musicola coletada no local (Tabela 6). Os haplótipos H1, H8 e H24 foram os mais abundantes com um total de 10, 14 e 11 indivíduos, distribuídos por no mínimo 4 populações. O haplótipo H8 foi o mais compartilhado, estando presente em 9 das 13 populações de M. musicola estudadas (Tabela 6). De acordo com a AMOVA, a maior diversidade genética ocorreu entre os indivíduos dentro das populações $(92,5 \%)(\mathrm{P}=0,00)$ (Tabela 7). Embora a diversidade entre os estados $(2,7 \%)$ e entre as populações dentro dos estados $(4,75 \%)$ tenha sido baixa, ela foi altamente significativa $(\mathrm{P} \leq 0,01)$.

A média da diversidade gênica na amostra total $\left(H_{T}\right)$ foi de 0,49 . Para cada população, a média da diversidade gênica $\left(H_{S}\right)$ variou de 0,17 a 0,49 (Tabela 5). A população de $M$. musicola de Ipanguaçu -RN apresentou a menor diversidade gênica e CPAC-DF juntamente com a Fazenda Canaã-DF apresentaram os maiores valores.

As diversidades genéticas das populações do patógeno, com base no índice de Shannon-Wiener (S') estão apresentadas na Tabela 5. Análise da riqueza $(E g)$ de indivíduos das populações amostradas indicou ausência de diferença entre as 13 populações, uma vez que o intervalo de confiança mostrou sobreposição nos valores de $E g$. Contudo, considerando cada estado como uma população, houve diferença na 
riqueza entre Minas Gerais e os demais estados, e Rio Grande do Norte se diferenciou tanto de Minas Gerais quanto do Distrito Federal. 
Tabela 5. Distribuição dos alelos, diversidade gênica e sumário estatístico das 13 populações de Mycosphaerella musicola.

\begin{tabular}{lccccccc}
\hline \multicolumn{1}{c}{ Localidade } & $\begin{array}{c}\text { Total de } \\
\text { isolados }\end{array}$ & $\mathbf{N}$ & $\mathbf{A}$ & $\mathbf{H}_{\mathbf{S}}$ & $\mathbf{S}$ & $\mathbf{E}(\mathbf{g n})$ & $\mathbf{E}(\mathbf{g})$ \\
\hline Distrito Federal & $\mathbf{( 1 1 9 )}$ & - & - & $\mathbf{( 0 , 5 2 )}$ & $\mathbf{( 3 , 5 0 )}$ & $\mathbf{( 8 3 )}$ & $\mathbf{7 , 2 3}( \pm \mathbf{0 , 7 7 )}$ \\
1. Estação Biológica & 25 & 21,6 & 4,42 & 0,48 & 2,73 & 17 & $2,90( \pm 0,30)$ \\
2. Embrapa Cerrados & 22 & 12,7 & 3,94 & 0,49 & 2,56 & 14 & $2,88( \pm 0,32)$ \\
3. Fazenda Canaã & 36 & 24,4 & 4,78 & 0,49 & 3,01 & 24 & $2,90( \pm 0,29)$ \\
4. São João da Aliança & 13 & 22,2 & 4,31 & 0,46 & 3,35 & 11 & $2,92( \pm 0,26)$ \\
5. Fazenda Santos & 23 & 35,3 & 5,68 & 0,47 & 2,72 & 17 & $2,90( \pm 0,29)$ \\
Bahia & $\mathbf{5 1})$ & - & - & $\mathbf{( 0 , 4 2 )}$ & $\mathbf{( 2 , 7 4 )}$ & $\mathbf{( 3 0 )}$ & $\mathbf{6 , 5 4}( \pm \mathbf{0 , 9 4})$ \\
6. Bom Jesus da Lapa & 21 & 20,1 & 3,26 & 0,37 & 2,25 & 11 & $2,77( \pm 0,43)$ \\
7. Tancredo Neves & 14 & 13,7 & 2,94 & 0,36 & 1,77 & 7 & $2,62( \pm 0,51)$ \\
8. Sebastião Laranjeiras & 6 & 5,8 & 1,94 & 0,28 & 0,86 & 3 & $2,00( \pm 0,63)$ \\
9. Itajuípe & 5 & 4,6 & 2,31 & 0,29 & 1,33 & 4 & $2,70( \pm 0,45)$ \\
10. Barra do Choça & 5 & 4,9 & 2,10 & 0,37 & 1,60 & 5 & $3(\mathrm{NaN})$ \\
Minas Gerais & $\mathbf{( 9 )}$ & - & - & $\mathbf{( 0 , 4 1 )}$ & $\mathbf{( 1 , 5 2 )}$ & $\mathbf{( 5 )}$ & $\mathbf{4 , 7 7}( \pm \mathbf{0 , 4 1})$ \\
11. Lavras & 9 & 8,6 & 2,52 & 0,41 & 1,52 & 5 & $2,59( \pm 0,50)$ \\
Rio Grande do Norte & $\mathbf{( 8 )}$ & - & - & $\mathbf{( 0 , 3 5 )}$ & $\mathbf{( 1 , 6 6 )}$ & $\mathbf{( 7 )}$ & $\mathbf{6 ( 0 )}$ \\
12. Ipanguaçu & 3 & 3 & 1,42 & 0,17 & 0,63 & 2 & $2(0)$ \\
13. Baraúna & 5 & 4,8 & 2,36 & 0,35 & 1,60 & 5 & $3(\mathrm{NaN})$ \\
\hline H & - & - & - & $\mathbf{0 , 4 9}$ & - & - & - \\
\hline Média & - & $\mathbf{1 4}$ & $\mathbf{3 , 2 3}$ & - & - & - & - \\
\hline Total & $\mathbf{1 8 7}$ & & - & - & $\mathbf{3 . 5 5}$ & $\mathbf{1 2 5}$ & - \\
\hline
\end{tabular}

$\mathrm{N}=$ Número total de alelos; $\mathrm{A}=$ média de alelos/loco; $\mathrm{H}_{\mathrm{T}}=$ diversidade gênica na amostra total; $\mathrm{H}_{\mathrm{S}}=$ média da diversidade gênica em cada população; $\mathrm{S}$ = índice de Shannon; $\mathrm{E}(\mathrm{gn})=$ riqueza; $\mathrm{E}(\mathrm{g})=$ riqueza baseada no menor tamanho amostral das 13 populações (3) e dos quatro estados (8); (-) não aplicável 
Tabela 6. Identificação, distribuição e frequência de haplótipos nas populações de Mycosphaerella musicola.

\begin{tabular}{|c|c|c|c|c|c|c|c|c|c|c|c|c|c|c|}
\hline Haplótipos & $\begin{array}{c}\text { Estacão } \\
\text { Biológica- } \\
\text { DF }\end{array}$ & $\begin{array}{c}\text { CPAC- } \\
\text { DF }\end{array}$ & $\begin{array}{c}\text { Fazenda } \\
\text { Canãa -DF }\end{array}$ & $\begin{array}{c}\begin{array}{c}\text { São João } \\
\text { da Aliança } \\
\text { - GO }\end{array} \\
\end{array}$ & $\begin{array}{c}\text { Fazenda } \\
\text { Santos- } \\
\text { DF } \\
\end{array}$ & $\begin{array}{c}\text { Bom Jesus } \\
\text { da Lapa- } \\
\text { BA }\end{array}$ & $\begin{array}{c}\text { Tancredo } \\
\text { Neves-BA }\end{array}$ & $\begin{array}{c}\begin{array}{c}\text { Sebastião } \\
\text { Laranjeiras } \\
\text {-BA }\end{array} \\
\end{array}$ & Itajuípe-BA & $\begin{array}{c}\begin{array}{c}\text { Barra do } \\
\text { Choca- } \\
\text { BA }\end{array} \\
\end{array}$ & $\begin{array}{c}\text { Lavras- } \\
\text { MG }\end{array}$ & $\begin{array}{c}\text { Ipanguacu- } \\
\mathrm{RN}\end{array}$ & $\begin{array}{c}\text { Barán } \\
\text { a-RN }\end{array}$ & $\begin{array}{c}\text { Total } \\
\text { individuos/ } \\
\text { haplótipo }\end{array}$ \\
\hline $\mathrm{HI}$ & 3 & - & 3 & 1 & 1 & 2 & - & & - & & - & - &  & \\
\hline H2 & 1 & - & - & 1 & - & - & 1 & - & - & - & - & - & - & 3 \\
\hline $\mathrm{H} 3$ & 1 & 1 & 2 & - & 1 & - & - & - & - & - & - & - & - & 5 \\
\hline $\mathrm{H} 4$ & 1 & - & - & - & - & - & - & - & - & - & - & - & - & 1 \\
\hline H5 & 1 & - & - & 1 & - & - & - & - & - & - & - & - & - & 2 \\
\hline H6 & 3 & - & 2 & - & 3 & - & - & - & - & - & - & - & - & 8 \\
\hline $\mathrm{H} 7$ & 1 & - & 1 & - & - & - & - & - & & - & - & - & - & 2 \\
\hline H8 & 2 & 2 & 1 & 1 & 1 & - & 3 & - & 2 & 1 & - & 1 & - & 14 \\
\hline H9 & 2 & 2 & 4 & - & - & - & - & - & - & - & - & - & - & 8 \\
\hline H10 & 1 & - & 1 & - & 1 & - & - & 4 & - & - & - & - & 1 & 8 \\
\hline H11 & 1 & - & - & - & - & - & - & - & - & - & 2 & - & - & 3 \\
\hline H12 & 1 & 1 & 1 & 1 & - & - & - & - & - & - & - & - & 1 & 5 \\
\hline H13 & 2 & - & - & - & - & - & - & - & - & - & - & - & - & 2 \\
\hline H14 & 1 & - & - & - & - & - & 1 & - & 1 & - & - & - & - & 3 \\
\hline H15 & 1 & - & - & - & - & - & - & - & - & - & - & - & - & 1 \\
\hline H16 & 2 & - & 1 & - & 1 & 2 & 1 & 1 & - & - & - & - & - & 8 \\
\hline H17 & 1 & - & 1 & - & - & - & - & - & - & - & - & - & - & 2 \\
\hline H18 & - & 2 & - & - & 1 & 1 & 1 & - & - & 1 & 2 & - & - & 8 \\
\hline H19 & - & 2 & 3 & - & 1 & 1 & - & - & - & - & - & - & - & 7 \\
\hline H 20 & - & 1 & 1 & - & - & 4 & - & - & 1 & - & - & - & - & 7 \\
\hline H21 & - & 3 & 4 & - & - & - & - & - & 1 & - & - & - & - & 8 \\
\hline H22 & - & 1 & - & - & - & - & - & - & - & - & - & - & - & 1 \\
\hline H23 & - & 2 & 1 & - & 2 & 1 & - & - & - & - & - & - & 1 & 7 \\
\hline H24 & - & 2 & - & - & - & 4 & 4 & - & - & - & 1 & - & - & 11 \\
\hline H25 & - & 1 & - & - & - & - & - & - & - & - & - & - & - & 1 \\
\hline H26 & - & 1 & - & - & - & - & - & - & - & - & - & - & - & 1 \\
\hline H27 & - & 1 & - & - & - & 2 & - & - & - & - & - & - & - & 3 \\
\hline $\mathrm{H} 28$ & - & - & 1 & - & 1 & - & - & - & - & - & - & - & - & 2 \\
\hline $\mathrm{H} 29$ & - & - & 1 & - & - & - & - & - & - & - & - & - & - & 1 \\
\hline $\mathrm{H} 30$ & - & - & 1 & - & - & - & - & - & - & - & - & - & - & 1 \\
\hline $\mathrm{H} 31$ & - & - & 1 & - & - & - & - & - & - & - & - & 2 & 1 & 4 \\
\hline $\mathrm{H} 32$ & - & - & 1 & - & - & - & - & - & - & - & - & - & - & 1 \\
\hline $\mathrm{H} 33$ & - & - & 1 & - & - & - & - & - & - & 1 & - & - & - & 2 \\
\hline $\mathrm{H} 34$ & - & - & 1 & - & 1 & 2 & - & - & - & 1 & 1 & - & - & 6 \\
\hline H35 & - & - & 1 & 1 & 1 & - & - & - & - & - & - & - & - & 3 \\
\hline $\mathrm{H} 36$ & - & - & 1 & - & - & - & - & - & - & - & - & - & - & 1 \\
\hline $\mathrm{H} 37$ & - & - & 1 & - & - & - & - & - & - & - & - & - & - & 1 \\
\hline $\mathrm{H} 38$ & - & - & - & 1 & - & - & - & - & - & - & - & - & - & 1 \\
\hline H39 & - & - & - & 2 & 2 & - & - & - & - & - & - & - & - & 4 \\
\hline $\mathrm{H} 40$ & - & - & - & 2 & 3 & - & - & 1 & - & - & - & - & 1 & 7 \\
\hline $\mathrm{H} 41$ & - & - & - & 1 & - & - & - & - & - & - & - & - & - & 1 \\
\hline $\mathrm{H} 42$ & - & - & - & 1 & - & - & - & - & - & - & - & - & - & 1 \\
\hline $\mathrm{H} 43$ & - & - & - & - & 1 & - & - & - & - & - & 3 & - & - & 4 \\
\hline $\mathrm{H} 44$ & - & - & - & - & 1 & - & - & - & - & - & - & - & - & 1 \\
\hline $\mathrm{H} 45$ & - & - & - & - & 1 & - & - & - & - & 1 & - & - & - & 2 \\
\hline $\mathrm{H} 46$ & - & - & - & - & - & 1 & - & - & - & - & - & - & - & 1 \\
\hline $\mathrm{H} 47$ & - & - & - & - & - & 1 & - & - & - & - & - & - & - & 1 \\
\hline $\mathrm{H} 48$ & - & - & - & - & - & - & 3 & - & - & - & - & - & - & 3 \\
\hline $\begin{array}{l}\text { Total indivíduo/ } \\
\text { pop }\end{array}$ & 25 & 22 & 36 & 13 & 23 & 21 & 14 & 6 & 5 & 5 & 9 & 3 & 5 & 187 \\
\hline $\begin{array}{l}\text { Total } \\
\text { genótipo/pop }\end{array}$ & 17 & 14 & 24 & 11 & 17 & 11 & 7 & 3 & 4 & 5 & 5 & 3 & 5 & - \\
\hline $\begin{array}{l}\text { Total haplótipos } \\
\text { unicos/pop }\end{array}$ & 11 & 7 & 18 & 9 & 13 & 5 & 4 & 2 & 3 & 5 & 2 & 1 & 5 & - \\
\hline
\end{tabular}


Tabela 7. Variabilidade genética de Mycosphaerella musicola de acordo com AMOVA.

\begin{tabular}{lccccc}
\hline \multicolumn{1}{c}{ Fonte de variação } & GL & $\begin{array}{c}\text { Componente de } \\
\text { variância }\end{array}$ & Variação (\%) & F & P \\
\hline $\begin{array}{l}\text { Entre estados } \\
\begin{array}{l}\text { Entre populações } \\
\text { dentro dos estados }\end{array}\end{array}$ & 3 & 0,27185 & 2,7 & 0,02699 & 0,01 \\
$\begin{array}{l}\text { Dentro das } \\
\text { populações }\end{array}$ & 174 & 0,47804 & 4,75 & 0,04877 & 0,00 \\
\hline \multicolumn{1}{c}{ Total } & 186 & 10,07400 & 92,56 & 0,00744 & 0,00 \\
\hline
\end{tabular}

$\mathrm{GL}=$ Grau de liberdade; $\mathrm{F}=$ =índice de fixação, onde: $\mathrm{F}=0$ = equilíbrio de $\mathrm{HW} ; \mathrm{F}>0$ = alelos fixados na população; $\mathrm{F}<0$ = ausência de fixação, diversidade maior que a esperada para população em EHW. Quanto menor o $\mathrm{F}$, menor a taxa de endogamia; $\mathrm{P}=$ Significância $(1 \%)$

\subsubsection{Diversidade genética entre populações}

Análises da diversidade genética $\left(F_{S T}\right)$, entre pares de populações de $M$. musicola (Tabela 8) revelaram uma variação de $-0,04$ a 0,28 . Os valores de $F_{S T}$ entre as populações mais próximas do Distrito Federal: Estação Biológica e CPAC (22km de distância) e entre as mais distantes: Baraúna-RN e Lavras-MG (1900km de distância) foram de 0,05 e 0,07, respectivamente, indicando baixa variabilidade entre as mesmas. Em contraste, a maior diversidade genética foi observada entre as populações do patógeno oriundas de Ipanguaçu - RN e Sebastião Laranjeiras - BA (1.220 km de distância), com $F_{S T}$ de 0,28. As populações provenientes do Distrito Federal apresentaram baixa diversidade entre si. Já a de Sebastião Laranjeiras-BA foi a mais significativamente diferente das demais: Estação Biológica, CPAC, Fazenda Canaã, São João da Aliança e Fazenda Santos, Bom Jesus da Lapa, Lavras e Ipanguaçu. Outras diferenças foram observadas entre São João da Aliança e Bom Jesus da Lapa assim como entre Baraúna e Tancredo Neves. 
Tabela 8. Diversidade genética $\left(\mathrm{F}_{\mathrm{ST}}\right)$ em pares de populações de Mycosphaerella musicola.

\begin{tabular}{|c|c|c|c|c|c|c|c|c|c|c|c|c|c|}
\hline \multirow[b]{2}{*}{ ID pop } & \multicolumn{5}{|c|}{ Distrito Federal } & \multicolumn{5}{|c|}{ Bahia } & \multirow{2}{*}{$\begin{array}{c}\begin{array}{c}\text { Minas } \\
\text { Gerais }\end{array} \\
\text { LV }\end{array}$} & \multicolumn{2}{|c|}{$\begin{array}{c}\text { Rio Grande do } \\
\text { Norte }\end{array}$} \\
\hline & EsBio & CPAC & FzCa & SJA & STOS & BJL & TaNe & SeLa & ITJ & BaCh & & IPG & BRN \\
\hline EsBio & $* * *$ & $* * *$ & $* * *$ & $* * *$ & $* * *$ & $* * *$ & $* * *$ & $* * *$ & $* * *$ & $* * *$ & $* * *$ & $* * *$ & $* * *$ \\
\hline CPAC & $0,05+$ & $* * *$ & $* * *$ & $* * *$ & $* * *$ & $* * *$ & $* * *$ & $* * *$ & $* * *$ & $* * *$ & $* * *$ & $* * *$ & $* * *$ \\
\hline $\mathbf{F z C a}$ & 0,01 & 0,003 & $* * *$ & $* * *$ & $* * *$ & $* * *$ & $* * *$ & $* * *$ & $* * *$ & $* * *$ & $* * *$ & $* * *$ & $* * *$ \\
\hline SJA & 0,03 & $0,08+$ & $0,06+$ & $* * *$ & $* * *$ & $* * *$ & $* * *$ & $* * *$ & $* * *$ & $* * *$ & $* * *$ & $* * *$ & $* * *$ \\
\hline STOS & $0,02+$ & $0,04+$ & 0,01 & $-0,006$ & $* * *$ & $* * *$ & $* * *$ & $* * *$ & $* * *$ & $* * *$ & $* * *$ & $* * *$ & $* * *$ \\
\hline BJL & $0,08+$ & 0,02 & $0,06+$ & $0,12+$ & $0,08+$ & $* * *$ & $* * *$ & $* * *$ & $* * *$ & $* * *$ & $* * *$ & $* * *$ & $* * *$ \\
\hline TaNe & $0,09+$ & $0,05+$ & $0,10+$ & $0,08+$ & $0,09+$ & $0,05+$ & $* * *$ & $* * *$ & $* * *$ & $* * *$ & $* * *$ & $* * *$ & $* * *$ \\
\hline SeLa & $0,14+$ & $0,22+$ & $0,17+$ & $0,20+$ & $0,13+$ & $0,21+$ & $0,27+$ & $* * *$ & $* * *$ & $* * *$ & $* * *$ & $* * *$ & $* * *$ \\
\hline ITJ & 0,03 & $-0,03$ & 0,01 & 0,05 & 0,02 & 0,02 & 0,00 & 0,27 & $* * *$ & $* * *$ & $* * *$ & $* * *$ & $* * *$ \\
\hline $\mathrm{BaCh}$ & $0,07+$ & 0,02 & 0,05 & $0,07+$ & 0,01 & 0,03 & 0,04 & 0,21 & $-0,04$ & $* * *$ & $* * *$ & $* * *$ & $* * *$ \\
\hline LV & $0,09+$ & $0,09+$ & $0,07+$ & $0,08+$ & 0,04 & $0,09+$ & $0,12+$ & $0,20+$ & 0,08 & $-0,01$ & $* * *$ & $* * *$ & $* * *$ \\
\hline IPG & 0,09 & 0,02 & 0,04 & $0,13+$ & 0,08 & 0,10 & 0,13 & $0,28+$ & 0,03 & 0,06 & 0,13 & $* * *$ & $* * *$ \\
\hline BRN & 0,03 & 0,04 & 0,008 & 0,02 & $-0,02$ & 0,08 & $0,16+$ & 0,02 & 0,09 & 0,06 & 0,07 & $-0,022$ & $* * *$ \\
\hline
\end{tabular}

(+) significativo $(5 \%) ; \mathrm{F}_{\mathrm{ST}}$ : 0,0 a 0,05 pode ser considerado como indicadores de baixa ou ausência de diferenciação genética; 0,05 a 0,15 indica moderada diferenciação genética; 0,15 a 0,25 indica alta diferenciação genética 
Analisando as populações do patógeno com base na distância genética entre as mesmas, houve um agrupamento de três diferentes grupos, sendo o primeiro formado por populações do Distrito Federal, o segundo por populações da Bahia e Minas Gerais e o último por populações de M. musicola do Rio Grande do Norte (Figura 14). A análise segundo o STRUCTURE revelou um $\mathrm{k}=4$, valor correlacionado melhor número de agrupamentos estimado pelo programa. Entretanto, o gráfico nos permite inferir a formação de três grupos genéticos. Cinco populações do Distrito Federal formaram o primeiro grupo, duas populações da Bahia o segundo grupo, e três populações da Bahia juntamente com a de Lavras e as duas do Rio Grande do Norte formaram o terceiro grupo (Figura 15). No gráfico, cada indivíduo no conjunto de dados é representado por uma linha vertical que é parcionada dentro de segmentos coloridos. Estes, por sua vez, representam a fração de adesão de cada indivíduo aos grupos e permite inferir a alta taxa de migrantes entre as populações. Embora as análises acima mostrem alguma relação entre a origem geográfica e a estrutura genética de $M$. musicola, o teste de Mantel não mostrou correlação entre distância genética e geográfica pois, embora o valor de $r$ tenha sido positivo, ele não foi significativo $(r=0,18, P=0,09)$.

Os valores de fluxo gênico $(\mathrm{Nm})$ medidos para os estados: Distrito Federal, Bahia e Rio Grande do Norte foram de 6,02, 1,99 e 1,72, respectivamente e estão diretamente relacionados com os valores da diversidade gênica. Como $\mathrm{Nm}$ foi calculado para analisar o fluxo gênico entre populações de cada estado, Minas Gerais foi desconsiderada uma vez que o estado foi representado por apenas uma população de M. musicola.

\subsubsection{Desequilíbrio de ligação}

Todos os locos estão em equilíbrio de Hardy-Weinberg $(P \geq 0,05)$ demostrando que as populações analisadas aderem ao esperado para uma população em EHW. Ainda segundo o índice de desequilíbrio gamético multilocus, que compara todos os locos juntos ao mesmo tempo, os valores de $r B a r D$ variaram de $-0,045$ para a 
população de $M$. musicola de Baraúna-RN a 1,0 para a população de Ipanguaçu-RN (Tabela 4). As populações de Lavras-MG, Fazenda Canaã-DF e todas as populações da Bahia, com exceção da Barra do Choça, apresentaram valores de rBarD significativamente diferentes de zero $(\mathrm{P} \leq 0,01$ ou 0,05$)$, rejeitando a hipótese de livre recombinação e revelando que os alelos não estão em equilíbrio de ligação. As demais populações não apresentaram evidências de desequilíbrio de ligação, embora os valores de $r$ BarD não sejam significativos. Isso indica que a maioria dos alelos dos locos microssatélites das populações em estudo não segregam de forma independente.



Figura 14. Dendrograma baseado na distância genética (Nei, 1978) entre as 13 populações de Mycosphaerella musicola com base na análise de 19 locos SSR. (Método = UPGMA Unweighted Pair Group Method with Arithmetic Mean). 


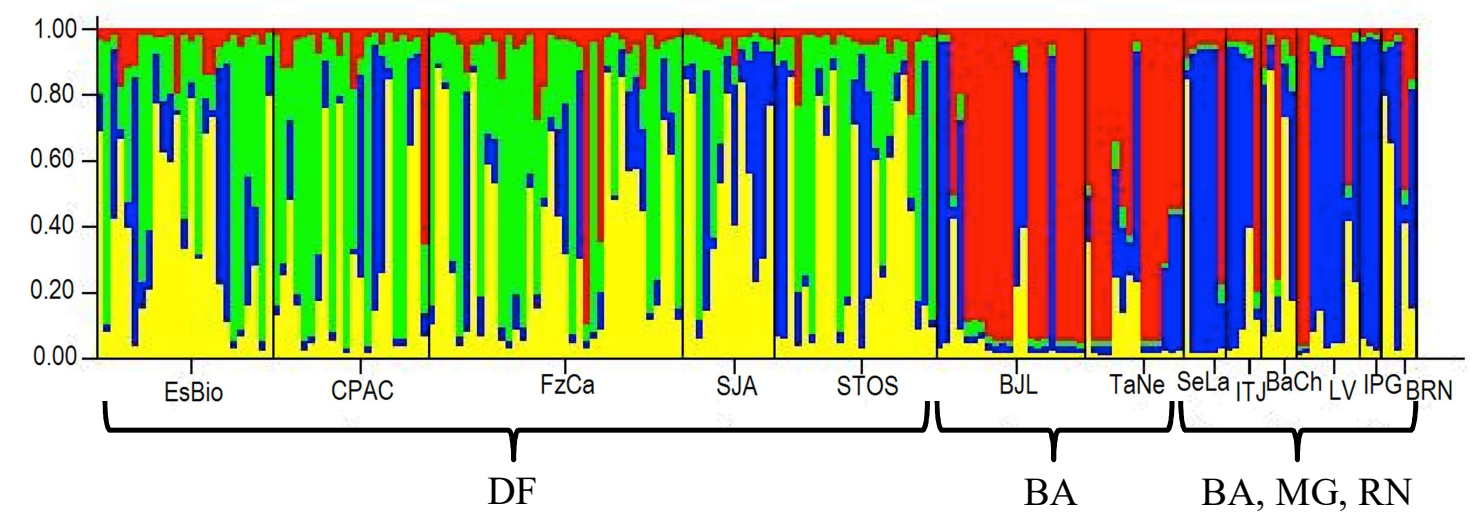

Figura 15. Análise do agrupamento das 13 populações de Mycosphaerella musicola usando 19 locos SSR, com base no programa STRUCTURE. Cada indivíduo é representado por uma barra na figura onde $\mathrm{k}$ é o número de agrupamento $(\mathrm{k}=4)$. Isolados são ordenados pela sua probabilidade de adesão ao grupo.

\subsection{Discussão}

As análises revelaram uma pequena mas significativa diferença entre populações do mesmo estado e entre populações de diferentes estados, segundo a AMOVA. Apesar da distância geográfica entre as populações de diferentes estados ser considerável, ela não foi suficiente para isolar as populações fisicamente. Embora a taxa de migrantes não tenha sido estimada, os dados apresentados mostraram muitas populações de diferentes estados compartilhando os mesmos haplótipos, inferindo-se que o grande número de migrantes distribuem novos alelos que contribuiram para a homogeneização das mesmas.

Comparando as populações aos pares, pouca à média variação genética foi observada, com valores de $F_{S T}$ variando de 0,05 a 0,28 e nenhuma correlação foi observada com a distância geográfica das populações de $M$. musicola amostradas. Hayden e colaboradores (2005) verificaram valores de $F_{S T}$ variando entre 0,04 e 0,45 para populações de M. musicola na Austrália. Para populações de M. fijiensis da Colômbia, Perea e colaboradores (2005) verificaram um variação de $F_{S T}$ de 0,07 a 
0,26. Valores mais altos de $F_{S T}$ foram encontrados por Rivas e colaboradores (2004) analisando populações de $M$. fijiensis de vários países da América Latina, encontram uma variação de 0,03 a 0,58, talvez por se tratar de amostras de diferentes países. Ainda para populações de M. fijiensis, em uma escala continental, Carlier e colaboradores (1996) encontraram valores de $F_{S T}$ variando de 0,22 a 0,58 e Halkett e colaboradores (2010) um $F_{S T}$ entre populações da África e América Central de 0,40. Embora nosso estudo tenha se limitado a amostras de M. musicola coletadas no país, dada a distância física (470 a $1900 \mathrm{~km}$ ) entre os estados analisados, espera-se uma alta diversidade entre as populações amostradas.

Para organismos que mostram uma alta habilidade para se disseminar a longas distâncias, é esperado que apresentem maior uniformidade na diversidade genética entre diferentes populações, comparados a organismos com menor habilidade de dispersão (McDonald \& Linde, 2002; Brown \& Hovmoller, 2002). Segundo McDonald \& Linde (2002), patógenos com alto fluxo gênico representam maior ameaça comparado a patógenos com menor fluxo gênico. O fluxo gênico, promovido pela dispersão de M. musicola e M. fijiensis, se deve à dispersão de conídios por gotas de chuvas a curta distância, dentro da lavoura, enquanto o movimento entre diferentes áreas de produção de banana se deve à dispersão aérea de ascósporos ejetados por peritécios (Stover \& Dickson 1976). Embora ascósporos (esporos sexuais) de $M$. musicola tenham uma grande influência na redução da diferenciação genética entre populações fisicamente distantes, a migração dos esporos sexuais em escalas maiores que $50 \mathrm{~km}$ pode ser limitada (Hayden et al., 2005). A variabilidade dos ascósporos viáveis pode estar sujeita a longos períodos de exposição a raios UV, serem afetados pela distância percorrida do ponto de origem ao de deposição e estarem dependentes da quantidade de ascósporos inicialmente ejetados (Parnell et al. 1998). Considerando esse prerrogativa, a dispersão por ascósporos pode justificar a baixa variabilidade entre populações do Distrito Federal, separadas entre si por no máximo 100km.

Uma baixa diferenciação genética entre populações de $M$. musicola de grandes áreas de produção de banana na Austrália, separadas por $1.000 \mathrm{~km}$ já foi relatada (Hayden et al., 2005). Se não pela dispersão de ascósporos, considerada um processo 
natural e gradual de dispersão, a reduzida variabilidade entre essas populações pode ter ocorrido de forma estocástica, pela ação humana, na troca de material genético de plantas contaminadas com o patógeno, promovida durante o transporte de cargas entre as regiões (Brown \& Hovmoller, 2002; Rivas et al., 2004). É importante ressaltar que os dois processos de dispersão (gradual/natural vs. estocástico/mediado pelo homem) influenciam a modelagem da estrutura populacional e são dependentes da escala geográfica considerada (Halkett et al., 2010). Dispersões a longas distâncias, promovidas por transporte de cargas contaminadas, são melhores evidenciadas em escala global ou continental com o efeito fundador gerando redução da diversidade genética entre populações separadas geograficamente. Com o passar do tempo, devido ao isolamento geográfico e processos microevolutivos, a alta diversidade genética entre as populações pode ser restituída (Brown \& Hovmoller, 2002; Halkett et al., 2010). Embora o presente estudo não tenha sido efetuado em dimensões globais ou continentais, transporte de cargas contaminadas parece ser a melhor explicação para justificar a baixa variabilidade entre as populações, uma vez que as áreas de coleta estão separadas por grandes distâncias, inviabilizando a dispersão por ascósporos.

A maior variação genética foi observada dentro das populações $(92 \%$ da variação). O número de haplótipos únicos nas populações, com correspondente diversidade genotípica e somada a igual frequência de ambos mating types fornecem evidências da ocorrência de recombinação sexual. Resultados da frequência de 1:1 de genes mating types têm sido relatados para populações de M. fijiensis no Brasil (Queiroz et al., 2013) e M. graminicola nos Estados Unidos (Gurung et al., 2011). A reprodução sexual resulta na produção de ascósporos que são extremamente importantes para o processo de dispersão, infecção e ciclo de vida do patógeno e complementa a importância dos conídios durante o processo epidemiológico. Adicionalmente, a recombinação sexual contribui para o fluxo gênico entre indivíduos e a geração de novas combinações alélicas aumentando a variabilidade genética dentro da população e consequentemente potencializando o patógeno frente a condições desfavoráveis. 
Processos microevolutivos promovem mudanças nas frequências gênicas e genotípicas e podem contribuir diretamente para a diferenciação genética dentro de populações. Dentre esses processos, a mutação é o principal mecanismo gerador de novos genes e a mais importante fonte de variabilidade genética em fungos fitopatogênicos (Camargo, 1995; Casela \& Guimarães, 1996). Desta forma, é importante ressaltar a presença desse fenômeno, juntamente com a recombinação sexual nas populações em estudo. Outro fator, não menos importante, que pode ser considerado para a elevada variabilidade genética entre indivíduos de uma mesma população é o genótipo da hospedeira (Goyeau et al., 2007; Hayden et al., 2005; Fournier \& Giraud 2008). No presente estudo, de cada local de coleta, foram amostrados M. musicola de diferentes genótipos suscetíveis de Musa, para compor uma mesma população. Como diferentes genótipos da hospedeira podem diferir em termos de grau de suscetibilidade ao patógeno, alguma pressão seletiva na população do patógeno também pode ocorrer. Essa pode ser uma justificativa para a maior variabilidade genética observada entre os indivíduos de CPAC que foram coletados de 6 diferentes genótipos de banana. Para além do âmbito desse estudo, essa correlação deve ser melhor investigada.

A análise do desequilíbrio de ligação multilocus, que compara todos os locos juntos ao mesmo tempo (Hayden et al., 2005) não corrobora com a alta diversidade genética dentro das populações. A maioria das populações apresentou baixa ou nenhuma evidência de equilíbrio de ligação. Entretanto, devido a recombinação que ocorre durante a reprodução sexual, espera-se um baixo nível de desequilíbrio gamético em populações com cruzamento ao acaso (Razavi \& Hugles, 2004). Neste caso, os alelos associados também ao acaso segregam de forma independente, característica que prediz a ocorrência de recombinação sexual.

Embora a reprodução sexual seja um processo evidente nas populações, baseado nas análises de mating type, a alta fração clonal em populações como CPAC-DF, Bom Jesus da Lapa-BA, Tancredo Neves-BA e Lavras-MG, sugere que a reprodução assexual tenha um importante papel na estrutura genética dessas populações e apoia a evidência da dispersão por conídios dentro das mesmas (Hayden et al., 2005). O 
resultado da combinação de ambos processos de reprodução é vantajoso para o organismo. Enquanto a reprodução sexual cria novos genótipos através da recombinação, frequentes ciclos de reprodução assexual podem difundir um possível indivíduo melhor adaptado, previamente selecionado por pressão seletiva. Desta forma, fungicidas convencionalmente adotados para o controle do patógeno, podem ser superados pela variabilidade genética introduzida pela recombinação e disseminada pelo processo assexual, intensificando a problemática em torno do manejo da doença (Gisi et al., 2002).

Os altos valores do número de alelos, da diversidade genética e dos índices de diversidade genotípica, para a população da Fazenda Canaã-DF, assim como os baixos valores para a população de Ipanguaçu, podem estar correlacionados com o tamanho amostral das mesmas. A diversidade genética populacional total $\left(H_{T}\right)$ variou de 0,01 a 0,93, com média de 0,49. Hayden e colaboradores (2005) avaliando a diversidade de populações de M. musicola da Austrália obtiveram uma variação da diversidade genética de 0,142 a 0,360 . Resultados similares foram relatados por Hazave \& Hughes (2004) na análise da estrutura genética de M. graminicola de Saskatchewan / Canadá e determinaram uma média de diversidade genética de 0,44. Gurung e outros (2011) relatam uma média de 0,54 quando avaliaram a diversidade genética de populações de M. graminicola nos Estados Unidos. Perea e colaboradores (2005) observaram uma média de 0,46 para populações de $M$. fijiensis de Colômbia. Embora a amplitude do $H_{T}$ no presente estudo difira do observado previamente para populações de M. musicola da Austrália, a média da diversidade genética foi similar à observada em todos os estudos relatados para o gênero.

De acordo com as análises do dendrograma e Structure, três principais grupos de populações foram formados: Distrito Federal, Rio Grande do Norte, e Bahia juntamente com Minas Gerais, inferindo-se uma estreita base genética entre os indivíduos das populações, possivelmente devido ao compartilhamento de haplótipos. A distribuição de espécies causadoras de Sigatoka pode ser influenciada pela altitude, umidade e temperatura de diferentes ambientes (Marín et al., 2003). Embora o fluxo gênico não tenha sido mensurado, todas as populações compartilharam haplótipos que 
contribuiram para a mistura dos genótipos analisados. Além disso, a proximidade entre os estados da Bahia e Minas Gerais pode ter contribuido para o agrupamento das populações.

Considerando a baixa diversidade genética entre populações, é possível predizer que as populações de diferentes estados possam exibir a mesma resistência a fungicidas. Entretanto, uma investigação mais específica sobre resistência deve ser realizada. A homogeneidade das populações de $M$. musicola de diferentes estados pode facilitar os programas de controle de Sigatoka-amarela, com regimes de aplicação de fungicidas padronizados e potencialmente aplicáveis para todas as áreas produtoras de bananeiras dos estados analisados (Gisi et al., 2002).

\subsection{Conclusão}

Os resultados apresentados corroboram com a hipótese da presença de recombinação sexual em $M$. musicola aumentando a diversidade genética entre indivíduos de uma mesma população. A baixa diversidade entre as populações pode ser resultante de um contínuo fluxo gênico entre as mesmas possivelmente porque a ação antrópica esteja contribuindo com o fluxo gênico e a homogeneização das populações, uma vez que a dispersão por ascósporos é infrequente entre grandes distâncias. 


\section{Capítulo 3. Sensibilidade de populações de Mycosphaerella musicola a fungicidas DMIs}

\section{Resumo}

Mycosphaerella musicola, agente causal de Sigatoka-amarela, é um dos principais patógenos causadores de danos em bananeiras em todo o mundo. Resistência genética é ausente ou parcial na maioria das cultivares, tornando o uso em alta frequência de fungicidas sistêmicos ou protetores, a principal medida empregada para o manejo integrado da doença. Fungicidas DMIs estão entre os mais comumente utilizados para o controle de espécies de Mycosphaerella. Estes agem inibindo a esterol 14 $\alpha$ demetilase, enzima da superfamília CYP51 envolvida na biossíntese do ergosterol, um composto essencial para a sobrevivência da célula fúngica. Informações sobre a relação de $M$. musicola com fungicidas DMIs e sobre o perfil genético de resistência do patógeno, são praticamente inexistentes. Considerando a importância do patógeno em plantações de bananeiras no Brasil, o objetivo do trabalho foi analisar a sensibilidade de M. musicola a fungicidas DMIs e verificar a presença de alterações genéticas no gene CYP51 de isolados de M. musicola. Para tanto, 48 isolados do patógeno de três diferentes áreas produtoras de bananeiras no entorno do Distrito Federal foram avaliados frente a oito fungicidas azole: epoxiconazol, pyrenifox, propiconazol, prochloraz, fluquinconazol, tebuconazol, cyproconazol e triadimenol. Parte do gene CYP51 de 12 isolados e o gene completo de 3 destes foram sequenciados e analisados quanto a presença de mudanças genéticas nas sequências dos genes codificando a proteína alvo para os fungicidas. Cinco isolados de $M$. musicola de São João da Aliança mostraram tolerância aos fungicidas tebuconazole, triadimenol e cyproconazole e um ponto de mutação no aminoácido do códon 461 foi observado nos mesmos isolados. Uma correlação entre a mutação observada e a tolerância aos fungicidas DMIs parece ocorrer nos isolados de M. musicola. 


\subsection{Introdução}

Mycosphaerella musicola (anamorfo Pseudocercospora musae), agente causador de Sigatoka-amarela, é um dos principais patógenos causadores de danos em cultivos de bananeira em todo o mundo. A doença foi primeiramente descrita na banana em Java por Zimmermann em 1902. Em seguida, foi relatada no distrito de Sigatoka na ilha de Viti Levu, em Fiji, no ano de 1912. Durante os 40 anos seguintes, ela se tornou uma séria doença epidêmica de escala global e foi identificada na Ásia, África, Américas Central e do Sul e Caribe (Meredith, 1970). Entre os principais sintomas de Sigatoka-amarela estão: necrose foliar com perdas da área fotossintética e redução no tamanho dos frutos e número de cachos.

Resistência genética é ausente ou parcial na maioria das cultivares de banana, tornando o uso em alta frequência, de fungicidas sistêmicos ou protetores, a principal medida empregada para o manejo integrado de doenças. Os resultados são os elevados custos de produção, uma vez que os gastos com fungicidas somam a maior parte do valor aplicado na lavoura e o impacto causado pelo excesso de químicos no ambiente. Adicionalmente, a atividade resulta numa possível pressão seletiva sobre a população de patógenos, contribuindo para o seleção de indivíduos resistentes que competem com a população tipo selvagem (Gasparotto et al., 2006; Heslop-Harrison \& Schwarzacher, 2007)

Fungicidas DMIs (imidazóis e triazóis), estão entre os mais comumente utilizados para o controle de patógenos fúngicos humano e de plantas. É frequente o emprego desse grupo de fungicidas em espécies de Mycosphaerella, principalmente para o controle de Mycophaerella graminicola (Zimoseptoria tritici), agente causador de Septoriose no trigo e de Mycosphaerella fijiensis, causador de Sigatoka-negra em bananeira. Para o controle de M. fijiensis o uso dos DMIs iniciou-se por volta de 1987, mas apenas em 1991 o propiconazol se tornou mais utilizado no controle da doença (Marín et al., 2003; Cañas-Gutiérrez et al., 2009). Atualmente, outros fungicidas do grupo, como difenoconazol, bitertonazol, epoxiconazol e tebuconazol são utilizados para o controle de espécies de Mycosphaerella. Contudo, resistência 
para a maioria dos fungicidas utilizados no controle de $M$. graminicola e $M$. fijiensis tem sido documentada, incluindo para outros grupos químicos tais como estrobirulinas, benzimidazóis e DMIs (Amil et al., 2007; Cañas-Gutiérrez et al., 2009).

Fungicidas DMIs, agem inibindo a esterol $14 \alpha$-demetilase, uma enzima da superfamília CYP51 envolvida biossíntese do ergosterol, um importante composto por regular o fluido na membrana e a permeabilidade das células fúngicas, sendo essencial para a sobrevivência da célula (Lepesheva \& Waterman, 2004; Cools et al., 2013). A baixa sensibilidade de patógenos fúngicos a DMI parece estar relacionada a mutações no gene CYP51. Em M. fijiensis, a resistência está correlacionada com um ou mais de sete (Y136F, A313G, Y461D, Y463D, Y463H, Y463N e Y463S) mutações pontuais na sequência do gene CYP51 que codifica a enzima esterol $14 \alpha-$ demetilase (Cañas-Gutiérrez et al., 2009).

Esse fenômeno também foi observado em outras espécies de fungos como $M$. graminicola, sendo 17 o número de alterações (substituições ou deleções) nos aminoácidos da proteína MgCYP51, relatado para a espécie em questão (Cools \& Fraaije, 2008; Cools et al., 2010). Análises da esterol 14 $\alpha$-demetilase contida em isolados de M. graminicola com diferentes variantes de CYP51 sugerem que algumas alterações podem afetar a capacidade de M. graminicola para metabolizar eburicol, o substrato de CYP51 em fungos filamentosos (Bean et al., 2009). Similarmente, mutações correspondentes à resistência a fungicidas DMIs tem sido identificadas em outros CYP51 de fungos, incluindo patógenos humanos oportunistas, como Candida albicans (Marichal et al., 1999) e Aspergillus fumigatus (Ferreira et al., 2005).

O controle de Sigatoka-amarela também está relacionado a intensas aplicações de fungicidas DMIs. Entretanto, a baixa sensibilidade de M. musicola a esses químicos ainda é pouco relatada, com registros encontrados apenas para propicanazol (Peterson et al., 2002). Mesmo junto à FRAC Banana Working Group (www.frac.info), as informações sobre a relação de M. musicola com fungicidas DMIs são praticamente inexistentes. O mesmo se aplica aos registros sobre análises moleculares da resistência do fungo com mutações nos genes correspondentes. A 
ausência de informações sobre o perfil genético de resistência de $M$. musicola aos fungicidas adotados justifica a condução de pesquisas calcados na biologia molecular e no comportamento do patógeno frente ao princípios ativos dos fungicidas. Isso se torna uma importante estratégia para conter o avanço de populações resistentes bem como para reduzir a frequência de aplicações de fungicidas e minimizar as consequências do mal uso desses agentes químicos.

Considerando que M. musicola ainda é a espécie de Mycosphaerella de maior ocorrência no Brasil, provocando elevadas perdas nos cultivos de banana, o objetivo do trabalho foi analisar a sensibilidade de M. musicola a fungicidas DMIs e verificar a presença de alterações genéticas em homólogo de CYP51 de M. musicola.

\subsection{Material e Métodos}

\subsubsection{Origem e identificação dos isolados de M. musicola}

Os isolados de $M$. musicola em análise foram coletados de folhas de bananeiras mostrando sintomas típicos de Sigatoka-amarela, de três zonas agroecológicas no entorno do Distrito Federal (Tabela 9). As áreas de cultivo foram manejadas com controle baseado na aplicação alternada de fungicidas do grupo das estrobilurina, inibidores da respiração mitocondrial (Gisi et al., 2002) e DMI.

O DNA genômico foi extraído do micélio de todas as culturas monospóricas cultivadas em placas de Petri em meio V8, seguindo o protocolo de extração de DNA de Doyle \& Doyle (1987), com algumas modificações. Os isolados foram identificados como sendo M. musicola a partir dos dados de sequências da região ITS (Internal Transcribed Spacer) do DNA ribossomal, usando primers universais ITS4 e ITS5 (White et al., 1990). Para assegurar a identificação molecular, parte dos genes da actina (ACT) (Carbone \& Kohn, 1999) e da histona H3 (HIS) (Crous et al., 2004) foram amplificados. Protocolo e condições de PCR, assim como o alinhamento dos

dados das sequências foram tratados e analisados como descrito em Crous e colaboradores (2004). 
Tabela 9. Identificação e fontes dos isolados de Mycosphaerella musicola.

\begin{tabular}{|c|c|c|c|}
\hline Localidade & \multicolumn{2}{|c|}{$\begin{array}{l}\text { Variedades } \\
\left(\mathrm{n}^{\circ} \text { de isolados }\right)\end{array}$} & Total de isolados \\
\hline 1. Embrapa Cerrados - Planaltina (CPAC) & $\begin{array}{l}\text { Phia17 } \\
\text { Phia02 } \\
\text { Maravilha } \\
\text { Thap Maeu } \\
\text { Grande Nain }\end{array}$ & $\begin{array}{r}(4) \\
(4) \\
(4) \\
(4) \\
e(4)\end{array}$ & 20 \\
\hline $\begin{array}{l}\text { 2. Água Fria de Goiás - São João da Aliança } \\
\text { (SJA) }\end{array}$ & $\begin{array}{l}\text { Prata } \\
\text { Nanica }\end{array}$ & $\begin{array}{l}\text { (3) } \\
\text { (3) }\end{array}$ & 6 \\
\hline $\begin{array}{l}\text { 3. Núcleo Rural Sobradinho } 1 \text { - Chácara } \\
\text { Santos (STOS) }\end{array}$ & $\begin{array}{l}\text { Prata } \\
\text { Nanica }\end{array}$ & $\begin{array}{l}(17) \\
(5)\end{array}$ & 22 \\
\hline Total & - & & 48 \\
\hline
\end{tabular}

\subsubsection{Sensibilidade de $M$. musicola a fungicidas DMIs}

A análise da sensibilidade dos isolados a fungicidas DMIs foi realizada no laboratório da Rothamsted Research - Inglaterra. Um total de 97 isolados de $M$. musicola foram recuperados de preservações em papéis filtro. Desse total, 48 indivíduos de três diferentes localidades (Tabela 9), apresentando os maiores diâmetros de colônias foram seleciandos. O número de indivíduos analisados foi limitado pela disponibilidade de materiais e pelo tempo para a execução dos experimentos, que foram conduzidos em duas etapas. A primeira consistiu de um bioensaio, conforme protocolo de Mullins et al. (2011), utilizando os 48 isolados de M. musicola para a seleção de indivíduos mostrando algum sinal de sensibilidade aos DMIs, empregando os fungicidas epoxiconazole e tebuconazole assim como uma estrobilurina: azoxystrobin e um benzimidazol: carbendazim. Para tanto, alíquotas de $100 \mu \mathrm{L}$ de meio líquido Sabouraud Dextrose, somadas a decrescentes concentrações de azoxystrobin, epoxiconazole $(18,75,4,687,1,171,0,292,0,073,0,018,0,0045$, 0,0011, 0,00028, 0,0000715 $\left.\mathrm{mg} \mathrm{L}^{-1}\right)$, tebuconazole e carbendazim $(25,8,333,2,777$, 0,9259, 0,3086, 0,1028, 0,0342, 0,01143, 0,00381, 0,00127 $\mathrm{mg} \mathrm{L}^{-1}$ ), foram 
adicionadas em poços de microplacas. Dois fragmentos miceliais de aproximadamente $1 \mathrm{~cm}$ de diâmetro de cada cultura fúngica, com 20 dias de crescimento em meio $\mathrm{V} 8$ a $25^{\circ} \mathrm{C}$, foram macerados em cadinho com $3 \mathrm{~mL}$ de água destilada esterilizada. A suspensão foi transferida para tubo Falcon de $15 \mathrm{~mL}$ e diluída na proporção de 1:20. Alíquotas de $100 \mu \mathrm{L}$ dessa suspensão foram adicionadas a cada poço das placas que em seguida, foram incubadas por sete dias a $25^{\circ} \mathrm{C}$ (Figura 16). O crescimento micelial foi medido por absorbância a $630 \mathrm{~nm}$ utilizando um leitor de microplacas Fluostar Optima (BMG Labtech GmbH, Offenberg, Germany). A sensibilidade ao fungicida foi determinada como concentração efetiva $50 \%\left(\mathrm{EC}_{50}\right)$, utilizando uma relação dose-resposta de acordo com os programa BMG Labtech Optima.

Os isolados de M. musicola selecionados na primeira etapa, alguns por apresentarem menor sensibilidade ao fungicidas DMIs e outros como controle, foram avaliados em um segundo bioensaio, frente a oito fungicidas do grupo DMIs, nas seguintes concentrações: epoxiconazol, pyrenifox, propiconazol, prochloraz e fluquinconazol (1, 0,4, 0,16, 0,064, 0,0256, 0,01024, 0,004096, 0,001638, 0,000655, 0,000262, 0,000105 $\mathrm{mg} \mathrm{L}^{-1}$ ), tebuconazol e cyproconazol (10, 4, 1,6, 0,64, 0,256, 0,1024, 0,04096, 0,016384, 0,006554, 0,002621, 0,001049 $\left.\mathrm{mg} \mathrm{L}^{-1}\right)$ e triadimenol (50, 20, 8, 3,2, 1,28, 0,512, 0,2048, 0,08192, 0,032768, 0,013107, 0,005243mg L-1). As análises foram conduzidas em duplicatas e as etapas do bioensaio seguiram o protocolo descrito anteriormente. 

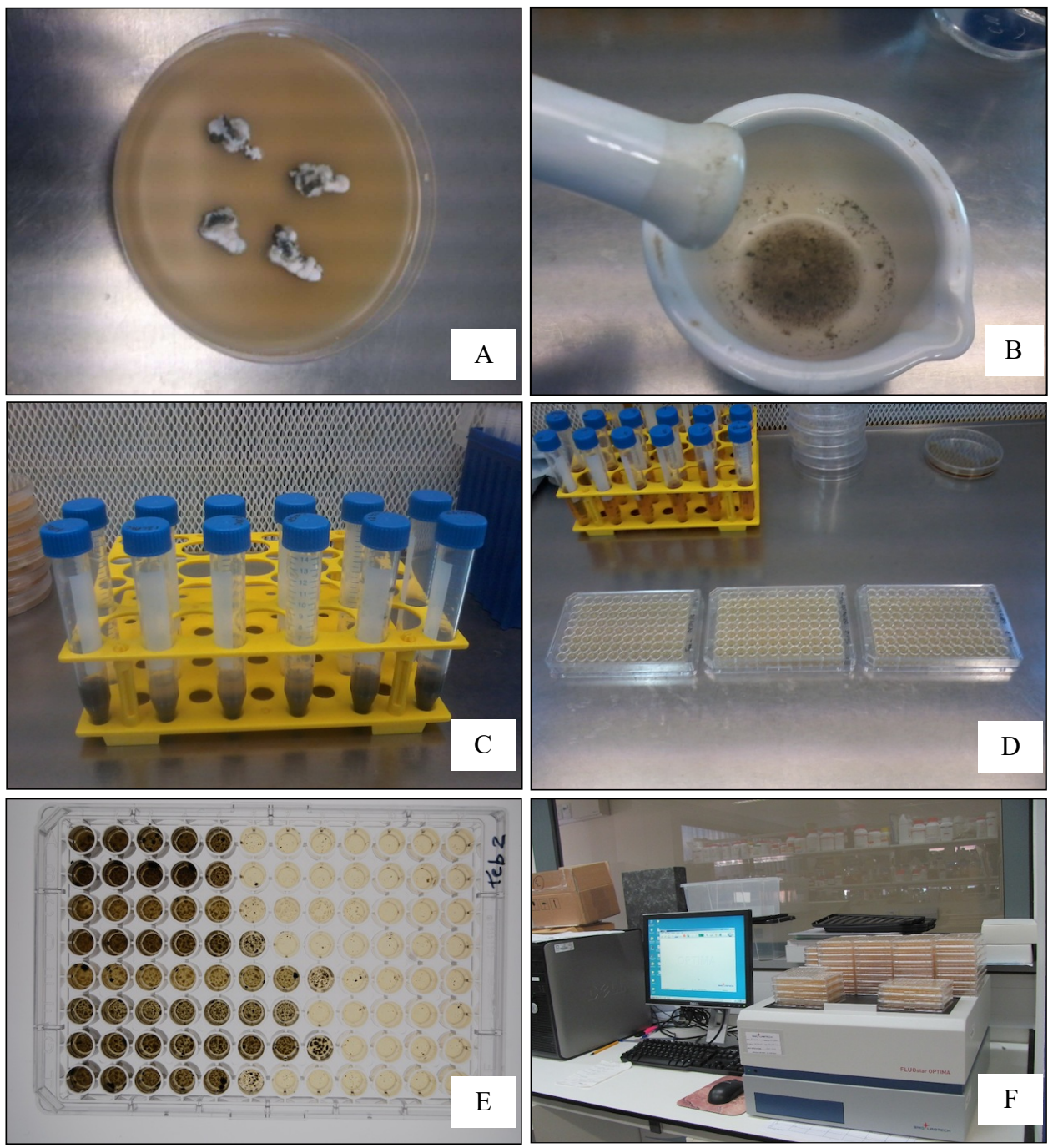

Figura 16. Etapas do bioensaio para a análise da sensibilidade dos isolados de Mycosphaerella musicola a fungicidas. A e B, maceração da cultura fúngica com 20 dias de crescimento. C e D, preparo da suspensão dos fragmentos miceliais para distribuição em microplacas. E e F, leitura das microplacas após sete dias de incubação. 


\subsubsection{Amplificação e sequenciamento de genes alvo de fungicidas}

Alterações genéticas do gene CYP51 alvo de fungicidas DMIs, de isolados de M. musicola, foram verificadas em sequências completas e em parte do gene amplificadas usando os conjuntos de primers: MMFOR2 (CAA TGG GA/TC TCC TCC AGG A) / MMREV1 (TTG ACG CTG CCA/G TCC/G ACA TTG TA), MMFOR1 (GGA GGA GCG CTT TTG CTT CGG CTT) / MMREV5 (TAT GGA CAC GCC GAT AAA GAT GCT) e MMFOR8 (CGA CAC AGG TGC ATC GGT GAG CA) / MMREV8 (ATT TCT TTT CTC TCC TCT CCC ATC), desenhados a partir de sequências conhecidas para estes locos em M. graminicola e M. fijiensis, usando os dados dos genomas disponíveis. As PCRs foram conduzidas conforme o protocolo descrito por Fraaije et al. (2012), para um volume de $20 \mu \mathrm{L}$, contendo $20 \mathrm{ng}$ de DNA, tampão easy-A $10 \mathrm{X}, 0,2 \mathrm{mM}$ de dNTP, $0,4 \mu \mathrm{M}$ de cada primer e $0,5 \mathrm{U}$ de Easy A high-fidelity PCR cloning enzyme (Agilent). Os tubos para PCR foram acondicionados em termociclador (Esco Swift MaxPro) e a reação conduzida nas seguintes condições: 1 ciclo para etapa inicial de desnaturação $\left(94^{\circ} \mathrm{C}\right.$ por 2 minutos), seguido de 40 ciclos com uma etapa de desnaturação $\left(92^{\circ} \mathrm{C}\right.$, por 10 segundos $)$, uma de anelamento $\left(60^{\circ} \mathrm{C}\right.$ por 20 segundos) e uma de extensão $\left(72^{\circ} \mathrm{C}\right.$ por 2 minutos) e um último ciclo de extensão final $\left(72^{\circ} \mathrm{C}\right.$ por $\left.5 \mathrm{~min}\right)$. A eletroforese foi conduzida em gel de agarose $1,0 \%$ e TBE $1 \mathrm{X}$. Em cada poço foi adicionado 2,0 $\mu \mathrm{L}$ do produto da PCR, mais 3,0 $\mu \mathrm{L}$ de tampão de corrida e no primeiro poço continha $3 \mu \mathrm{L}$ de marcador easy ladder $(100 \mathrm{pb})$. A corrida ocorreu a $110 \mathrm{~V}$ (voltagem constante) por aproximadamente 20 minutos e os produtos foram visualizados e quantificados no transluminador (UV - $254 \mathrm{~nm}$ ). Os produtos da PCR foram purificados e sequenciados pelo método Sanger em um único sentido. As sequências foram alinhadas (programa Geneious) à sequência do gene CYP51 de M. fijiensis depositada no banco de dados (http://genome.jgi-psf.org/Mycfi2/Mycfi2.home.html) e checadas para a presença de mudanças genéticas nas sequências codificantes e regulatória (promotora) dos genes codificando a proteína alvo para ação dos fungicidas. 


\subsection{Resultados}

\subsubsection{Sensibilidade de $M$. musicola a fungicidas DMIs}

Os resultados da análise da sensibilidade de isolados de M. musicola aos fungicidas tebuconazole, carbendazim, azoxystrobin e epoxiconazole permitiram classificar os isolados em dois grupos: sensíveis e tolerantes, semelhante ao realizado por Canãs-Gutiérrez e outros (2009) e Chong e colaboradores (2011). Cinco dos seis isolados de M. musicola provenientes de São João da Aliança mostraram um comportamento diferenciado dos demais, frente ao fungicida tebuconazole apresentando tolerância a ação do fungicida, com valores de $\mathrm{EC}_{50}$ variando entre 0,1 a $0,3 \mathrm{mg} \mathrm{L}^{-1}$. Para os demais químicos avaliados, os valores de $\mathrm{EC}_{50}$ foram iguais ou menores que $0,05 \mathrm{mg} \mathrm{L}^{-1}$ classificando os isolados como sensíveis aos fungicidas (Figura 17).

Os 12 isolados de M. musicola, selecionados do primeiro bioensaio (seis de São João da Aliança, 3 do CPAC e 3 da Fazenda Santos), mostraram comportamento heterogêneo frente aos oito fungicidas DMIs avaliados no segundo bioensaio (Figura 18, 19 e 20). Os mesmos cinco isolados de São João da Aliança, comparados aos demais, apresentaram tolerância aos fungicidas tebuconazole, triadimenol e cyproconazole com valores de $\mathrm{EC}_{50}$ variando de 0,11 a $0,3 \mathrm{mg} \mathrm{L}^{-1}$ para tebuconazole, 0,6 a $1,7 \mathrm{mg} \mathrm{L}^{-1}$ para triadimenol e 0,08 a $0,29 \mathrm{mg} \mathrm{L}^{-1}$ para cyproconazole (Tabela 10). Os isolados com valores de $\mathrm{EC}_{50}$ menores que $0,11 \mathrm{mg} \mathrm{L}^{-1}$ para tebuconazole, 0,6 $\mathrm{mg} \mathrm{L}^{-1}$ para triadimenol e $0,08 \mathrm{mg} \mathrm{L}^{-1}$ para cyproconazole foram considerados sensíveis aos fungicidas. Embora esses cinco isolados de M. musicola de São João da Aliança tenham mostrado diferenças dos demais isolados frente aos cinco DMIs restantes (epoxiconazole, pyrenifox, propiconazole, prochloraz e fluquinconazole), eles exibiram valores de $\mathrm{EC}_{50}$ menores que $0,05 \mathrm{mg} \mathrm{L}^{-1}$, mostrando sensibilidade aos fungicidas. Os resultados permitem predizer um possível padrão de sensibilidade cruzada entre os isolados para os fungicidas tebuconazole, triadimenol e cyproconazole. 




Figura 17. Sensibilidade de isolados de Mycosphaerella musicola aos fungicidas tebuconazol, carbendozim, azoxystrobin e epoxiconazol. 

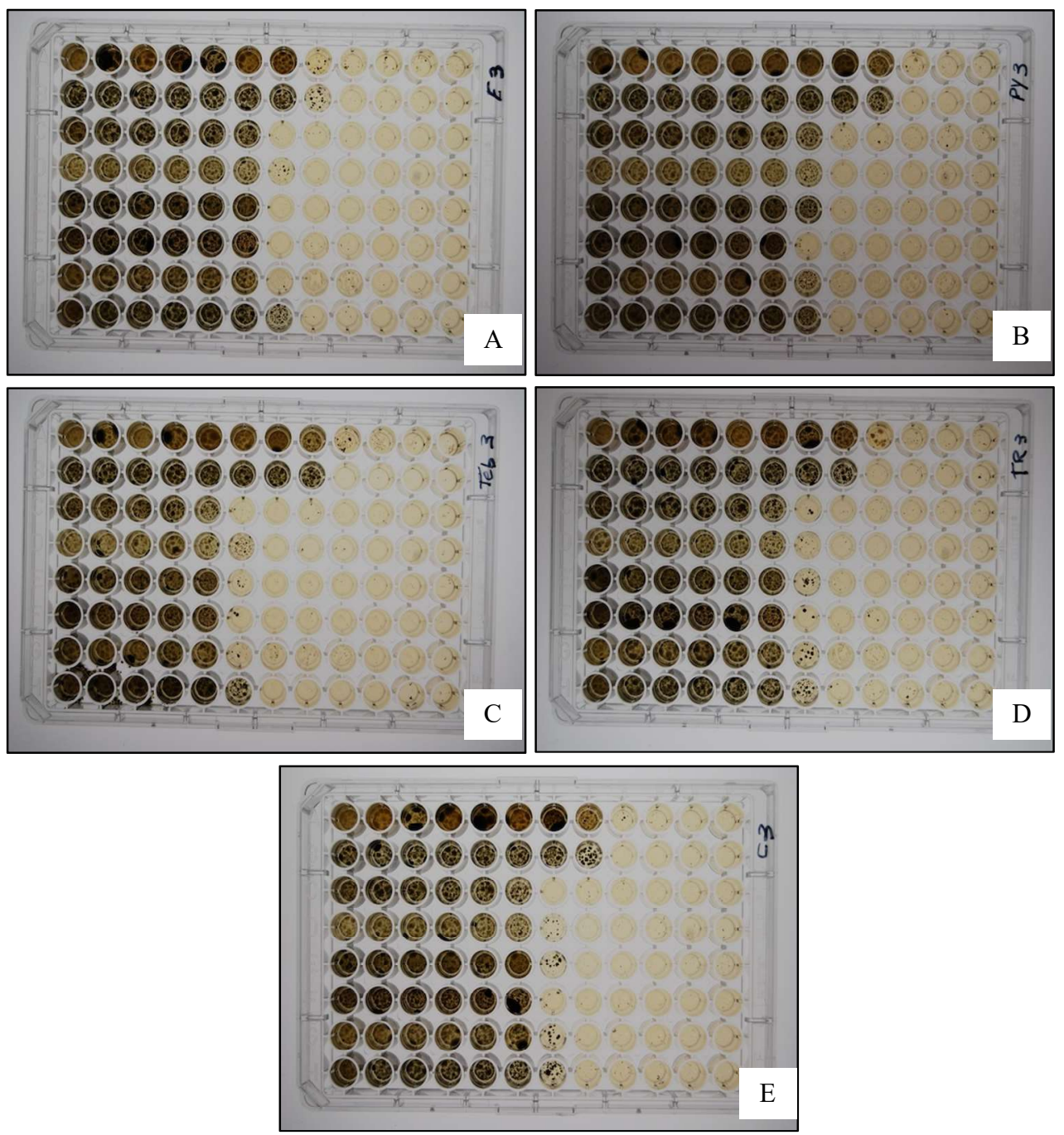

Figura 18. Sensibilidade de isolados de Mycosphaerella musicola à diferentes concentrações (poços das colunas de 1 a 12) de fungicidas DMIs. A, epoxiconazol e B, pyrenifoz (1, 0,4, 0,16, 0,064, 0,0256, 0,01024, 0,004096, 0,001638, 0,000655, 0,000262, 0,000105 $\left.\mathrm{mg} \mathrm{L}^{-1}\right) . \mathrm{C}$, tebuconazol (10, 4, 1,6, 0,64, 0,256, 0,1024, 0,04096, 0,016384, 0,006554, 0,002621, $\left.0,001049 \mathrm{mg} \mathrm{L}^{-1}\right)$. D, triadimenol $(50,20,8,3,2,1,28,0,512,0,2048,0,08192,0,032768$, 0,013107, 0,005243mg L $\mathrm{m}^{-1}$ ). E, cyproconazol (10, 4, 1,6, 0,64, 0,256, 0,1024, 0,04096, 0,016384, 0,006554, 0,002621, 0,001049 $\mathrm{mg} \mathrm{L}^{-1}$ ). Poços das fileiras: 1 e 2: isolados de São João da Aliança; 3, 4 e 5: isolados da Fazenda Santos; 6, 7 e 8: isolado de CPAC. 

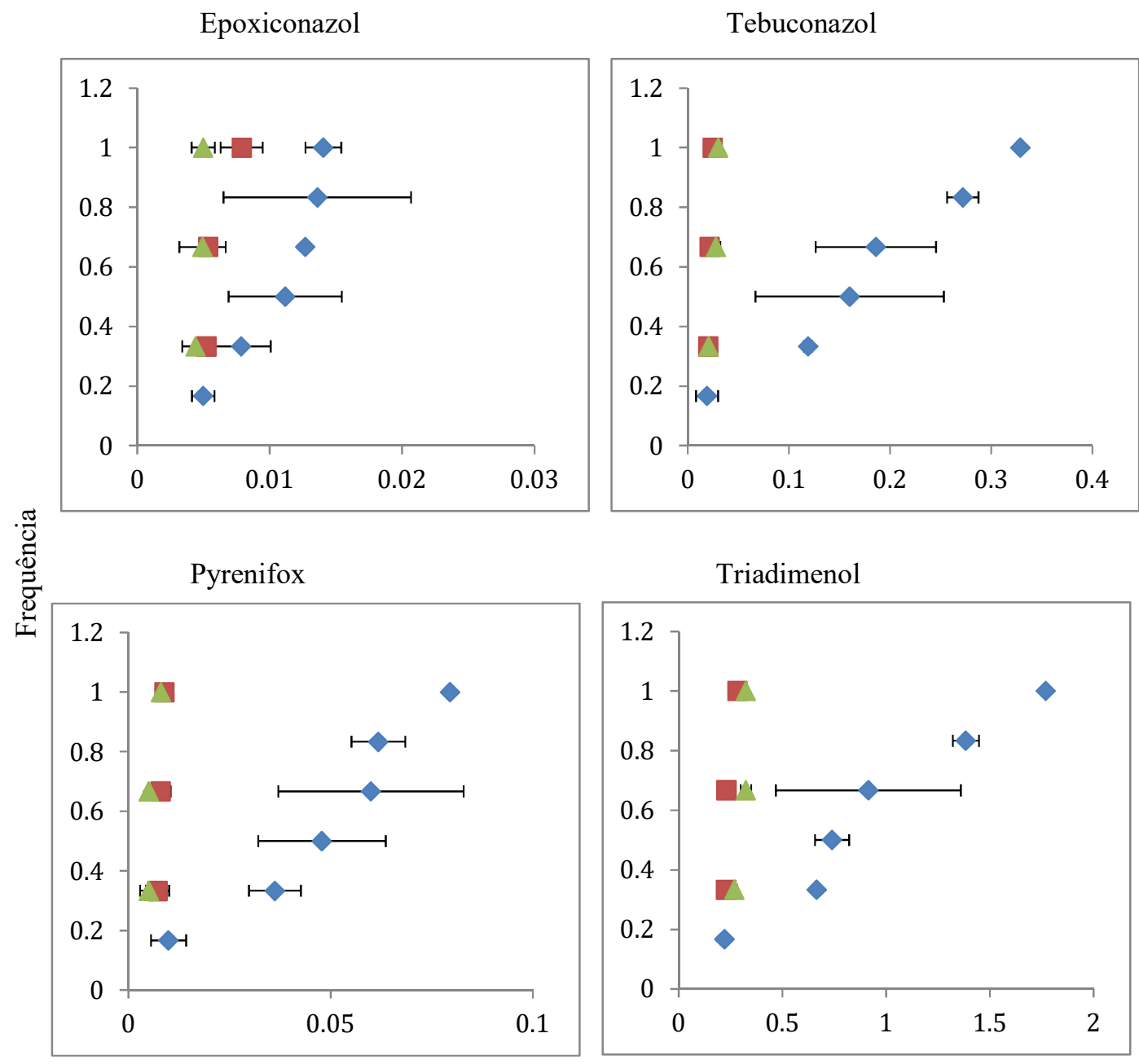

$\mathrm{EC}_{50}\left(\mathrm{mg} \mathrm{L}^{-1}\right)$



São João da Aliança

Fazenda Santos

Figura 19. Sensibilidade de isolados de Mycosphaerella musicola aos fungicidas DMIs: epoxiconazole, tebuconazole, pyrenifox e triadimenol. Barras horizontais representam o desvio padrão das médias dos valores de $\mathrm{EC}_{50}$. 

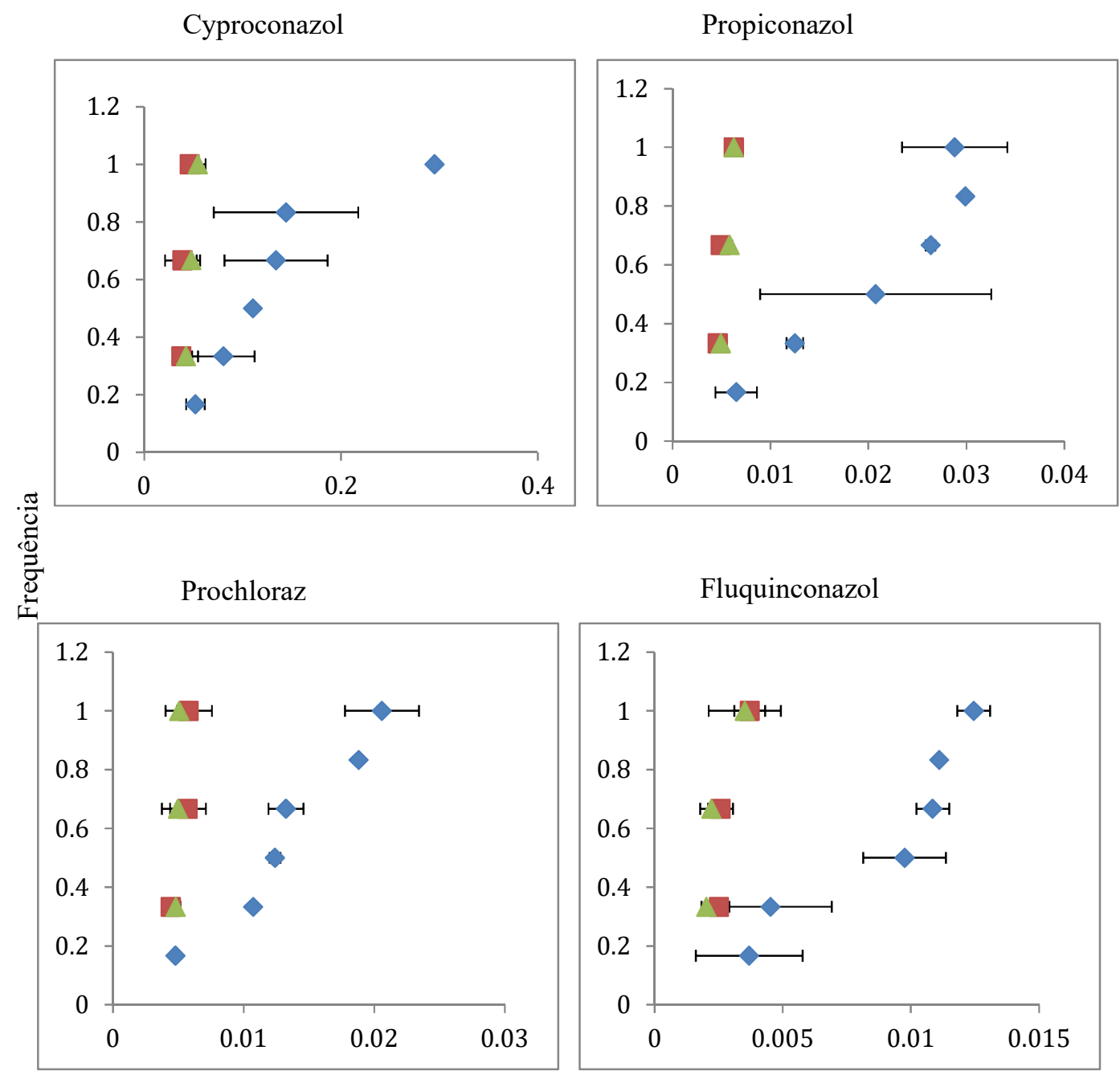

$\mathrm{EC}_{50}\left(\mathrm{mg} \mathrm{L}^{-1}\right)$

\section{CPAC}

São João da Aliança

Fazenda Santos

Figura 20. Sensibilidade de isolados de Mycosphaerella musicola aos fungicidas DMIs: cyproconazole, propiconazole, prochloraz e fluquinconazole. Barras horizontais representam o desvio padrão das médias dos valores de $\mathrm{EC}_{50}$. 
Tabela 10. Sensibilidade a fungicidas e mutação encontrada no gene CYP51 dos isolados de Mycosphaerella musicola analisados.

\begin{tabular}{|c|c|c|c|c|c|c|c|c|c|c|}
\hline \multirow{2}{*}{ Identificação } & \multirow{2}{*}{$\begin{array}{l}\text { Locais de } \\
\text { coleta }\end{array}$} & \multirow{2}{*}{$\begin{array}{c}\text { MmCYP51 } \\
\text { (substituição) }\end{array}$} & \multicolumn{8}{|c|}{$\mathrm{EC}_{50}\left(\mathrm{mg} \mathrm{L}^{-1}\right)^{*}$} \\
\hline & & & Epoxiconazol & Tebuconazol & Pyrenefox & Triadimenol & Cyproconazol & Propiconazol & Prochloraz & Fluquinconazol \\
\hline (2) Mm_PRATA_P3F1M & \multirow{6}{*}{$\begin{array}{c}\text { São João } \\
\text { da } \\
\text { Aliança }\end{array}$} & Y461N & 0,01405 & 0,16010 & 0,04785 & 0,73950 & 0,11050 & 0,02635 & 0,00975 & 0,01325 \\
\hline (4) Mm_PRATA_P6F1P & & Y461N & 0,00785 & 0,11900 & 0,03625 & 0,66600 & 0,08050 & 0,01250 & 0,00452 & 0,01075 \\
\hline (6) Mm_PRATA_P10F1M & & Y461N & 0,01359 & 0,18600 & 0,06000 & 0,91450 & 0,13395 & 0,02075 & 0,01085 & 0,01240 \\
\hline (9) Mm_NANICA_P2F1M & & Não & 0,00497 & 0,01920 & 0,00994 & 0,22050 & 0,05210 & 0,00650 & 0,00369 & 0,00479 \\
\hline (12) Mm_NANICĀ_P7F1P & & Y461N & 0,01270 & 0,32900 & 0,07950 & 1,77000 & 0,29500 & 0,02990 & 0,01110 & 0,01880 \\
\hline (13) Mm_NANICA_P8F1P & & Y461N & 0,01117 & 0,27200 & 0,06180 & 1,38500 & 0,14415 & 0,02880 & 0,01245 & 0,02060 \\
\hline (12) Mm_PRATA_P8F1P & \multirow{3}{*}{$\begin{array}{l}\text { Fazenda } \\
\text { Santos }\end{array}$} & Não & 0,00522 & 0,02155 & 0,00893 & 0,23100 & 0,03775 & 0,00463 & 0,00257 & 0,00580 \\
\hline (18) Mm_PRATA_P11F1M & & Não & 0,00788 & 0,02470 & 0,00806 & 0,22950 & 0,03890 & 0,00625 & 0,00251 & 0,00574 \\
\hline (22) Mm_NANICĀP5F2P & & Não & 0,00536 & 0,02045 & 0,00722 & 0,28400 & 0,04645 & 0,00491 & 0,00371 & 0,00443 \\
\hline (7) Mm_P17F2P & \multirow{3}{*}{ CPAC } & Não & 0,00439 & 0,02075 & 0,00510 & 0,26950 & 0,04235 & 0,00493 & 0,00221 & 0,00480 \\
\hline (8) Mm_P17F2M & & Não & 0,00498 & 0,02790 & 0,00509 & 0,32400 & 0,04790 & 0,00585 & 0,00202 & 0,00508 \\
\hline (12) $\mathrm{Mm}_{-} \mathrm{P} 02 \mathrm{~F} 2 \mathrm{M}$ & & Não & 0,00493 & 0,03030 & 0,00807 & 0,32400 & 0,05470 & 0,00626 & 0,00352 & 0,00498 \\
\hline
\end{tabular}

(*) Valores de $\mathrm{EC}_{50}$ é a média de dois experimentos independentes. Não - ausência de mutação. 


\subsubsection{Amplificação e sequenciamento de genes de proteínas alvo dos fungicidas}

A amplificação de parte do gene CYP51 dos 12 isolados de M. musicola avaliados no segundo bioensaio, geraram fragmentos de aproximadamente 1.500 pares de base (Figura 21).

O alinhamento múltiplo destes fragmentos sequenciados revelou um polimorfismo de nucleotídeo único (SNP) para todos os cinco dos seis isolados de $M$. musicola de São João da Aliança com tolerância aos fungicidas tebuconazole, triadimenol e cyproconazole (Tabela 10, Figura 22). Nenhuma alteração foi observada para os demais isolados sensíveis aos fungicidas. A partir do alinhamento da sequência consensus do gene CYP51 desses isolados à sequência de $M$. fijiensis a alteração foi identificada como sendo uma substituição no aminoácido do códon 461 .

O alinhamento do gene CYP51 completo de um dos cinco isolados de São João da Aliança com M. fijiensis permitiu observar a conservação do gene entre as duas espécies de Mycosphaerella e a ausência de novos pontos de mutação (Figura 23).

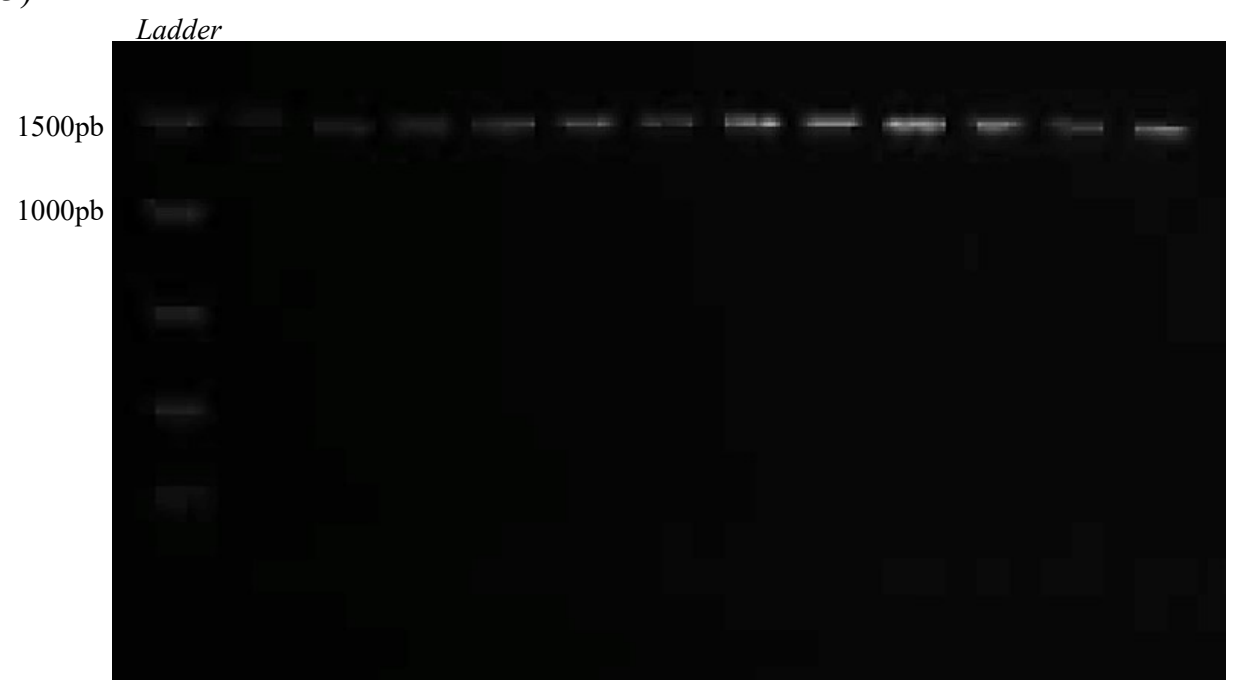

Figura 21. Amplificação de parte do gene CYP51 dos isolados de Mycosphaerella musicola, gerando fragmentos de aproximadamente $1.500 \mathrm{pb}$. Coluna 1: marcador easy Ladder. Coluna 2 à 13: 6 isolados de SJA, 3 de CPAC e 3 de STOS, respectivamente. 


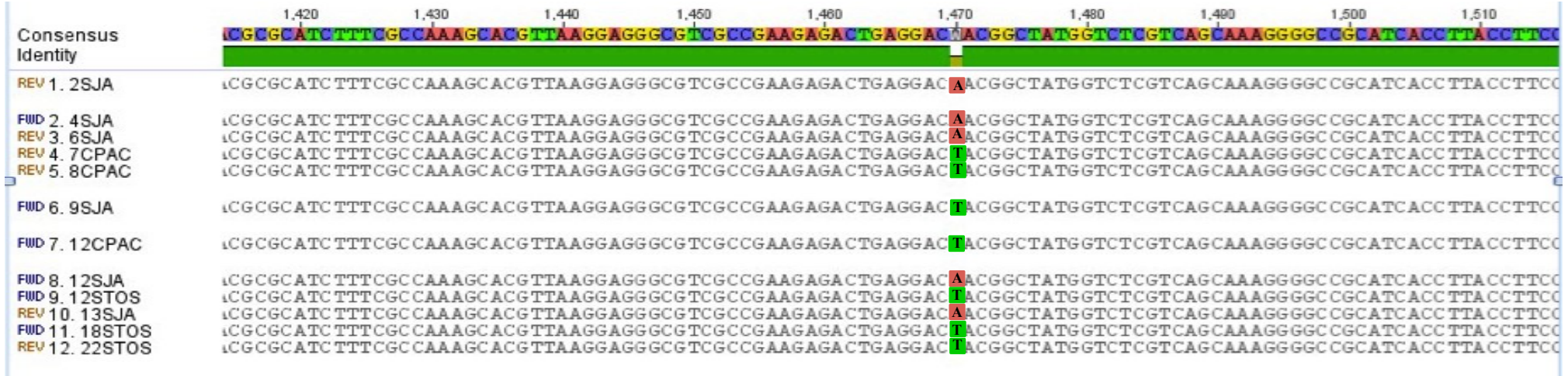

Figura 22. Alinhamento entre nucleotídeos do gene CYP51 dos 12 isolados de Mycosphaerella musicola: 6 isolados de SJA, 3 de CPAC e 3 de STOS. 
M. fijiensis

M. musicola

M.fijiensis

M. musicola

M.fijiensis

M. musicola

M. fijiensis

M.musicola

M. fijiensis

M. musicola

M. fijiensis

M. musicola

M.fijiensis

M. musicola

M.fijiensis

M.musicola

M. fijiensis

M.musicola

M. fijiensis

M.musicola

M.fijiensis

M.musicola

M. fijiensis

M.musicola

M. fijiensis M.musicola

M.fijiensis M.musicola

M.fijiensis

M.musicola

M. fijiensis

M.musicola

M.fijiensis

M.musicola

M. fijiensis M.musicola

M. fijiensis

M. musicola

M. fijiensis

M. musicola

M. fijiensis

M. musicola

M. fijiensis M.musicola
1 TGCTTCGGCTTACGGTTCGGCAATCGAGTGAGGTCGAGTCTACCTCAAGATTCTGGCATT 6

1 TGCtTCGgCtTACGGCTCGGCAGTCGCATGTGAACGAAGATAAGTGAAGA--------T 51

61 TTGGCCAGCAACTGGGAGCGCCGCGATGTATGACTCTGCTATACATCTCGAGCAGAGCTG 120

52 TtGGCCAGCATGTGGAAAGGCGGCGGCACATGGCTCTGCTGTATGGCTCGAG-------- 103

121 GATATTTGCAGACCAATGGTCTTTCTCTAGCACCGAATGCCGAGCGTCTTGTATCGAGC 180 $104-------$ GTCGAGGAGTGATC------------AA-GCAGAGC-----GCATCAGGC 135

181 GATCAGAGGC--ATGCGACC-----TCCCACTCAACCTGTGATCTAGCCAT---CT---- 226 136 CGTTGAAGGCATATTCTACCTCATCTCGCACTCCACCAGACATCCAGCCATAGTCTAACG 195

227 -CGCCGACAT-CCCAAGGTCATATCGCAGGGCGTCAGTTCCCCATACTCCGTGCATCAGA 284 196 CCGCGGAGATGCCCATGGCCA-GGCGAAAGCTGTCAGTATGGCATA-TC---GAA---GA 247

285 GGGAAATATGTGCGACAGAAACATCACCTCCGGAG-...-....-.GGCAATTGCAACGC 333 248 CGG-----CGGTGACGGAAGCATCTTCTTCTGAGCCTTGAGGTTAGCCAGTTCCAGTAC 301

334 GACTTCGCGAGATGGTCAGATGATGGTTGGACCCTTGGACCCTCGCAATTGATGAGAAG 393 302 GACTTCGCTGTATTGCCCGCA------CCGCACCCTGCCACCCTCGCAGTTTGTGTGAAG 355

394 CAGGGGTGTCCCGTTCCTGCATGACTAGCGCCAAAAAGTGACGCGAATGCCGAAATGTTA 453 356 CAGGGGTCTCCCGTTCCTGCATGACTAGCGTCAAAAAGTGACGCGAGCTTCGAAATGTTA 415

454 AATCTCGTACGATAGCACCTGCCC_.........ATGGACCACTCGAACCACACTGAAG 502 416 AAtCTCGTACGATtgCACCTGCCCATAATATTGGAATGGGCCACTCGAACCACCCCCAAG 475

503 GGTAATC-ATTCAAGATCTTGGTGATTTGG---CCTAACCCCCTACACCAACATCAACAT 558 476 GGTAATCAAATCAACATCGTGTTGGTATGGTGACTTGATCCTCTCCATCGACATCACCAC 535

559 CACTGACTCCGCGCAATGGGACTCCTCCAGGACGCCGCGGCGCTTTTCGACGCGCAATTT 618 536 CGCTGACTCCGCGCCATGGGTCTGCTCCAGGACGTGGCCGCCGTCTTTGACGCGCATTTT 595

619 GGCCAGATAGCGACATGGAAACTAGTCCCCCTCGGCTTCAGCATCTTCTTCGCCGTATCC 677 596 GGCCAGACAGCAACCTGGAAACTCGTTCTCCTCGGCTTCAGCATCTTTATCGGCGTGTCC 655

678 GTGTTGCTTAACGTGTTGCGCCAGCTGCTTTTCAGAAATCCAAACGAACCTCCGCTAGTA 737 656 ATATTGCTTAACGTGTTGCGACAACTACTGTTCAGAAATCCAAACGAGCCGCCACTGGTC 715

738 TTCCACTACGTGCCCTTCATTGGCAGCACTATCTCCTATGGCATCGACCCCTACAAGTTC 797 716 TTCCACTATGTGCCCTTCATCGGCAGCACTATCTCCTATGGCATCGACCCGTACAAGTTC 775

798 TTCTTCGCCTGCCGTCAAAAATACGGAGATTGCTTCACTTTCATCCTCCTTGGCAAGAAG 857 776 тTCTTCGCCTGTCGCCAAAAATATGGAGATTGTTTCACCTTCATCCTCCTGGGCAAGAAG 835

858 ACCACCGTGGTGCTGGGGACTAAAGGCAACGACTTTATCTTGAATGGAAAGCTCAAGGAC 917 836 ACCACTGTCGTGCTAGGAACCAAAGGCAATGACTTTATTCTGAATGGAAAGCTCAAGGAC 895

918 GTCAATGCCGAGGAGATCTATAGCCCACTTACTACGCCAGTATTCGGCACAGATGTCGTC 977 896 GTGAACGCAGAGGAGATTTACAGTCCACTCACGACGCCAGTATTTGGTACGGATGTCGTC 955

978 TACGATTGTCCCAATTCGAAGCTCATGGAGCAGAAGAAGGTGCGT-GCACACAATAAGCT 1036 956 TACGATTGTCCCAATTCGAAGCTCATGGAGCAGAAGAAGGTATGTTGGTCACGTTCTGCG 1015

1037 GGATTTATGACAATGCTAA-CTTATACAGTTCGTCAAATATGGTCAGTGACTT------- 1089 1016 GTAAAACTG-CAATGCTAATATTGTACAGTTTGTCAAATATGGTCAGTCACCTCCGCACA 1074

$1090-----$ GACTC----CGC-CGCGTCTGAGACAGCGCTCTCAACAT-GAGCTTCCACTTTG 1136 1075 GCAAGACACTCTAAGCTCGCGCGTCATGGATGGCACTCT-AGCATCGGACTTTCACTTCA 1133

1137 GAGCGATACACTTGCTAA-CCTGCGCCTCCAGGCCTCACCTCCTCCGCCCTCCAGTCCTA 1195 1134 AAGCGA--CATATGCTGATTCTCCTTTTCCAGGCTTGACCTCCTCCGCTCTCCAGTCGTA 1191

1196 CGTTAAATTGATCACCAAAGAGACCAAAGACTTCTTCTCCAAGGACAATCCAAGCAAGAA 1255 1192 CGTCAAACTGATCACGAAAGAGACCAAGGACTTTTTCTCCAAGAACAATCCAAGCAAGAA 1251 


\section{Continuação alinhamento}

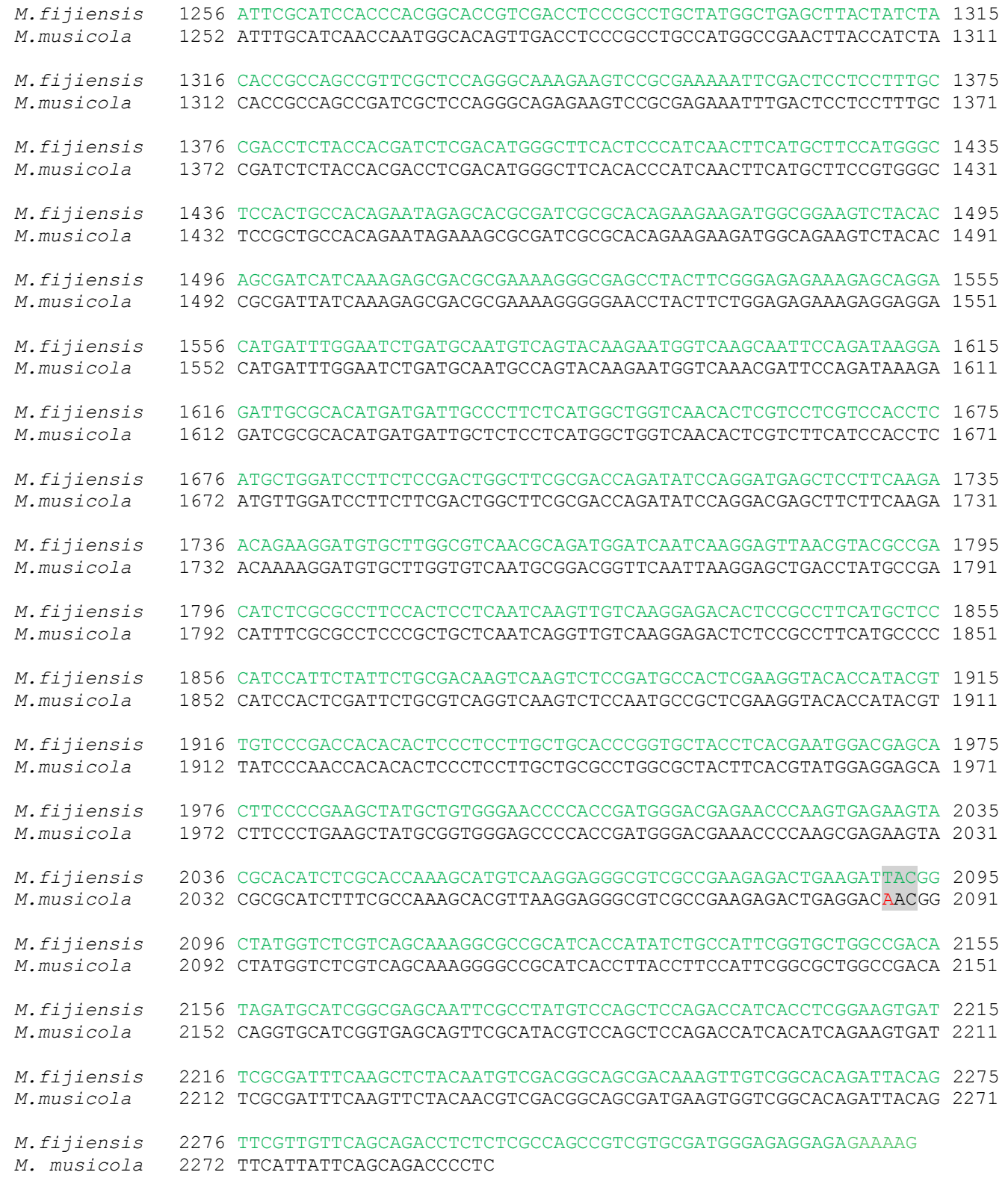

Figura 23. Alinhamentos entre nucleotídeos de CYP51 do isolado número 2 de Mycosphaerella musicola de São João da Aliança e de M. fijiensis (http://genome.jgipsf.org/Mycfi2/Mycfi2.home.html). Região promotora em laranja, região não codante em vermelho e codante em verde. Códon 461 de M. musicola marcado em cinza. 


\subsection{Discussão}

Os resultados para o bioensaio mostram que os isolados de $M$. musicola de São João da Aliança apresentaram tolerância a alguns fungicidas (tebuconazole, triadimenol e cyproconazole). Essa condição dos isolados pode estar relacionada à frequência aplicação dos fungicidas na área, de dois em dois meses. Na Fazenda Santos e CPAC as aplicações ocorrem em menor frequência. Ao contrário do observado no presente trabalho, onde todos os isolados de M. musicola apresentaram baixa sensibilidade a propiconazole, fungicida amplamente utilizado no controle das Sigatokas, diferentes graus de sensibilidade ao fungicida de isolados de M. fijiensis da Colômbia e Costa Rica já foram relatados (Romero \& Sutton, 1996; Guzmán, 2002; Canãs-Gutiérrez et al., 2009). Para M. graminicola, vários níveis de resistência já foram reportados para todos os azole registrados para o controle do patógeno (Leroux \& Walker, 2011; Cools \& Fraaije, 2013).

Comparando os isolados, foi possível observar uma correlação entre o grau de resistência e a presença de mutação. O sequenciamento de parte do gene CYP51 mostrou uma alteração na sequência de aminoácido do códon 461, que consequentemente resultou na alteração do aminoácido metionina para leucina. Essa mutação foi identificada em todos os isolados de São João da Aliança considerados tolerantes e não nos sensíveis. O alto grau de polimorfismo no gene CYP51 tem sido relatado para $M$. fijiensis e $M$. graminicola. A alteração identificada para os isolados de M. musicola é equivalente à mutação nos aminoácidos de Y459 em M. graminicola e de Y461D em M. fijiensis (Canãs-Gutiérrez et al., 2009). Para esse último, CanãsGutiérrez e colaboradores (2009) relataram substituições nos aminoácidos de Y461D juntamente com outras mutações (ex.: Y136F, A138G, A313G e Y463H/S/N/D) e as correlacionaram com a redução da sensibilidade ao fungicida propiconazole. Para isolados resistentes a propiconazole, os autores registraram a presença de mais de um SNP. Para os fungicidas azole, uma única mutação parece não ser suficiente para causar resistência dos patógenos, sendo necessário o acúmulo de algumas para provocar insensibilidade (Cools et al., 2013). Apesar desse acúmulo de mutações 
auxiliar na adaptação ao fungicida, ele também pode provocar desvantagens no fitness do patógeno e impedir a evolução desse genótipo (Canãs-Gutiérrez et al., 2009)

Segundo Cools e colaboradores (2010), alterações dos resíduos 459, semelhante ao encontrado em M. musicola, e 461 de MgCYP51 ocorrem frequentemente e são responsáveis pela redução da sensibilidade da proteína CYP51 a diferentes DMIs. Uma modelagem molecular da resistência a DMI em $M$. graminicola, realizada por Mullins e outros (2011) revelou que esses aminoácidos são importantes na ligação de DMI. Foi o primeiro modelo de CYP51 fúngico que fornece evidências sobre a importância de Y459-Y461 para a ligação desses fungicidas. De acordo com Canãs-Gutiérrez e colaboradores (2009), em M. fijiensis, o resíduo Y461D está localizado em uma região (laço antes da hélice L) da estrutura da proteína CYP51, que corresponde a região de sítios de ligação de fungicidas.

Chong e colaboradores (2011) sequenciaram o gene CYP51 de 40 isolados de M. fijiensis da África, América do Sul e sudeste da Ásia e encontraram várias mutações em isolados resistentes e sensíveis e correlacionaram essas alterações à resistência cruzada aos fungicidas propiconazole e cyproconazole. De acordo com esses autores, a presença de polimorfismos em isolados sensíveis pode ser resultado da variabilidade genética natural nesses locos que provavelmente não contribui para o desenvolvimento de resistência. Para Morin e outros (2004), mutações observadas, como SNP são amplamente distribuídas no genoma de muitas espécies em regiões codantes e não codantes.

Por apresentar um padrão de sensibilidade cruzada, não foi possível correlacionar a mutação observada com a tolerância a um fungicida específico do grupo DMI, embora um SNP possa conferir sensibilidade a mais de um fungicida. Para otimização dos resultados, seria necessário caracterizar o impacto da mutação observada, na sensibilidade de fungicidas DMI em população de M. musicola e avaliar se a substituição identificada é a responsável pela tolerância aos fungicidas observados. Embora o impacto de novas variantes de patógenos, como M. musicola sejam ainda desconhecidas, acredita-se que a sensibilidade aos fungicidas 
constantemente empregados, como os DMIs, seja amplamente afetada (Cools et al., 2011).

De acordo com Canãs-Gutiérrez e colaboradores (2009), devido a alta taxa de conservação da estrutura da proteína CYP51 em M. fijiensis e M. graminicola, é possível que mutações encontradas na proteína de $M$. graminicola tenham efeitos similares à resistência a DMIs em M. fijiensis. É possível que essa afirmativa se estenda a $M$. musicola uma vez que o alinhamento da sua sequência com a de $M$. fijiensis exibiu um alto grau de conservação do gene CYP51. Apesar de um único ponto de mutação ter sido observado na sequência completa de CYP51 do indivíduo número dois de São João da Aliança, mais alterações podem ser identificadas em outros isolados.

O evento de mutação observado no trabalho é parte do processo microevolutivo que juntamente com recombinação sexual leva ao aparecimento de isolados mais tolerantes a determinados grupos de fungicidas. Esses processos de adaptação podem ser afetados pelo intenso uso de fungicidas, que causam pressão seletiva na população do patógeno e favorece a seleção e disseminação de novos alelos potencialmente resistentes e com maior capacidade competitiva em ambientes desfavoráveis (Chong et al., 2011; Cools et al., 2011).

\subsection{Conclusão}

Aproximadamente $10 \%$ dos isolados analisados apresentaram tolerância aos fungicidas DMIs analisados e os demais $90 \%$ dos isolados de $M$. musicola mostraram sensibilidade. Os resultados obtidos indicam que, assim como outras espécies do gênero Mycosphaerella, M. musicola mostra variabilidade quanto à sensibilidade a fungicidas DMIs e que houve correlação entre a sensibilidade e a presença de uma mutação pontual (SNP). Esta é a primeira investigação no gene CYP51 em isolados de M. musicola e, com base nos resultados coletados, uma investigação mais abrangente deve ser realizada em mais indivíduos de outras populações do patógeno. Isso poderá 
fornecer informações para a compreensão da estrutura genética e mecanismos de resistência de $M$. musicola e ajudará na otimização do controle de Sigatoka-amarela pelo uso fungicidas DMIs. 


\section{Capítulo 4. Caracterização do efetor LysM na espécie modelo Mycosphaerella graminicola}

\section{Resumo}

Mycosphaerella graminicola é o agente causador de Septoriose em trigo (Triticum spp.), uma das principais doenças foliares no cereal em países da Europa. Durante a colonização de folhas de trigo, o patógeno exibe um longo período latente, anterior ao desenvolvimento dos sintomas na hospedeira. Proteínas efetoras LysM, tem sido implicadas na captura de fragmentos de quitina liberados da parede celular do fungo durante a infecção, retardando a resposta de defesa da planta. Até o momento, a linhagem IPO323 de M. graminicola é o modelo para estudos da patogênese do fungo, incluindo as análises sobre a influência do LysM durante a fase assintomática do patógeno. Entretanto, IPO323 não expressa a proteína verde fluorescente (GFP) como a linhagem B3-GFP, que pode permite a detecção in situ de importantes fatores da patogênese de M. graminicola durante os estágios de infecção do fungo, assim como investigar a influência do efetor 3LysM durante a colonização do patógeno. $\mathrm{O}$ presente estudo teve como objetivos caracterizar cultivares de trigo suscetíveis para a linhagem B3-GFP para verificar a influência da proteína na virulência do patógeno; acompanhar a colonização de B3-GFP em folhas de trigo, via confocal de varredura a laser (CLSM) e gerar uma linhagem B3-GFP mutante não funcional para o gene 3LysM (B3-GFP $\Delta$ 3LysM). Dezoito genótipos de trigo resistentes e suscetíveis, e um de cevada foram inoculados com as linhagem B3-GFP e ST16 (tipo selvagem) de $M$. graminicola. Não foram registrados diferenças entre o desenvolvimento dos sintomas provocados pelas linhagens, permitindo predizer que GFP não influência na colonização do patógeno. Na análise por CLSM, foi confirmado que GFP é expressa durante todo o ciclo de infecção e colonização do patógeno em folhas de trigo suscetíveis. Para a obtenção da linhagem B3-GFP $\Delta 3$ LysM, B3-GFP foi transformado via Agrobacterium tumefaciens. O DNA homólogo de 3LysM não foi integrado ao 
sítio alvo, sendo necessário novos experimentos para a obtenção da linhagem esperada. As análises realizadas contribuem com as investigações sobre a influência do gene LysM na colonização de $M$. graminicola e poderá fornecer informações para estudos futuros acerca dos efetores em outros patossistemas, principalmente de espécies biologicamente relacionadas, como M. musicola.

\subsection{Introdução}

Septoriose é uma das principais doenças com importância global nos cultivos de cereais (Eyal, 1999) e atualmente é a doença foliar do trigo (Triticum sp.) de maior relevância na Europa, incluindo o Reino Unido e muitas outras partes temperadas no mundo. Provocada por Mycosphaerella graminicola (Fuckel) Schröter (Zymoseptoria tritici) (anamorfo: Septoria tritici), manchas de S. tritici podem reduzir as colheitas de trigo em 30 a 50\%, provocando um grande impacto econômico (Eyal et al., 1987).

M. graminicola é de difícil controle uma vez que as populações apresentam elevado nível de variabilidade genética (Linde et al., 2002) e mostram uma incomum biologia para um patógeno. Ao contrário da maioria dos fitopatógenos, $M$. graminicola infecta o tecido foliar através dos estômatos e exibe um longo período latente antes do desenvolvimento dos sintomas (Keon et al., 2007; Dean et al., 2012). Tal fato caracteriza o patógeno como hemibiotrófico, assim como Mycosphaerella musicola, uma vez que este parece gastar parte significante do seu ciclo de infecção alimentando-se como biotrófico, antes de uma repentina mudança para necrotrófico levando o tecido da hospedeira ao colapso (Luttrell, 1974; Keon et al., 2007; Dean et al., 2012).

Durante a interação de alguns fungos fitopatogênicos com seus hospedeiros, como Cladosporium fulvum em folhas de tomate (Solanum lycopersicum), a quitina, classificada como padrões moleculares associados ao patógeno (PAMPs - pathogenassociated molecular patterns) (Jones \& Dangl, 2006), liberada durante a ação enzimática, é capaz de desencadear a primeira linha de defesa da planta, denominada imunidade desencadeada por PAMPs (PTI - PAMP-triggered immunity) (Bolton et 
al., 2008; Boller \& He, 2009; de Jonge et al., 2010; Marshall et al., 2011). Os patógenos, por sua vez, possuem a capacidade de suprimir o PTI, lançando de efetores especializados, durante uma fase específica da interação com a planta hospedeira.

Proteínas efetoras extracelulares, tais como a Ecp6, que foi descrita e bem caracterizada em C. fulvum em folhas de tomate e se mostrado necessárias para a virulência completa (Bolton et al., 2008; de Jonge et al., 2010). Até o momento, é a única proteína efetora de $C$. fulvum com ortólogos em outras espécies fúngicas como M. musicola (Passos et al., 2013) e M. graminicola (Marshall et al., 2011). Ecp6 possui três domínios LysM que, em geral, estão implicados na ligação de carboidratos, incluindo na captura de fragmentos de quitina que são liberados da parede celular do fungo durante a infecção, evitando a ativação por PAMPs e elicitação da resposta de defesa da planta (Bolton et al., 2008; de Jonge et al., 2010, Akcapinar et al., 2015).

Para M. musicola, Passos e colaboradores (2013) analisaram o transcritoma da folha de Musa acuminata durante a interação in vivo com o patógeno, e identificaram homólogos da proteína efetora Ecp6 entre os transcritos do patógeno. Apesar da identificação dos genes efetores candidatos, sua função ainda precisa ser confirmada experimentalmente por superexpressão, interrupção ou silenciamento gênico em isolados fúngicos, e subsequente análise da (a)virulência em plantas hospedeiras (Stergiopoulos \& Wit, 2009).

Ao analisar homólogos de Ecp6 de C. fulvum na linhagem IPO323 de $M$. graminicola, dois (Mg3LysM, Mg1LysM) de três genes efetores foram altamente expressos, traduzindo proteínas especialmente durante a fase assintomática de infecção no trigo (até sete dias após a inoculação) (Marshall et al., 2011). Na fase de necrose da folha, as expressões dos genes foram baixas indicando um controle temporal da expressão de efetores de virulência LysM durante a patogênese na planta. Atualmente, o grupo investiga quais fatores (planta específica ou outros sinais químicos) controlam a expressão de efetores MgLysM, bem como a influência do efetor 3LysM na colonização do patógeno. 
A identificação e análise molecular e funcional de genes efetores enriquece a compreensão sobre a virulência do patógeno e o sistema de defesa da planta, assim como contribui para elucidar os mecanismos envolvidos na interação patógeno $\mathrm{x}$ planta, fator fundamental para o desenvolvimento de novas estratégias de controle de doenças de plantas. Estudos com a linhagem IPO323 de M. graminicola já demostraram que a linhagem é um valioso modelo para a investigação da interação desse patógeno fúngico com trigo (Zwiers et al., 2003; Marshall et al., 2011). Entretanto, apesar de ser a mais bem caracterizada linhagem da espécie, IPO323 não expressa a proteína verde fluorescente - GFP (green fluorescent protein) intensamente como a linhagem B3-GFP de M. graminicola. O uso de estirpes transformadas expressando GFP, como B3-GFP, pode permitir a detecção in situ de importantes fatores da patogênese de $M$. graminicola durante os estágios de infecção do fungo, assim como investigar a influência do efetor 3LysM durante a colonização do patógeno. Logo, a obtenção de uma linhagem B3-GFP mutante com 3LysM não funcional possibilitará elucidar questões como o momento e o local na hospedeira onde o efetor é fundamental para a colonização do patógeno.

Portanto, como parte de um projeto maior que visa investigar a influência do gene 3 LysM durante a interação da linhagem B3-GFP de $M$. graminicola com trigo, o presente estudo teve como objetivos: caracterizar cultivares de trigo suscetíveis a isolados B3-GFP para verificar a influência de GFP na virulência do patógeno; acompanhar a colonização de B3-GFP em folhas de trigo, via microscopia de varredura, e gerar uma linhagem B3-GFP mutante não funcional para o gene $3 L y s M$.

\subsection{Material e Métodos}

\subsubsection{Amostras fúngicas e variedades de trigo}

Os experimentos foram realizados nos laboratórios do Instituto de Pesquisa Rothamsted Research - Harpenden, Inglaterra. Os isolados de M. graminicola: ST16 (tipo selvagem) e B3-GFP (linhagem transformada com a proteína verde fluorescente) 
foram utilizados como inóculos, após serem recuperados de preservação a $-80^{\circ} \mathrm{C}$ em glicerol 50\% (vol/vol) e plaqueados em meio de cultura YPD (Yeast Peptone Dextrose) por 5 dias a $15^{\circ} \mathrm{C}$. Como hospedeiros, foram utilizados 18 genótipos de trigo resistentes e suscetíveis (cultivares Arina, Balance, Bulgaria, Courtot, Estanznilla, Isreal, Kavkaz, Obelisk, Raffles, Salmouni, Sullivan, Synthetic 6x, Synthetic H3, Tadinia, Taichung, Tonic, TE 9111, Veranopolis), e um genótipo de cevada (Hordeum vulgare) não-hospedeira (Atlas).

\subsubsection{Resposta de cultivares de trigo ao modelo B3-GFP}

Para verificar a suscetibilidade de cultivares de trigo ao isolado B3 - GFP, um bioensaio foi utilizado, como descrito por Keon et al. (2007). Em torno de 15 sementes de cada cultivar foram distribuídas ao longo do maior lado de bandejas (15 $\mathrm{cm} \times 20 \mathrm{~cm}$ x $5 \mathrm{~cm}$ ), acrescidas de terra adubada numa profundidade de aproximadamente $2 \mathrm{~cm}$. As bandejas com as mudas foram armazenadas em casa de vegetação, com UR (umidade relativa) de $88 \%$ e temperatura de $16^{\circ} \mathrm{C}$. Após 21 dias de crescimento, a segunda folha de cada muda das cultivares foi fixada em um suporte metálico, com a face adaxial para cima, usando fita dupla face. Para cada cultivar, seis folhas foram selecionadas, três para cada estirpe: ST16 (controle) e B3-GFP. As folhas foram inoculadas com esporos fúngicos, preparados a partir de culturas de ST16 e B3-GFP cultivadas em placas com meio de cultura YPD por 7 dias a $15^{\circ} \mathrm{C}$, na densidade de $3,5 \times 10^{6}$ esporos por mililitros em água contendo $0,1 \%$ (vol/vol) Tween 20. A inoculação foi realizada com o auxílio de um cotonete, para distribuir a suspensão sobre a superfície das folhas. Após uma incubação inicial por 72 horas, a $100 \%$ de UR, as plantas inoculadas foram incubadas a $16^{\circ} \mathrm{C}$ com 16 horas de período de luz a 88\% de UR por 21 dias (Figura 24). Passado esse período, tempo necessário para a visualização de sintomas típicos da doença, registros fotográficos foram feitos para análise dos resultados. 

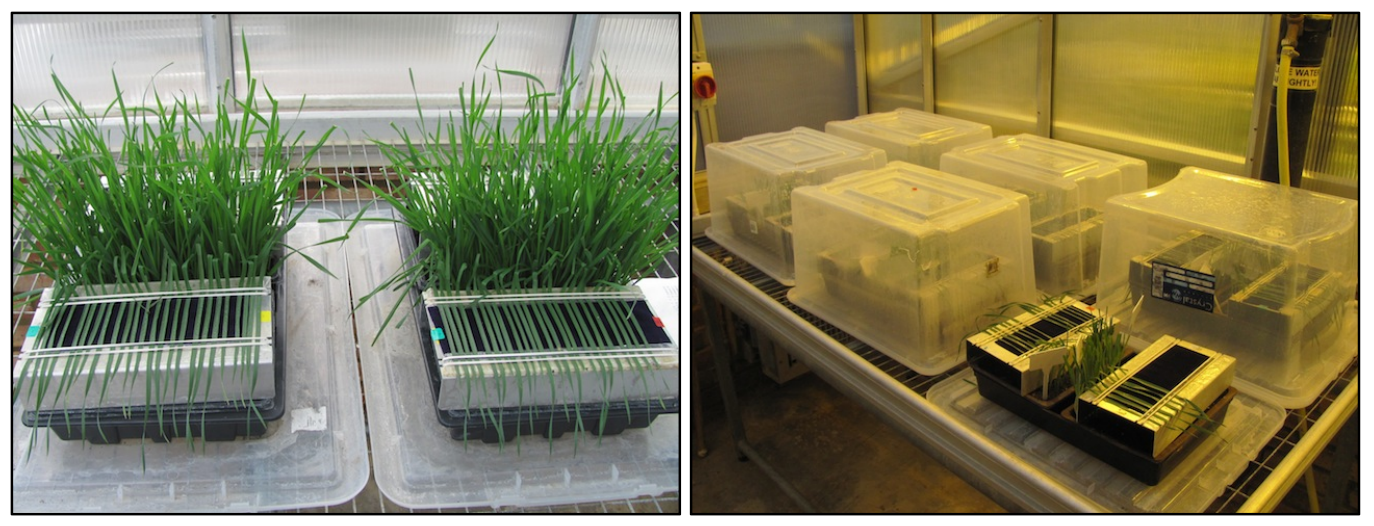

Figura 24. Variedades de trigo preparadas para inoculação das estirpes de Mycosphaerella graminicola ST16 e B3-GFP.

\subsubsection{Colonização de M. graminicola em trigo}

Para avaliar a colonização de B3-GFP em folhas de trigo, foi elaborado um novo bioensaio (Keon et al., 2007), com duas variedades de trigo: resistente (Tonic) e suscetível (Taichung); e uma não hospedeira (cevada). O preparo das mudas das cultivares, a inoculação do patógeno e a incubação das plantas seguiram os mesmos procedimentos descritos para o bioensaio anterior. No $21^{\circ}$ dia de crescimento, a segunda folha de 15 mudas de cada cultivar foi selecionada e inoculada com esporos fúngicos, preparados a partir de cultura de B3-GFP cultivada em placa com meio de cultura YPD por 7 dias a $15^{\circ} \mathrm{C}$, na densidade de $3,5 \times 10^{6}$ esporos por mililitros em água contendo $0,1 \%$ (vol/vol) Tween 20 . As observações da colonização do patógeno nas folhas das cultivares foram realizadas $1,4,10,14$ e 21 dias após a inoculação com o auxílio de microscópio confocal de varredura a laser (CLSM) e microscópio estereoscópio. Para cada dia de observação, uma folha de cada cultivar resistente, suscetível e não hospedeira inoculadas com a linhagem de M. graminicola foi removida com o auxílio de uma lâmina, colocada em falcon $(15 \mathrm{~mL})$ para o isolamento de material transformado e conduzida da casa de vegetação ao laboratório 
de bioimagem. Fragmentos de cada folha, de aproximadamente $1 \mathrm{~cm}^{2}$ foram fixadas em lâminas com auxílio de fita adesiva transparente para observação ao microscópio e aquisição de imagens.

\subsubsection{Sequenciamento da região 3LysM de B3-GFP}

Para a identificação da região 3LysM de B3-GFP, a mesma região na linhagem IPO323 de M. graminicola (http://genome.jgipsf.org/Mycgr3/Mycgr3.home.html) (Figura 25) foi utilizada como referência para o desenho de primers (Programa Primer3), uma vez que B3-GFP ainda não possui seu genoma sequenciado. Três pares de primers foram gerados (Tabela 11), com o intuito de cobrir todo o gene 3 LysM de B3-GFP (Figura 26). As PCR $(20 \mu \mathrm{L})$, foram preparadas em tubos Eppendorf de 0,2 $\mu \mathrm{L}$, contendo $20 \mathrm{ng}$ de DNA, $10 \mu \mathrm{L}$ de ready Mix - Red Taq ${ }^{\circledR} \mathrm{PCR}$, reação Mix com $\mathrm{MgCl}_{2}$ (Sigma) e $0,25 \mu \mathrm{M}$ de cada primer. Os tubos foram acondicionados em termociclador (Esco Swfit MaxPro) e as reações conduzidas nas seguintes condições: 1 ciclo para etapa inicial de desnaturação $\left(94^{\circ} \mathrm{C}\right.$ por 5 minutos), seguido de 30 ciclos com uma etapa de desnaturação $\left(94^{\circ} \mathrm{C}\right.$, por 30 segundos), uma de anelamento $\left(56^{\circ} \mathrm{C}\right.$ por 30 segundos) e uma de extensão $\left(72^{\circ} \mathrm{C}\right.$ por 1 minutos). Os fragmentos obtidos foram clonados em vetor pGEN-T easy. Clones individuais foram sequenciados (Sanger) em ambos sentidos usando primers T7 e SP6 (MWG Biotech) e alinhados (Blastn, Blastp, Clustalw2) com outras linhagens de $M$. graminicola obtidas em Marshall et al. (2011). 


\section{Cromossomas}



Figura 25. Mapa cromossômico de Mycosphaerella graminicola IPO323, mostrando a localização de 3LysM no cromossomo 11 (estExt_fgenesh1_pg.C_chr_110126). Os números de 1 a 21 correspondem aos cromossomas do patógeno. 
Tabela 11: Sequências de primers utilizados para o gene $3 L y s M$

\begin{tabular}{llc}
\hline \multicolumn{1}{c}{ Primers } & \multicolumn{1}{c}{ Sequências } & $\begin{array}{c}\text { Tamanho } \\
\text { (pb) }\end{array}$ \\
\hline 3LysM Left & $\begin{array}{l}\text { F: CTCGAGAACGCCGATGATGA } \\
\text { R: ACGGCATCGATAACCCAGAC }\end{array}$ & 992 \\
3LysM Mid & $\begin{array}{l}\text { F: ATGTTGAACGAGGTGGCGAT } \\
\text { R: AATTCGTGCGAACAGGTTGC }\end{array}$ & 1.285 \\
3LysM Right & F: TGGGATATTGCAGGCTTCGG & 1.268 \\
& R: GGCAGTCTGTTGACCGTACA & \\
FL1 & F: TATTGGGCGCGGTGTATTAT & 1.579 \\
FL2 & R: ACAAAACCCTCCAACCTCCT & \\
& F: ATGGGAACGAATGTGATGGT & 1.080 \\
FL1 end & R: CGAAGTTGATGCCTGACAGA & \\
FL2st & F: GGTGCCTGGAGCTGTTAGAG & 2.016 \\
FL1 & R: GCGAGCCTACTCATGGATTC & \\
GENin & F: TGATGCGACAGATGGAAGAG & 461 \\
\hline
\end{tabular}

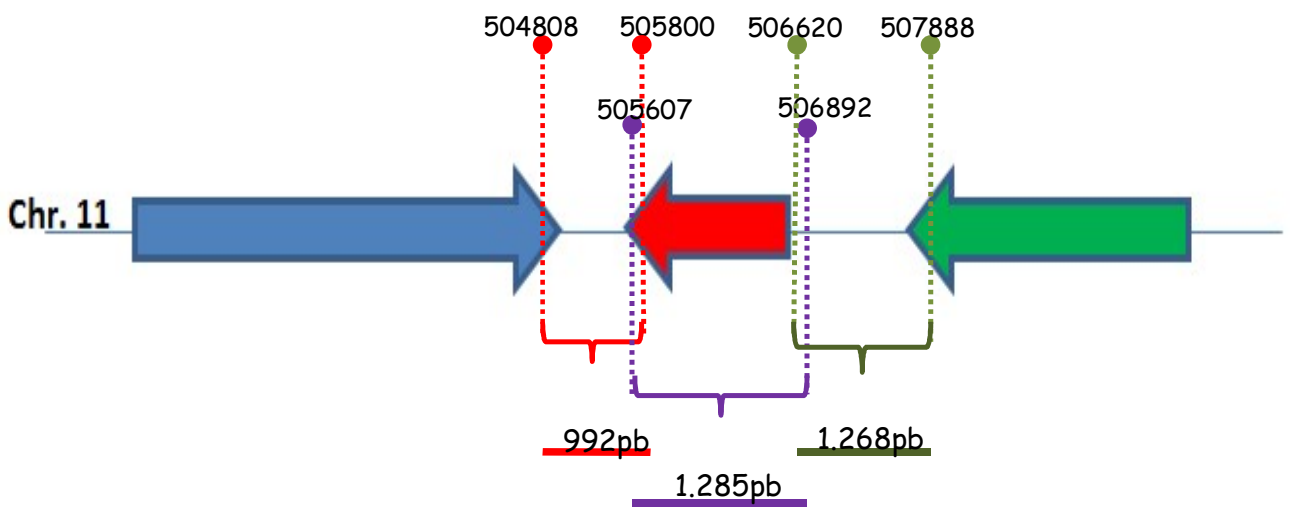

Figura 26. Esquema representando o gene $3 L y s M$ de Mycosphaerella graminicola IPO323 (seta vermelha), dois genes vizinhos (setas azul e verde) e a região de pareamento dos primers para amplificação do gene $3 L y s M$ de B3-GFP. 


\subsection{5 - Síntese de B3-GFP mutante não funcional para o gene 3LysM}

\section{a - Clonagem dos fragmentos em Escherichia coli}

Confirmada a identidade dos fragmentos como sendo o gene $3 L y s M$ de B3GFP, deu-se início à construção de 3LysM nocaute. Para iniciar a construção do plasmídeo, novos primers para a região do gene 3LysM de B3-GFP foram desenhados (programa Primer3), com base em IPO323 de M. graminicola (http://genome.jgipsf.org/Mycgr3/Mycgr3.home.html), excluindo a região do peptídeo sinal (Figura 27). O primeiro fragmento de $1.579 \mathrm{pb}$ foi amplificado utilizando os primers FL1F / FL1R com sítios de restrição ApaI-EcoRI. O segundo fragmento de $1.080 \mathrm{pb}$ foi amplificado com os primers FL2F / FL2R, com sítios de restrição BamHI-XbaI (Tabela 11). Ambos fragmentos foram gerados em PCR preparadas em Eppendorf de $0,2 \mu \mathrm{L}$, para um volume final de $20 \mu \mathrm{L}$, contendo 20 ng de DNA, $10 \mu \mathrm{L}$ de Mix - Red Taq ${ }^{\circledR} \mathrm{PCR}$, com $\mathrm{MgCl}_{2}$ (Sigma), 0,25 $\mu \mathrm{M}$ de cada primer. Os tubos foram acondicionados em termociclador (Petier Thermal Cycler - 200) e as reações conduzidas nas seguintes condições: 1 ciclo para etapa inicial de desnaturação $\left(94^{\circ} \mathrm{C}\right.$ por 5 minutos), seguido de 30 ciclos com uma etapa de desnaturação $\left(94^{\circ} \mathrm{C}\right.$, por 30 segundos), uma de anelamento $\left(50^{\circ} \mathrm{C}\right.$ por 30 segundos $)$ e uma de extensão $\left(72^{\circ} \mathrm{C}\right.$ por 1 minuto e 30 segundos). Os fragmentos foram preparados para serem inseridos no vetor pCGEN, contendo gene de resistência geneticina (G418) (Figura 28). Para isso, ambos passaram por reações de digestões preparadas para um volume final de $20 \mu \mathrm{L}$. Para o inserto FL1, foram utilizados $16 \mu \mathrm{L}$ de DNA (38 ng/ $\mu \mathrm{L}), 2 \mu \mathrm{L}$ de tampão multi core (10X), $1 \mu \mathrm{L}$ de cada enzima de restrição: ApaI e EcoRI. Para a digestão do vetor foram utilizados $10 \mu \mathrm{L}$ do plasmídeo (95 ng/ $\mu \mathrm{L}), 2 \mu \mathrm{L}$ de tampão multi core (10X), 1 $\mu \mathrm{L}$ de cada enzima de restrição: ApaI e EcoRI e $6 \mu \mathrm{L}$ de água. As reações foram incubadas a $37^{\circ} \mathrm{C}$ por 2 horas e em seguida, visualizadas em gel de agarose $(0,8 \%)$, corrido por 1,5 horas a $60 \mathrm{~V}$. As bandas referentes ao inserto e vetor foram eluídas e purificadas de acordo com o protocolo do kit (50) - QIAquick. A reação de ligação 
entre o inserto FL1 e o vetor pCGEN foi preparada em seguida para um volume final de $20 \mu \mathrm{L}$, utilizando $4 \mu \mathrm{L}$ de tampão de ligação T4, $10 \mu \mathrm{L}$ do inserto $(10 \mathrm{ng} / \mu \mathrm{L}), 5 \mu \mathrm{L}$ do vetor $(16 \mathrm{ng} / \mu \mathrm{L})$ e $1 \mu \mathrm{L}$ de ligase T4. A reação foi armazenada durante a noite (o/n) a $4^{\circ} \mathrm{C}$ e o produto final foi clonado em Escherichia coli via eletroporação. Para essa etapa, a reação foi precipitada em 2 volumes de etanol mais $1 \mu \mathrm{L}$ de acetato (3$8 \mathrm{M})$ por 2 horas a $-20^{\circ} \mathrm{C}$. Em seguida, centrifugada por 2 minutos a $4000 \mathrm{rpm}$ e o pelete resultante lavado duas vezes com etanol $70 \%$. Todo o sobrenadante foi removido e o tubo deixado para secar durante 2-3 minutos. O pelete foi ressuspenso em $10 \mu \mathrm{L}$ de água e colocado em gelo.

A eletroporação, foi conduzida com $20 \mu \mathrm{L}$ de células competente de E. coli e com $2 \mu \mathrm{L}$ da reação de ligação em cuveta. Após passar pelo eletroporador, $1 \mathrm{~mL}$ de meio SOC (Super Optimal broth with Catabolite repression) foi acrescido à reação, que então foi transferida para tubos Falcon de $15 \mathrm{~mL}$ e armazenada por 1 hora a $37^{\circ} \mathrm{C}$ em agitador (câmara incubadora com agitação orbital) e, então, plaqueada em meio LB (Luria-Bertani) mais canamicina e armazenada o/n a $37^{\circ} \mathrm{C}$. As colônias de E. coli que surgiram no meio de cultura foram selecionadas e transferidas para meio líquido LB e armazenadas no agitador o/n a $37^{\circ} \mathrm{C}$. Para a remoção do plasmídeo das células de E. coli um miniprep foi realizado, de acordo com o protocolo do Miniprep Kit 250. O vetor gerado, "pCGENLysFL1" foi utilizado para a clonagem do segundo fragmento em E. coli. Neste caso, vetor e inserto passaram por reações de digestões preparadas para um volume final de $20 \mu \mathrm{L}$. Para o inserto, foram utilizados $12 \mu \mathrm{L}$ de DNA (60 ng/ $\mu \mathrm{L}), 2 \mu \mathrm{L}$ de tampão $\mathrm{E}(10 \mathrm{X}), 1 \mu \mathrm{L}$ de cada enzima de restrição: $X b a \mathrm{I}$ e $B a m \mathrm{HI}$ e $4 \mu \mathrm{L}$ de água. Para a digestão do vetor foram utilizados $10 \mu \mathrm{L}$ do plasmídeo $(12 \mathrm{ng} / \mu \mathrm{L}), 2 \mu \mathrm{L}$ de tampão multi core $(10 \mathrm{X}), 1 \mu \mathrm{L}$ de cada enzima de restrição: $X b a \mathrm{I}$ e BamHI e $6 \mu \mathrm{L}$ de água. Os demais procedimentos seguiram a mesma metodologia utilizada para a clonagem do primeiro fragmento. A confirmação do plasmídeo final (pCGENA3LysM) foi feita pela análise de restrição. Em seguida, o vetor foi introduzido em Agrobacterium tumefaciens (AgI-1) e subsequentemente usado para a transformação de M. graminicola. 


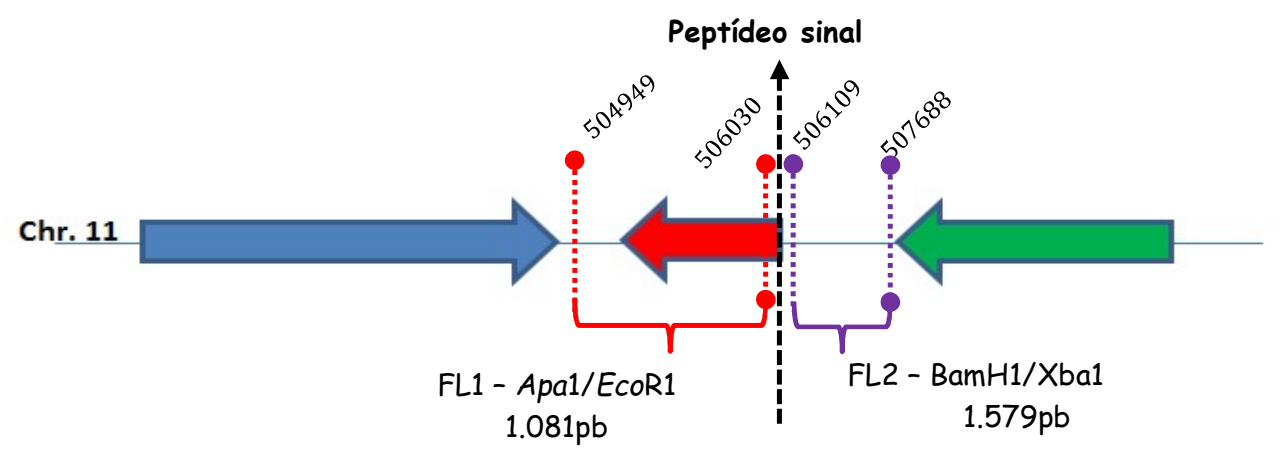

Figura 27. Esquema representando a região de pareamento dos primers para amplificação do gene $3 L y s M$ de B3-GFP, sem peptídeo sinal. 

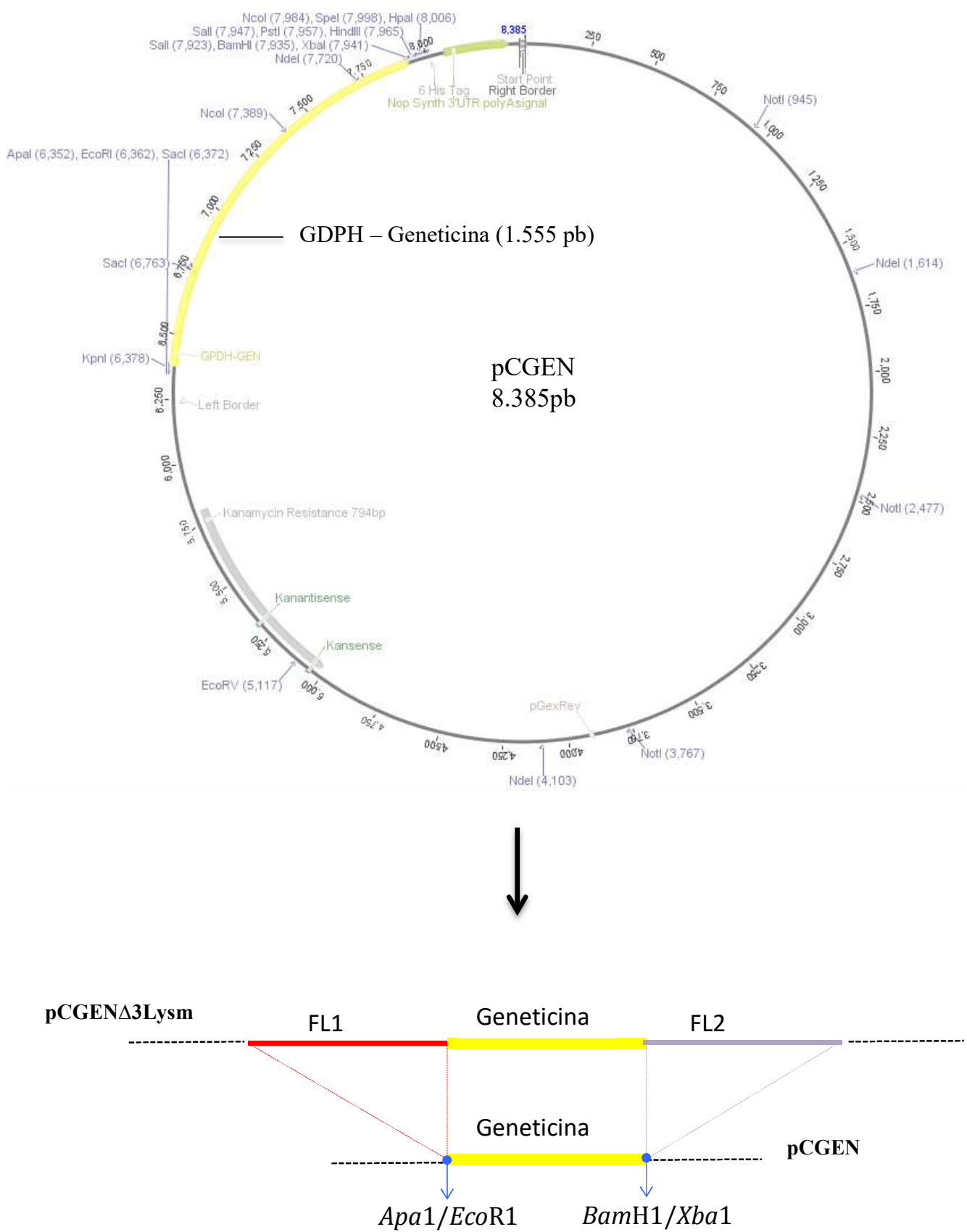

Figura 28. Esquema apresentando o plasmídeo pCGEN e os locais de ação das endonucleases no vetor; e a geração do vetor pCGEN $\Delta$ 3LysM exibindo os insertos FL1 e FL2. 


\section{b - Transformação de Agrobacterium tumefaciens}

A transformação de A. tumefaciens (AgI-1), com o vetor pCGEN $\Delta 3$ LysM contendo os dois insertos (FL1 e FL2), foi realizada através do método de congelamento-descongelamento (An et al., 1988). Inicialmente, células competentes de A. tumefaciens foram preparadas. Para tanto, $2 \mathrm{~mL}$ da colônia bacteriana, previamente crescida $\mathrm{o} / \mathrm{n}$ em $5 \mathrm{~mL}$ de meio $\mathrm{LB}$ a $28^{\circ} \mathrm{C}$, foram adicionadas a $50 \mathrm{~mL}$ de meio LB em Elernmeyer de $250 \mathrm{~mL}$ e misturado vigorosamente a $28^{\circ} \mathrm{C}$ até o crescimento colonial de 0,5 a 1,0 de $\mathrm{OD}_{600}$ (densidade óptica). Posteriormente, a suspensão de células foram centrifugadas a $5.000 \mathrm{rpm}$ a $4{ }^{\circ} \mathrm{C}$ por 5 minutos. $\mathrm{O}$ sobrenadante foi descartado e as células resuspensas em $1 \mathrm{~mL}$ de solução gelada de $\mathrm{CaCl}_{2}(20 \mathrm{mM})$. Alíquotas de $0.1 \mathrm{~mL}$ das células foram redistribuídas em tubos eppendorfs $(1,5 \mathrm{~mL})$ e armazenadas a $-80^{\circ} \mathrm{C}$. A transformação iniciou-se com a adição de $1 \mu \mathrm{g}$ do DNA plasmidial pCGEN $\Delta 3 \mathrm{Lysm}$ a $100 \mu \mathrm{L}$ de células competentes de $A$. tumefaciens e incubado em banho-maria a $37^{\circ} \mathrm{C}$ por 5 minutos. Em seguida, $1 \mathrm{~mL}$ de meio LB foi acrescentado ao tubo, transferido para falcon de $15 \mathrm{~mL}$ e incubado em agitador a $28^{\circ} \mathrm{C}$ por 3 horas. As células foram plaqueadas em meio LB com canamicina $(50 \mu \mathrm{L} / \mathrm{mL})$ e incubadas a $28^{\circ} \mathrm{C}$ por 3 dias. A integridade do vetor na $A$. tumefaciens foi confirmada via PCR com os primers FL1F e FL2R.

\section{c - Transformação de $M$. graminicola mediada por $A$. tumefaciens}

A. tumefaciens (AgI-1) contendo pCGEN $\triangle 3$ LysM foi usado para a geração da linhagem B3-GFP mutante não funcional para o gene 3LysM (B3 $\Delta 3$ LysM). A transformação foi realizada como descrito por Zwiers \& Waard (2001) com algumas modificações. Esporos de M. graminicola apresentando crescimento tipo levedura foram suspensos em meio de indução (IM) e A. tumefaciens apresentando crescimento na fase exponencial (ou $\mathrm{OD}=0,25$ ) em IM foram utilizados na transformação. A suspensão fúngica e a cultura de $A$. tumefaciens foram misturadas em partes iguais (100 $\mu \mathrm{L}$ cada) a $1 \mu \mathrm{L}$ de acetoseringona (indutor de transferência de T-DNA) e 
plaqueados em membranas de celofane sobre placas com IM também contendo 200 $\mu \mathrm{M}$ de acetoseringone. Após 3 dias a $16^{\circ} \mathrm{C}$, as membranas de celofane foram transferidas para placas com meio mínimo de Aspergillus nidulans contendo geneticina e timentina a $100 \mu \mathrm{g} / \mathrm{mL}$ cada. Aproximadamente 7 dias após a incubação a $16^{\circ} \mathrm{C}$, as placas foram avaliadas para possíveis transformantes resistentes a geneticina. Colônias fúngicas de possíveis transformantes foram coletadas e plaqueadas em meio YPD contendo geneticina e timentina. Mais duas subculturas foram preparadas para a obtenção de material de uma única colônia fúngica com crescimento tipo levedura e para a eliminação de células de A. tumefaciens. A inserção do T-DNA foi confirmada por PCR do DNA genômico.

\section{d. Extração do DNA genômico fúngico}

O DNA genômico foi extraído de 5 a $10 \mathrm{mg}$ de micélio fúngico cultivado por 5 dias a $16^{\circ} \mathrm{C}$ em meio YPD, usando Fastprep FP120. Para tanto, tubos de $2 \mathrm{~mL}$ com o material fúngico de 40 possíveis transformantes, foram preenchidos com $700 \mu \mathrm{L}$ de tampão de extração: TEN (2X), SDS (2\%), $\mathrm{C}_{12} \mathrm{H}_{8} \mathrm{~N} . \mathrm{H}_{2} \mathrm{O}$ (SIGMA P-9375), PVP -40T e $\beta$-mercaptoetanol (1\%), homogeneizado em Fastprep por 45 segundos e incubados em banho maria a $65^{\circ} \mathrm{C}$ por 20 minutos. Posteriormente, $350 \mu \mathrm{L}$ de acetato de amônia $(7.5 \mathrm{M}) \mathrm{a}-20^{\circ} \mathrm{C}$ foram adicionados às amostras que então, foram incubadas em gelo

por 20 minutos. Posteriormente, as amostras foram centrifugadas por 15 minutos a $13.200 \mathrm{rpm}$ e o sobrenadante transferido para microtubos $(2 \mathrm{~mL})$ previamente acrescidos de $900 \mu \mathrm{L}$ de isopropanol $\left(-20^{\circ} \mathrm{C}\right)$. Após 15 minutos de incubação à temperatura ambiente, as amostras foram novamente centrifugadas por 15 minutos a $13.400 \mathrm{rpm}$ e o sobrenadante descartado. O pelete foi lavado 2 vezes com $400 \mu \mathrm{L}$ de álcool $70 \%$ e os tubos deixados para secar por 30 minutos. O DNA foi ressuspenso com $200 \mu \mathrm{L}$ de água destilada esterilizada e quantificado com espectrofotômetro NanoDrop 1000. Para confirmação da inserção do T-DNA, PCR foram conduzidas utilizando algumas combinações de primers: FL1outF / GENinR, FL1F / GENinR e FL1endF / FL2stR (Tabela 11; Figura 29). Os tubos de PCR foram acondicionados 
em termociclador (Petier Thermal Cycler - 200) e as reações conduzidas nas seguintes condições: 1 ciclo para etapa inicial de desnaturação $\left(94^{\circ} \mathrm{C}\right.$ por 5 minutos), seguido de 30 ciclos com uma etapa de desnaturação $\left(94^{\circ} \mathrm{C}\right.$, por 30 segundos), uma de anelamento $\left(57^{\circ} \mathrm{C}\right.$ por 1 minuto e 30 segundos) e uma de extensão $\left(72^{\circ} \mathrm{C}\right.$ por 3 minuto). As reações foram visualizadas em gel de agarose $(0,8 \%)$, corrido por 1,5 horas a $60 \mathrm{~V}$.

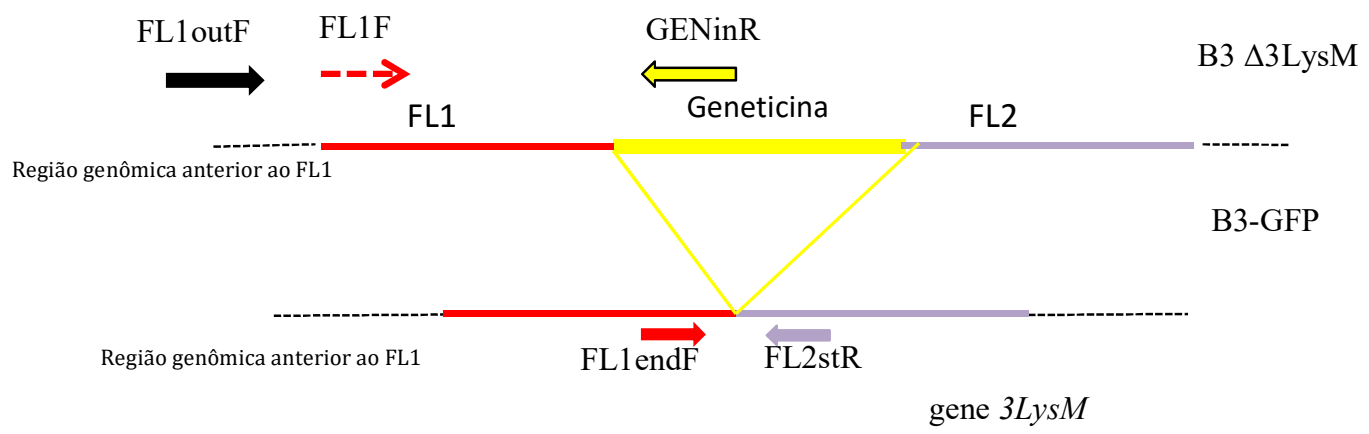

Figura 29. Esquema exibindo as regiões flanqueadas pelos primers (representados pelas setas) utilizados para a confirmação da inserção do T-DNA no DNA genômico de B3 $\Delta 3$ LysM.

\subsection{Resultados}

\subsubsection{Resposta de cultivares de trigo ao modelo B3-GFP}

De todas as cultivares de trigo analisadas, Arina, Balance, Kavkaz, Rafles, Sullivan, Synthetic 6x, Synthetic H3, Tonic, TE 9111 e a espécie não hospedeira (cevada) mostraram resistência a B3-GFP assim como à linhagem tipo selvagem ST16, não exibindo nenhum sinal de sintomas de septoriose. As demais cultivares, Bulgaria, Courtot, Estanzinilla, Israel, Obelisk, Salmouni, Tadinia, Taichung e 
Veranopolis, apresentaram os mesmos sintomas para ambas as estirpes de $M$. graminicola (Figura 30).

\subsubsection{Colonização de M. graminicola em trigo}

As observações realizadas no primeiro e quinto dias após a inoculação (dai) permitiram visualizar o início da germinação dos esporos da linhagem B3-GFP nas duas variedades de trigo: resistente (Tonic) e suscetível (Taichung) e na não hospedeira (cevada), não sendo possível apontar diferenças evidentes entre as mesmas (Figura 31). Embora os esporos possam se aderir à toda superfície da folha, eles foram mais visíveis nas depressões estomáticas (Figura 31D, E, F, H e I). A penetração através das aberturas dos estômatos foi visualizada a partir do quinto dai nas duas variedades de trigo resistente e suscetível (Figura 31E e H). Nenhuma estrutura especializada de penetração foi formada e a ação ocorreu por meio de hifas de penetração. Dez dias após a inoculação a cadeia de micélio se estendeu longitudinalmente nas duas hospedeiras e na variedade de cevada, ainda sendo possível visualizar a penetração de hifas nas duas variedades de trigo (Figura 31C, F e I). No $14^{\circ}$ dai, algumas diferenças entre os genótipos foram mais evidentes uma vez que a variedade resistente e a não hospedeira não mostraram evolução no desenvolvimento do fungo e no aparecimento de sintomas nas plantas. Já na variedade suscetível, além das hifas de penetração na abertura dos estômatos (Figura 32A e B),

algumas regiões da folha, em torno dos estômatos, exibiram injúrias como descoloração das células do mesófilo, próximas aos sítios de infecção do patógeno (Figura $32 \mathrm{C}$ e D). No $21^{\circ}$ dai, o desenvolvimento do patógeno na cultivar resistente e na não hospedeira cevada permaneceu inalterado assim como a ausência de sintomas nas plantas. $\mathrm{Na}$ cultivar suscetível, foram observadas regiões do tecido foliar completamente necrosadas com desenvolvimento de picnídios distribuídos por toda a área lesionada. Estruturas mucilaginosas, denominadas cirrhi, que armazenam os picnidiósporos, emergiram dos picnídios (Figura 33). 

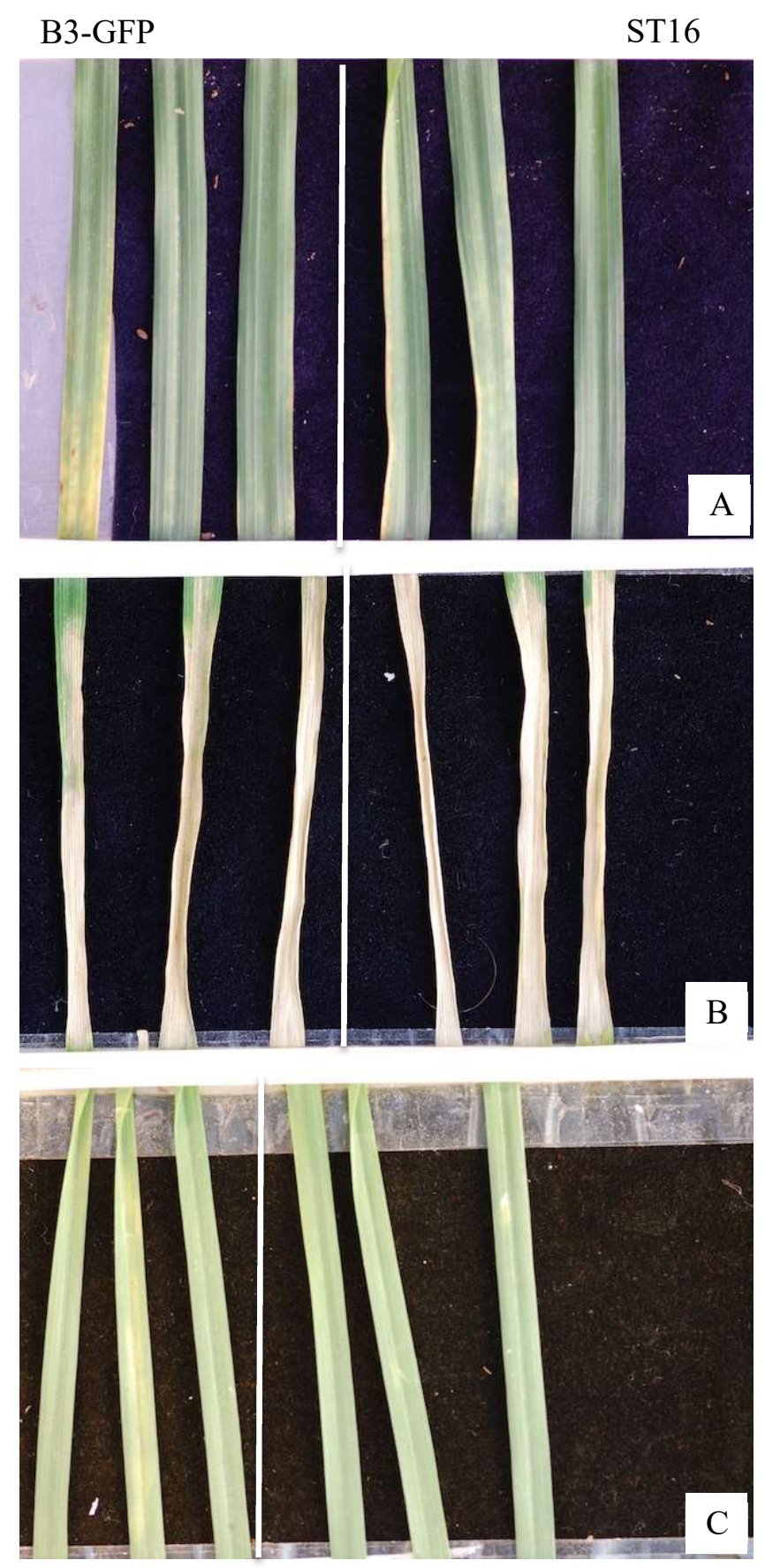

Figura 30. Suscetibilidade de cultivares de trigo às estirpes de Mycosphaerella graminicola B3-GFP e ST16. A. Não hospedeira: cevada Atlas; B. cultivar suscetível: Taichung; C. cultivar resistente: Tonic. 


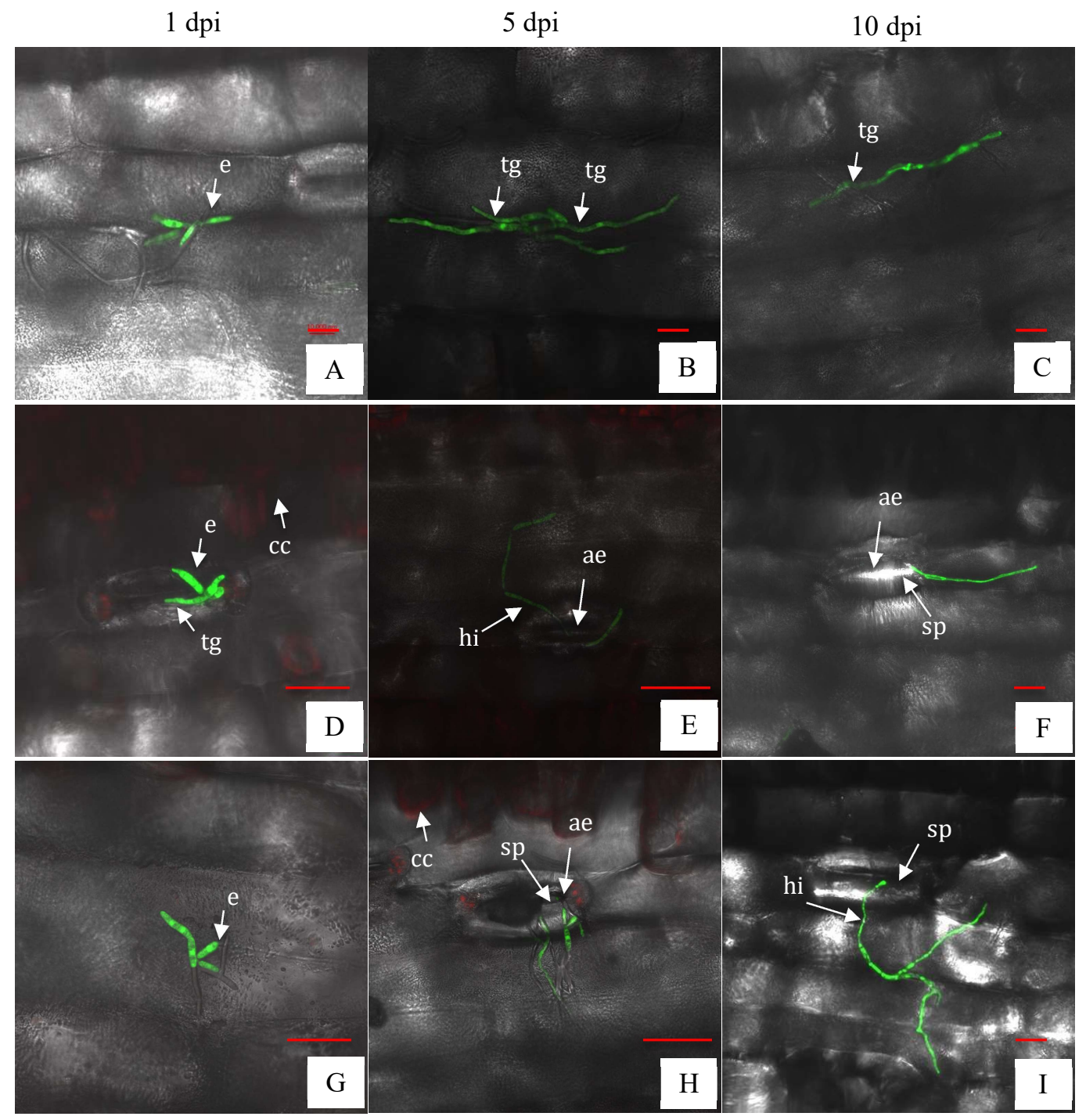

Figura 31. Infecção e colonização da linhagem de Mycosphaerella graminicola B3-GFP em folhas de cevada (A, B e C), trigo resistente (D, E e F) e suscetível (G, H e I) nos dias 1, 5, e 10 após a inoculação (dpi). A, B e C, aderência dos esporos (e) na superfície da folha e próximo aos estômatos (e), com início da formação do tubo germinativo (tg). B e C, formação do tubo germinativo (tg). E, F, H e I, penetração das hifas de infecção (hi) através da abertura dos estômatos (ae), nos sítios de penetração (sp). D e H, células do mesófilo com clorofila vermelho fluorescente (cc). Escalas das barras: menores $=10 \mu \mathrm{m}$, maiores $=20 \mu \mathrm{m}$. 

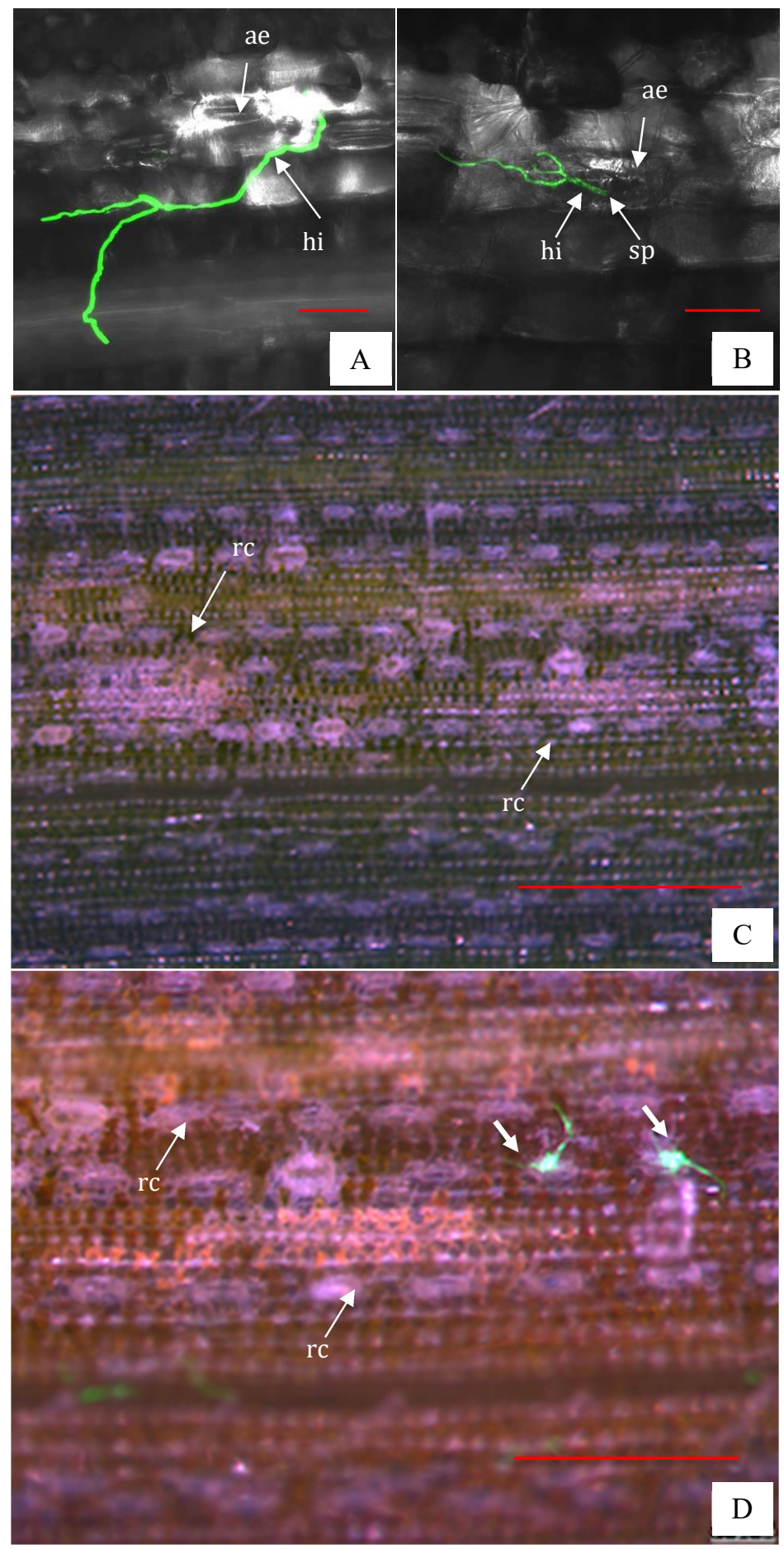

Figura 32. Colonização da linhagem de Mycosphaerella graminicola B3-GFP em folhas de trigo suscetível no $14^{\circ}$ dai. A e $\mathrm{B}$, hifas de infecção (hi) nos sítios de penetração (sp) na abertura dos estômatos (ae). B e $\mathrm{C}$, regiões cloróticas (rc) formadas próximas à área de colonização do fungo (setas). Escala das barras: menores $=20 \mu \mathrm{m}$, maiores $=250 \mu \mathrm{m}$. 


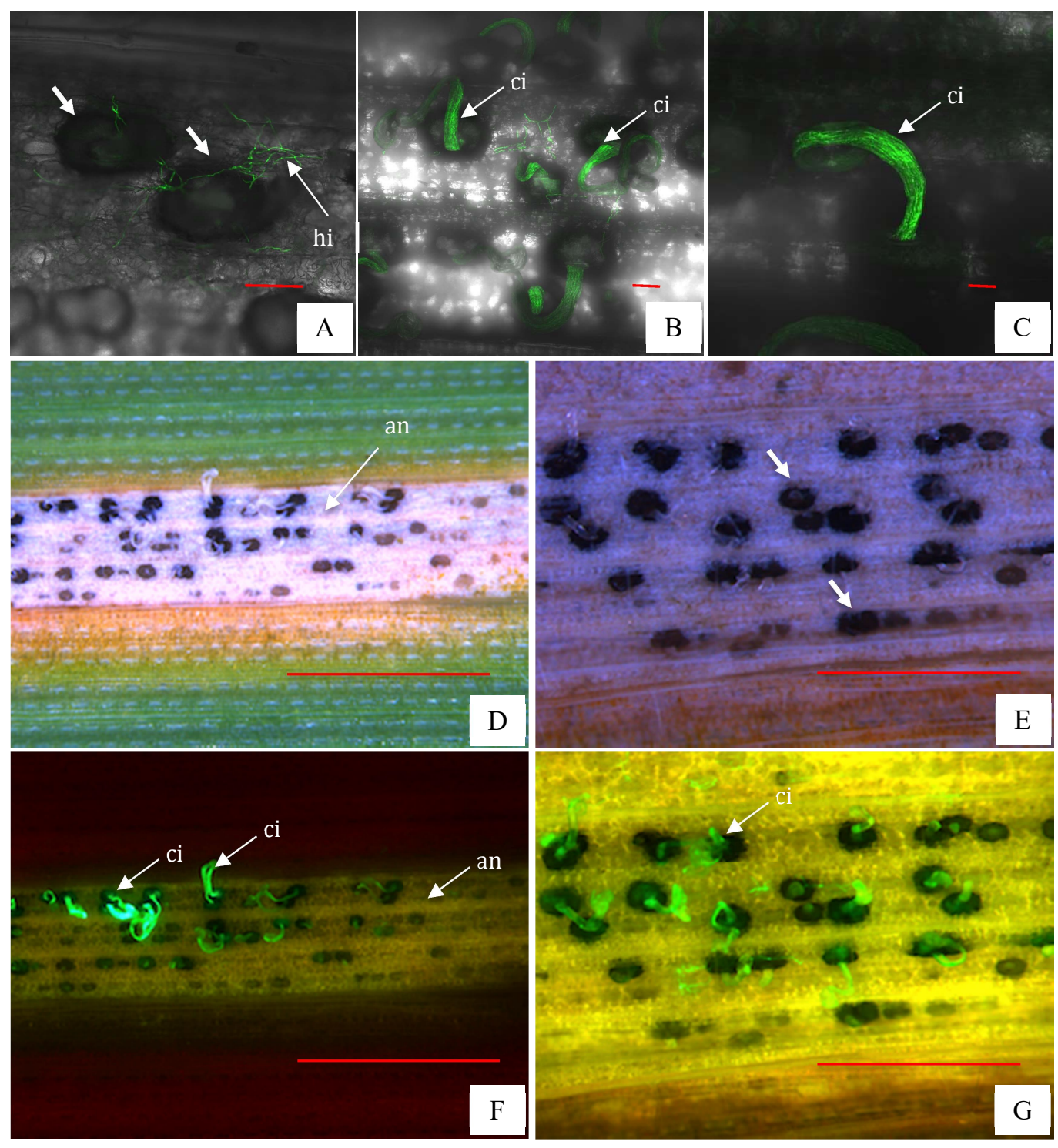

Figura 33. Colonização da linhagem de Mycosphaerella graminicola B3-GFP em folhas de trigo suscetível no 21 dai. A, hifas de infecção (hi) crescendo no mesófilo e picnídios sem cirrhi (setas). B e C, picnídios com emergência de cirrhi (ci) verde fluorescente emergindo. D, E, F e G, picnídios com cirrhi (ci) distribuídos no centro da área necrosada (an). Escala das barras: menores $=5 \mu \mathrm{m}$, intermediária $=10 \mu \mathrm{m}$ e maiores $=250 \mu \mathrm{m}$. 


\subsubsection{Síntese de B3-GFP mutante não funcional para o gene $3 L y s M$}

A inserção dos fragmentos FL1 e FL2 no plasmídeo pCGEN resultou no inserto pCGEN $\triangle 3$ LysM que, analisado por restrição gerou um fragmento de aproximadamente $4.000 \mathrm{pb}$ (Figura 34). A transformação de A. tumefaciens com o vetor pCGEN $\triangle 3$ LysM foi realizada com sucesso uma vez que a integridade do mesmo foi confirmada com a presença dos fragmentos FL1 e FL2.

A linhagem B3-GFP de M. graminicola teve o inserto integrado em seu genoma via $A$. tumefaciens. Todas as colônias do fungo selecionadas após a transformação, ao contrário da linhagem controle, apresentaram crescimento em meio seletivo contendo timentina e geneticina, eliminando a possibilidade de colônias de $A$. tumefacians e de B3-GFP, sem o fenótipo para resistência ao fungicida, estarem misturadas às colônias de $M$. graminicola transformadas (Figura 35). Entretanto, análises via PCR mostraram que o DNA homólogo não foi integrado no sítio do gene LysM de B3-GFP (Figura 36). A combinação de primers flanqueando a região genômica anterior ao fragmento FL1, não foi capaz de gerar fragmentos via PCR. Contudo, foi possível amplificar o fragmento que compreende parte do segmento FL1 com gene de resitência geneticina. Isso confirma a presença do DNA homólogo de 3LysM no genoma de B3-GFP, porém integrado em uma região desconhecida. 




Figura 34. Análise em gel de agarose exibindo o fragmento FL1+GEN+FL2 inserido no plasmídeo pCGEN $\triangle$ 3LysM.


Figura 35. Colônias de Mycosphaerella graminicola B3 $\triangle 3 \mathrm{LysM}$ em meio YPD contendo geneticina e timentina. A. primeiras colônias fúngicas de possíveis transformantes; B. Subculturas preparadas a partir das primeiras colônias. 

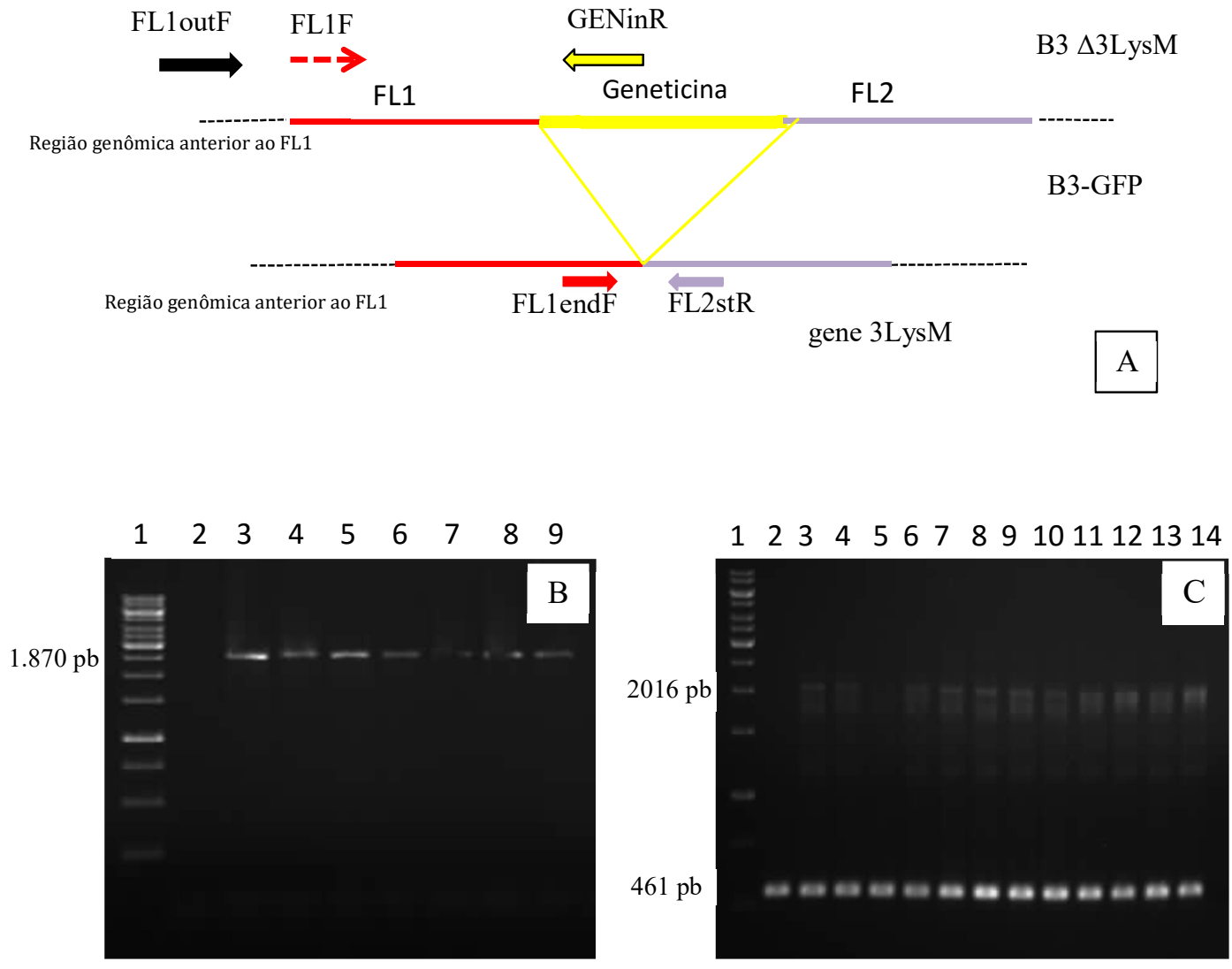

Figura 36. Resultados em gel de agarose, das combinações de primers utilizados para comprovação da transformação de colônias de Mycosphaerella graminicola B3-A3LysM comparados ao controle B3-GFP. A. Esquema representativo das regiões flanqueadas pelos primers; B. primers FL1F e GENinR; C. primers FL1endF e FL2stR. Colunas 1: DNA ladder $1 \mathrm{~Kb}$ da Invitrogen. Colunas 2: B3-GFP (controle). Colunas 3 a 14: colônias de B3- 3 LysM. 


\subsection{Discussão}

A ausência de diferenças entre os sintomas nas variedades de trigo e em cevada colonizadas por B3-GFP e ST16, mostra que GFP não exerceu influência na virulência da linhagem B3-GFP.

As primeiras diferenças marcantes entre as cultivares de trigo suscetíveis e resistentes e a espécie não hospedeira foram observadas a partir do $14^{\circ}$ dai da linhagem B3-GFP, pela formação de áreas cloróticas nas folhas de trigo suscetíveis. Os primeiros sintomas visíveis provocados por M. graminicola em cultivares suscetíveis, iniciaram-se nove dai, com o início da fase necrotrófica do patógeno, manifestando-se como cloroses seguidas por necroses imediatamente anteriores ao desenvolvimento de picnídios e esporulação assexual (Keon et al., 2007; Dean et al., 2012). Durante a etapa que precede os primeiros sintomas visíveis na hospedeira, $M$. graminicola alimenta-se biotroficamente e passa por uma longa fase assintomática, de 10 a 14 dias, período em que se inicia a colonização da cavidade subestomática e do apoplasto em torno do mesófilo da folha. Durante esse período a biomassa fúngica permanece baixa com aumento considerável ocorrendo apenas durante $\mathrm{o}$ desenvolvimento e avanço dos sintomas da doença (Keon et al., 2007; Dean et al., 2012). Assim como M. graminicola, M. musicola também é hemibiotrófico e exibe uma fase assintomática e cloroses que dão início à fase necrotrófica do fungo. Sabe-se que a transição da condição nutricional de M. graminicola de biotrófico para necrotrófico se dá pela produção de alguma forma de toxina ou elicitor ainda não identificada que estimula a morte celular na hospedeira e facilita a esporulação (Kema et al., 1996).

Embora as hifas de penetração de B3-GFP tenham sido identificadas próximas aos estômatos cinco dai, sabe-se que a penetração na folha ocorre através dos estômatos três dai (Kema et al., 1996). Entretanto, Rohel e colaboradores (2001), ao avaliarem uma linhagem de $M$. graminicola transformada com GFP, registraram o início da penetração em folhas de trigo um dai, sem formação de apressórios. Os mesmos autores observaram evidências que indicam a ocorrência de penetração 
direta, apesar da penetração de M. graminicola ter sido exclusivamente por estômatos. Semelhante a M. graminicola, hifas de $M$. musicola foram observadas penetrando a cavidade estomática de folha de bananeira suscetível (Cavendish Grand Naine) 6 dai (Passos et al., 2013).

As observações permitiram concluir que a linhagem B3-GFP expressa com eficiência a proteína verde fluorescente durante a interação com folhas de trigo o que permitem o acompanhamento da colonização do patógeno, tornando viável a continuidade do trabalho numa dimensão de observação mais aprofundada, haja visto que as imagens obtidas no presente estudo foram de regiões superficiais de folhas de trigo.

Algumas tentativas de observação no interior do tecido foliar infectado foram realizadas neste experimento. Entretanto, as lesões necróticas são intimamente relacionadas à perda drástica da integridade da membrana (Keon et al., 2007) o que dificultou a realização de cortes transversais para as avaliações mais detalhadas da colonização. No início da colonização, a cortes transversais também foram inviáveis devido a ausência de sintomas que sinalizassem a região a ser observada.

Embora a transformação de $A$. tumefaciens com o vetor pCGEN $\Delta 3$ LysM construído tenham sido obtida, não foi gerada uma linhagem de $M$. graminicola B3GFP com 3LysM não funcional. A presença dos FL1, FL2 e o gene de resistência geneticina no genoma da linhagem B3-GFP mostra que o inserto foi transferido com sucesso. Entretanto, a inserção parece não ter ocorrido na região esperada, uma vez que a amplificação com o conjunto de primers para a área fora dos limites do gene LysM, não gerou amplicons.

A disrupção ou substituição de genes é uma importante ferramenta para avaliar seu papel na patogênese. O método requer não apenas um eficiente sistema de transformação mas também uma eficiente homologia de recombinação do gene alvo, o que já foi considerado um evento raro. Dependendo da linhagem usada, a transformação pode se tornar ineficiente e irreproduzível (Zwiers \& Waard, 2001). Embora o presente estudo tenha sido pioneiro para a geração do gene 3LysM inativo 
em B3-GFP, a linhagem de M. graminicola já foi utilizada para a transformação de outros genes alvos, via protoplasto (Payne et al., 1998; Rohel et al., 2001).

A transformação de $M$. graminicola mediada por A. tumefaciens é relativamente recente, comparada a leveduras como Saccharomyces cerevisiae e Kluyveromyces lactis (Bundock et al., 1995, 1999). O método vem sendo utilizado e aperfeiçoado para a transformação de $M$. graminicola desde o início da última década. Zwiers \& Waard (2001) utilizaram construct (vetores com insertos de interesse) para causar a disrupção do gene transportador $\mathrm{ABC}(M g A t r 2)$ - que codifica proteínas que promovem proteção contra agentes químicos, gerando linhagens com genes inativos com alta eficiência. No presente estudo, é provável que o resultado da transformação esteja relacionado com uma possível ineficiência de integração do fragmento de DNA homólogo, por ausência de homologia com o gene alvo de B3-GFP.

De acordo com Zwiers \& Waard (2001), recombinação homóloga em $M$. graminicola parece ser dependente do tamanho da sequência homóloga, uma vez que o uso de construct contendo DNA homólogo menor que $2.2 \mathrm{~kb}$ nunca levou ao sucesso da disrupção de MgAtr2, sugerindo que seja necessário uma região flanqueada relativamente longa para que a transformação ocorra com eficiência. Essa possibilidade não se aplica ao presente estudo, uma vez que o construct carregava um fragmento de DNA homólogo de aproximadamente $4 \mathrm{~kb}$.

Ao invés da recombinação homóloga, a integração ectópica parece ter ocorrido no presente estudo. Este é o modo mais comum de transformação, onde o gene transformante é integrado a alguma região do genoma devido a um simples crossing over entre o plasmídio e o sítio cromossômico não homólogo (Mannarelli \& Lacks, 1984; Fincham, 1989). Isso justificaria o resultado obtido pois, embora a inserção do gene no sítio alvo não tenha sido comprovada, colônias da linhagem B3GFP transformada com o gene 3LysM inativo foram capazes de crescer em meio seletivo com antibiótico geneticina e tiveram a presença do gene de resistência para o fungicida confirmada no seu genoma, via PCR.

Apesar dessa análise ter sido a primeira tentativa de nocaute do gene efetor 3LysM na linhagem B3-GFP de M. graminicola, em IPO323, o nocaute do gene já foi 
obtido através do sistema de transformação mediado por A. tumefaciens (Marshall et al., 2011). Portanto, novas tentativas devem ser realizadas a fim de otimizar a técnica de transformação de B3-GFP mediada por Agrobacterium para a obtenção do gene 3 LysM inativo, seja por ajustes relacionados à linhagem utilizada, à duração do cocultivo ou à densidade de células de Agrobacterium (Chen et al., 2000; Mullins et al., 2001).

Um alinhamento entre as regiões LysM de M. graminicola e M. fijiensis, utilizando os programas Geneious, revelou grande divergência entre essas regiões genômicas, com apenas 31\% de identidade (Figura 37). Entretando, ambas regiões estão correlacionadas com a captura de carboidratos nas duas espécies. Por $M$. musicola apresentar características biológicas semelhantes à M. graminicola e, principalmente à $M$. fijiensis, uma investigação sobre a influência de LysM na patogênese do fungo deve ser considerada. 




Figura 37. Alinhamento entre as sequências de nucleotídeos das regiões LysM de Mycosphaerella fijiensis e Mycosphaerella graminicola.

\subsection{Conclusão}

A virulência da linhagem B3-GFP de M. graminicola não é influenciada pela presença de GFP no seu genoma. B3-GFP expressa com eficiência a proteína fluorescente durante o processo de colonização, permitindo o acompanhamento da colonização do patógeno durante todo o ciclo de infecção. Os resultados obtidos são importantes informações para a futura investigação da influência do gene 3 LysM na patogênese de M. graminicola, para responder questões intrigantes acerca do momento em que esse efetor se torna fundamental ou não para a colonização, principalmente no que diz respeito à fase assintomática. 


\section{Conclusão geral e perspectivas futuras}

A variabilidade genética entre os indivíduos de $M$. musicola de uma mesma população é maior do que entre indivíduos de populações diferentes. Esse fato está correlacionado com a presença de recombinação sexual entre os indivíduos dentro das populações e com o fluxo gênico entre as mesmas, processos evidenciados no trabalho. Mais estudos a respeito da estrutura genética de M. musicola devem ser realizados de modo a proporcionar uma cobertura de todas as áreas produtoras de bananeiras no Brasil e com maior equilíbrio na amostragem entre locais distintos. Com essa abrangência, além de se conhecer o perfil de diversidade genética entre populações de M. musicola distribuídas em todo o país, será possível retratar com maior clareza como o patógeno está sendo disperso entre áreas geograficamente distantes: se por um processo natural (esporos) ou por ação antrópica. Isso poderá contribuir com a elaboração de estratégias de controle mais bem definidas, não só para M. musicola, já disseminado em todas as áreas produtoras, mas também para a prevenção da chegada de $M$. fijiensis em áreas onde esse patógeno ainda não foi identificado, como o Centro-oeste.

Além disso, os isolados de M. musicola aqui analisados apresentaram um ponto de mutação no gene CYP51 e este pode estar correlacionado à baixa sensibilidade aos fungicidas avaliados. As avaliações se limitaram a poucos isolados de algumas populações. Portanto, mais análises estão previstas para serem desenvolvidas com um número maior de isolados frente a outros grupos químicos, como os QoIs (estrobilurinas), também utilizados no controle de Sigatoka-amarela. A elucidação dos mecanismos de resistência com um subsequente desenvolvimento de diagnóstico baseado em DNA-específico, tais como, a quantificação de alelos específicos baseado em PCR quantitativo em tempo real e o pirosequenciamento de SNP, poderá aprimorar a detecção e quantificação de alelos de resistência a fungicidas em amostras de plantas e auxiliar na tomada de decisões sobre a escolha de fungicidas, dosagem e formulações.

Devido à escassez de estudos em torno da estrutura molecular de M. musicola, sobretudo dos efetores de virulência, a utilização de espécies relacionadas, como $M$. graminicola, torna-se fundamental como referência. Por essa razão, embora a linhagem B3-GFP de M. graminicola com 3 LysM não funcional não tenha sido 
gerada, o aprendizado no desenvolvimento das metodologias foi de extrema relevância para se vislumbrar uma possível aplicação para M. musicola, dado que o gene LysM já foi identificado entre transcritos de folha de Musa sp. durante a interação com o patógeno. 


\section{Referências Bibliográficas}

An GE, Ebert RR, Mitra A, Ha SB (1988) Binary Vectors. In: "Plant Molecular Biology Manual", (Eds.): Gelvin, S. B. and Schilperoort, R. A. Kluwer Academic Publishers, Dordrecht, 1-19.

Agapow PM, Burt A (2001) Indices of multilocus linkage disequilibrium. Molecular Ecology Notes, 1, 101-102.

Aguirre-Gaviria MC, Castaño-Zapata J, Zuluaga-Arias LE (1999) A rapid method for the diagnosis of Mycosphaerella musicola Leach and M. fijiensis Morelet, the causal agents of yellow Sigatoka and black Sigatoka. Infomusa, 8: 7-9.

Ahn SH, Henderson KA, Keeney S, Allis CD (2005) H2B (Ser10) phosphorylation is induced during apoptosis and meiosis in S. cerevisiae. Cell Cycle, 4 (6): 780-783.

Akcapinar GB, Kappel L, Sezerman OU, Seidl-Seiboth V (2015) Molecular diversity of LysM carbohydrate-binding motifs in fungi. Current Genetics, 61 (2): 103-113.

Ali S, Bakkeren G (2011) Fungal and oomycete effectors - strategies to subdue a host. Can. J. Plant Pathology 33(4): 425-446.

Allendorf FW, Luikart G (2007) Conservation and the Genetics of Populations. Blackwell Publishing, 642p.

Amil AF, Heaney SP, Stanger C, Shaw MW (2007) Dynamics of QoI sensitivity in Mycosphaerella fijiensis in Costa Rica during 2000 to 2003. Phytopathology, 97:1451-1457 
Antonovics J (1968) Evolution in closely adjacent plant populations. IV. Manifold effects of gene flow. Heredity, 23: 507-524.

Araújo AG, Borges do Val, AD, Soares, JDR, Rodrigues FA, Pasqual M, Rocha HS, Asmar SA, Codeiro ZJM, Silva SO (2014) Host-pathogen interactions of Musa spp. and Mycosphaerella musicola with epidemiological variables and leaf anatomy within the pathosystem of Yellow Sigatoka disease. Australian Journal of Crop Science, 8(8): 1200-1209.

Arzanlou M, Abeln ECA, Kema GHJ, Waalwijk C, Carlier J, de Vries I, Guzmán M, Crous PW (2007) Molecular diagnostics for the Sigatoka disease complex of banana. Phytopathology, 97:1112-1118.

Arzanlou M, Crous PW, Zwiers LH (2010) Evolutionary dynamics of mating-type loci of Mycosphaerella spp. occurring on banana. Eukaryotic Cell: 164-172.

Arzanlou M, Groenewald JZ, Fullerton RA, Abeln ECA, Carlier J, Zapater MF, Buddenhagen IW, Viljoen A, Crous PW (2008) Multiple gene genealogies and phenotypic characters differentiate several novel species of Mycosphaerella and related anamorphs on banana. Persoonia, 20: 19-37.

Bartlett DW, Clough JM, Godwin JR, Hall AA, Hamer M, Parr-Dobrzanski B (2002) The strobilurin fungicides. Pest Management Science, 58, 649-662.

Bean TP, Cools HJ, Lucas JA, Hawkins ND, Ward JL, Shaw MW, Fraaije BA (2009) Sterol content analysis suggests altered eburicol 14 $\alpha$-demethylase (CYP51) activity in isolates of Mycosphaerella graminicola adapted to azole fungicides. FEMS Microbiology Letters, 297: 266-273

Becher R, Wirsel SGR (2012) Fungal cytochrome P450 sterol 14a-demethylase (CYP51) and azole resistance in plant and human pathogens. Applied Microbiology 
and Biotechnology, 95: 825-40.

Berraies S, Gharbi MS, Belzile F, Yahyaoui A, Hajlaoui MR, Trifi M, Jean M, Rezgui S (2013) High genetic diversity of Mycospaherella graminicola (Zymoseptoria tritici) from a single wheat field in Tunisia as revealed by SSR markers. African Journal of Biotechnology, 12(12): 1344-1349.

Blaalid R, Kumar S, Nilsson RH, Abarenkov K, Kirk PM, Kauserud H (2013) ITS1 versus ITS2 as DNA metabarcodes for fungi. Molecular Ecology Resources, 1-7.

Boller T, He SY (2009) Innate immunity in plants: an arms race between pattern recognition receptors in plants and effectors in microbial pathogens. Science, 324:742-744.

Bolton MD, Van Esse HP, Vossen JH, de Jonge R, Stergiopoulos I, Stulemeijer IJE et al. (2008). The novel Cladosporium fulvum lysin motif effector ECP6 is a virulence factor with orthologues in other fungal species. Molecular Microbiology., 69, 119 136.

Brent KJ, Hollomon DW (2007) Fungicide resistance: the assessment of risk. FRAC Monograph n.2 second edition.

Brown JKM, Hovmoller MS (2002) Epidemiology—aerial dispersal of pathogens on the global and continental scales and its impact on plant disease. Science, 297, 537541.

Bundock P, Den Dulk Ras A, Beijersbergen A, Hooykaas PJJ (1995) Trans-kingdom T-DNA transfer from Agrobacterium tumefaciens to Saccharomyces cerevisiae. The EMBO Jounal, 14: 3206 -3214 
Bundock P, Mroczek K, Winkler AA, Steensma HY, Hooykaas PJJ (1999) T-DNA from Agrobacterium tumefaciens as an effcient tool for gene targeting in Kluyveromyces lactis. Molecular Genetics and Genomics 261: 115-121.

Cañas-Gutiérrez GP, Angarita-Velásquez MJ, $\square$ Restrepo-Flórez JM, Rodríguez P, Moreno CX, Arango R (2009) Analysis of the CYP51 gene and encoded protein in propiconazole-resistant isolates of Mycosphaerella fijiensis. Pest Management Science, 65: 892-899.

Carbone I, Kohn LM (1999) A method for designing primer sets for speciation studies in filamentous ascomycetes. Mycologia, 91: 553 - 556.

Carlier J, Lebrun MH, Zapater MF, Dubois C, Mourichon X (1996) Genetic structure of the global population of banana black leaf streak fungus, Mycosphaerella fijiensis. Molecular Ecology, 5, 499-510.

Carlier J, Mourichom X, Gonzales de León D, Zapater MF, Lebrun MH (1994). DNA restriction fragment length polymorphisms in Mycosphaerella sp. causing banana leaf spot diseases. Molecular Plant Patholology, 84: 751-756.

Carlier J, Zapater MF, Lapeyre F, Jones DR, Mourichon X (2000) Septoria leaf spot of banana: a newly discovered disease caused by Mycosphaerella eumusae (anamorph Septoria eumusae). Phytopathology, 90: 884-890.

Chambers GK, MacAvoy ES (2000) Microsatellites: consensus and controversy. Comparative Biochemistry and Physiology: 455-476.

Cheesman EE (1947) Classification of the bananas. II. The genus Musa L. Kew Bulletin 2: 106-117. 
Chen X, Stone M, Schlagnhaufer C, Romaine CP (2000) A fruiting body tissue method for efficient Agrobacterium-mediated transformation of Agaricus bisporus. Applied and Environment Microbiology, 66: 4510-4513.

Chong P, Arango R, Stergiopoulos I, Guzmán M, Crous PW, da Silva GF, De Wit PJGM, Kema GHJ (2011) Analysis of azole fungicide resistance in Mycosphaerella fijiensis, causal agent of Black Sigatoka. In: Dehne HW, Deising HB, Gisi U, Kuck KH, Russell PE, Lyr H, eds. Modern Fungicides and Antifungal Compounds VI: Proceedings of the 16th International Reinhardsbrunn Symposium on Modern Fungicides and Antifungal Compounds. Braunschweig, Germany: Deutsche Phytomedizinische Gesellschaft, 217-22.

Churchill ACL (2011) Mycosphaerella fijiensis, the black leaf streak pathogen of banana: progress towards understanding pathogen biology and detection, disease development, and the challenges of control. Molecular Plant Pathology, 12: 307-328.

Conde-Ferráez L, Grijalva-Arango R, Canto-Canché B, Manzo-Sánchez G, CanulSalazar MI, James AC (2010) The development of mating type-specific primers for Mycosphaerella fijiensis, the causal agent of black Sigatoka of banana, and analysis of the frequency of idiomorph types in Mexican populations. Australasian Plant Pathology, 39: 1-9.

Conde-Ferraez L, Waalwijk C, Canto-Canche B, Kema GHJ, Crous PW, James AC, Abeln ECA (2007) Isolation and characterization of the mating type locus of Mycosphaerella fijiensis, the causal agent of black leaf streak disease of banana. Molecular Plant Pathology, 8:111-120.

Cools HJ, Fraaije BA (2008) Are azole fungicides losing ground against Septoria wheat disease? Resistance mechanisms in Mycosphaerella graminicola. Pest Management Science, 64: 681-4. 
Cools HJ, Fraaije BA (2013) Update on mechanisms of azole resistance in Mycosphaerella graminicola and implications for future control. Pest Management Science, 69: 150-5.

Cools HJ, Fraaije BA, Lucas JA (2005) Molecular mechanisms correlated with changes in triazole sensitivity in isolates of Mycosphaerella graminicola. Proceedings of the BCPC Congress, Crop Science and Technology, 1: 267-274.

Cools HJ, Hawkins NJ, Fraaije BA (2013) Constraints on the evolution of azole resistance in plant pathogenic fungi. Plant Pathology, 62: 36-42.

Cools HJ, Mullins JGL, Fraaije BA, Parker JE, Kelly DE, Lucas JA, Kelly SL (2011) Impact of recently emerged sterol 14 $\alpha$-demethylase (CYP51) variants of Mycosphaerella graminicola on azole fungicide sensitivity. Applied and Environmental Microbiology, 77 (11): 3830-3837.

Cools HJ, Parker JE, Kelly DE, Lucas JA, Fraaije BA, Kelly SL (2010) Heterologous expression of mutated eburicol 14a-demethylase (CYP51) proteins of Mycosphaerella graminicola to assess effects on azole fungicide sensitivity and intrinsic protein function. Applied and Environmental Microbiology, 76: 2866-72.

Cordeiro ZJM (2007) Panorama Nacional das Principais Doenças da Bananeira. In: Núcleo de Estudos em Fitopatologia (org.), Manejo integrado de doenças de fruteiras. Universidade Federal de Lavras: Sociedade Brasileira de Fitopatologia, 165-184.

Cordeiro, ZJM (1999) Doenças fúngicas da bananeira: Sigatoka amarela, Sigatoka negra e Mal-do-Panamá. Summa Phytopathologica, 25 (1): 58-60. 
Cordeiro, ZJM; Kimati, H (1997) Doenças da bananeira (Musa spp) In: Kimati, H; Amorim, L; Bergamim Filho, A; Camargo, LEA; Rezende, JAM. Manual de Fitopatologia, 2 (13): 112-136.

Cordeiro MZJ, Matos PA (2003) Impact of Mycosphaerella spp. in Brazil. In: Mycosphaerella Leaf Spot Diseases of Bananas: Present Status and Outlook. Proceedings of the Workshop on Mycosphaerella Leaf Spot Diseases, San José, Costa Rica, 20-23 May 2002 (Jacome, L., Lepoivre, P., Marin, D., Ortiz, R., Romero, R. and Escalant, J.V., eds), pp. 91-97. Montpellier: The International Network for the Improvement of Banana and Plantain.

Cordeiro, ZJM, Rocha RS, Araújo AG (2011) Metodologias para manuseio de Mycosphaerella musicola em laboratório. Documentos 198, Embrapa Mandioca e Fruticultura.

Crous PW, Groenewald JZ, Pongpanich K, Himaman W, Arzanlou M, Wingfield $\square$ MJ (2004) Cryptic $\square$ speciation and host specificity among Mycosphaerella spp. occurring on Australian Acacia species grown as exotics in the tropics. Studies in Mycology, 50: 457-469.

Crous PW, Kang JC, Braun U (2001) A phylogenetic redefinition of anamorph genera in Mycosphaerella based on ITS rDNA sequence and morphology. Mycologia 93: $1081-1101$.

Crous PW, Schoch CL, Hyde KD, Wood AR, Gueidan C, De Hoog GS, Groenewald JZ (2009) Phylogenetic lineages in the Capnodiales. Studies Mycology, 64: 17-47.

Crous PW, Tanaka K, Summerell BA, Groenewald JZ (2011) Additions to Mycosphaerella complex. IMA Fungus, 2 (1): 49-64. 
Daniel HM, Sorrell TC, Meyer W (2001) Partial sequence analysis of the actin gene and its potential for studying the phylogeny of Candida species and their teleomorphs. Interna- tional Journal of Systematic and Evolutionary Microbiology, 51: 1593 1606.

Dantas LL, Shepherd K, Oliveira e Silva, S, Soares Filho, WS (1997) Classificação botânica, origem, evolução e distribuição geográfica. In: Alves EJ (org.). A cultura da banana: aspectos técnicos, socioeconômicos e agroindustriais. Brasília, DF: Embrapa; Cruz das Almas: Embrapa-CNPMF, 587 p.

Dean R, Van Kan JA, Pretorius ZA, Hammond-Kosack KE, Di Pietro A, Spanu PD, Rudd JJ, Dickman M, Kahmann R, Ellis J, Foster GD (2012) The top 10 fungal pathogens in molecular plant pathology. Molecular Plant Pathology, 12: 414-430.

Debuchy R, Turgeon BG (2006) Mating-type structure, evolution and function in euascomycetes. 293-323 In: The Mycota I. growth, differentiation and sexuality. Kües U, Fischer R, eds. Berlin, Heidelberg; Springer pub.

de Jonge R, van Esse HP, Kombrink A, Shinya T, Desaki Y, Bours R, van der Krol S, Shibuya N, Joosten MH, Thomma BP (2010) Conserved fungal LysM effector Ecp6 prevents chitin-triggered immunity in plants. Science, 329: 953-955.

de Jonge R, Thomma BPHJ (2009) Fungal LysM effectors: extinguishers of host immunity? Trends Microbiology, 17: 151-157.

Doyle JJ, Doyle JL (1987) Isolation of plant DNA from fresh tissue. Focus, Gaithersburg, 12: 13-15.

Ehr RJ, Kemmitt G. (2002) Periodic table of the fungicides. Indianapolis: Dow Agrosciences. 
Excoffier L, Lischer HEL (2010) Arlequin suite ver 3.5: a new series of programs to perform population genetics analyses under Linux and Windows. Molecular Ecology Resources, 10: 564-567.

Eyal, Z. (1999) The Septoria tritici and Stagonospora nodorum blotch diseases of wheat. European Journal of Plant Pathology, 105: 629-641.

Eyal Z, Sharen AL, Prescott JM, van Ginkel M (1987) The Septoria diseases of wheat: concepts and methods of disease management. Mexico, DF, CIMMYT.

FAOSTAT (2011) Disponível em:

$<$ http://faostat.fao.org/site/368/DesktopDefault.aspx?PageID=368\#ancor $>$ Acesso em: setembro de 2014.

FAOSTAT (2012) Disponível em:

$<$ http://faostat.fao.org/site/339/default.aspx> Acesso em: setembro de 2014.

FAOSTAT (2013) Disponível em:

$<$ http://faostat3.fao.org/browse/Q/QC/E> Acesso em: Fevereiro de 2015.

Ferreira ME, Colombo AL, Paulsen I, Ren Q, Wortman J, et al. (2005) The ergosterol biosynthesis pathway, transporter genes, and azole resistance in Aspergillus fumigatus. Medical Mycology, 43 Supplement, 1: S 313-319.

Fincham JRS (1989) Transformation in fungi. Microbiological Reviews, 53: 148-170.

Forcelini CA (1994) Fungicidas inibidores da síntese de esteróis. I. triazoles. Revisão Anual de Patologia de Plantas, 2: 335-355. 
Fournier E, Giraud T (2008) Sympatric genetic differentiation of a generalist pathogenic fungus, Botrytis cinerea, on two different host plants, grapevine and bramble. Journal of Evolutionary Biology, 21: 122-132.

Fraaije BA, Bayon C, Atkins S, Cools HJ, Lucas JA \& Fraaije MW (2012) Risk assessment studies on Succinate Dehydrogenase Inhibitors, the new weapons in the battle to control Septoria leaf blotch in wheat. Molecular Plant Pathology, 13: 263275.

Fraaije BA, Butters JA, Coelho JM, Johes DR, Hollomon DW (2002) Following the dynamics of strobilurin resistance in Blumeria graminis f. sp. tritici using quantitative allele-specific real-time PCR measurements with the fluorescente dye SYBR green I. Plant Pathology, 51: 45-54.

Freeland JR (2005) Molecular Ecology. Ed. John Wiley \& Sons Ltd. 403p.

Gasparotto L, Pereira JCR, Costa MM, Pereira MCN (2001) Fungicidas para o controle da Sigatoka negra da bananeira. Fitopatologia Brasileira 26, 434 (Abstract 636).

Gasparotto L, Pereira JCR, Hanada RE, Montarroyos AVV (2006) Sigatoka-negra da bananeira. Brasília, Embrapa, 177 p.

Gerber S, Mariette S, Streiff R, Bodenes C, Kremer A (2000) Comparison of microsatellites and amplified fragment length polymorphism markers for parentage analysis. Molecular Ecology, 9: 1037-1048.

Gisi U, Sierotzki H, Cook A, McCaffery A (2002) Mechanisms influencing the evolution of resistance to Qo inhibitor fungicides. Pest Management Science, 58: 859867. 
Goldstein DB, Pollock DD (1997) Launching microsatellites: a review of mutation processes and methods of phylogenetic inference. Journal of Heredity, 88: 335-342.

Gomes LIS; Douhan GW, Bibiano LBJ; Maffia LA; Mizubuti ESG (2013) Mycosphaerella musicola Identified as the Only Pathogen of the Sigatoka Disease Complex Present in Minas Gerais State, Plant Disease, 97 (12): 1537-1543.

Goodwin SB (2004) Minimum phylogenetic coverage: An additional criterion to guide the selection of microbial pathogens for initial genomic sequencing efforts. Phytopathology, 94: 800-804.

Goodwin SB, Ben M'Barek S, Dhillon B, Wittenberg A, Crane CF, Hane JK, Foster AJ, Van der Lee TAJ, Grimwood J, Aerts A, et al. (2011) Finished genome of the fungal wheat pathogen Mycosphaerella graminicola reveals dispensome structure, chromosome plasticity, and stealth pathogenesis. PLoS Genetics 7: 1-17.

Goodwin SB, Waalwijk C, Kema GHJ, Cavaletto JR, Zhang G (2003) Cloning and analysis of the mating-type idiomorphs from the barley pathogen Septoria passerinii. Molecular Genetics and Genomics, 269: 1-12.

Goyeau H, Halkett F, Zapater MF, Carlier J, Lannou C (2007) Clonality and host selection in the wheat pathogenic fungus Puccinia triticina. Fungal Genetics and Biology, 44: 474-483.

Gurung S, Goodwin SB, Kabbage M, Bockus WW, Adhikari TB (2011) Genetic Differentiation at Microsatellite Loci Among Populations of Mycosphaerella graminicola from California, Indiana, Kansas, and North Dakota. Phytopathology, 101 (10): 1251-1259. 
Guzmán M (2002) Situación de la Sigatoka negra en Costa Rica y opciones para el manejo de la enfermedad. Acorbat. Memorias XV reunión, Cartagena de Indias, 27 octubre- 2 noviembre 2002, Asociación de Bananeros de Colombia, AUGURA, Medellín, Columbia; 184-192.

Häkkinen M (2013) Reappraisal of sectional taxonomy in Musa (Musaceae). International Association for Plant Taxonomy, 62 (4): 809-813.

Halkett F, Coste D, Rivas Platero GG, Zapater MF, Abadie C, Carlier J (2010) Genetic discontinuities and disequilibria in recently established populations of the plant pathogenic fungus Mycosphaerella fijiensis. Molecular Ecology (2010) 19, 3909-3923.

Hamrick JL (1982) Plant population genetics and evolution. American Journal of Botany, Ohio, 69 (10): 1685-1693.

Hayden HL, Carlier J, Aitken EAB (2003) Population differentiation in the banana leaf spot pathogen Mycosphaerella musicola, examined at a global scale. Plant Pathology, 52: 713-719.

Hayden HL, Carlier J, Aitken EAB (2005) The genetic structure of australian populations of Mycosphaerella musicola suggests restricted gene flow at the continental scale. Phytopathology, 95 (5): 489-498.

Heslop-Harrison JS, Schwarzacher T (2007) Domestication, genomics and the future for banana. Annals of Botany, 100: 1073-1084.

Hightower RC, Meagher RB (1986) The molecular evolution of actin. Genetics, 114: $315-332$. 
Hobbelen P, Paveley N, Fraaije B, Lucas J, van den Bosch F (2011) Derivation and testing of a model to predict selection for fungicide resistance. Plant Pathology, 60: 304-313.

Hsu JY, Sun ZW, Li X, Reuben M, Tatchel K, Bishop DK, Grushcow JM, Brame CJ, Caldwell JA, Hunt DF, Lin R, Smith MM, Allis CD (2000) Mitotic phosphorylation of histone $\mathrm{H} 3$ is governed by Ipl1/aurora kinase and Glc7/PP1 phosphatase in budding yeast and nematodes. Cell, Cambridge, 102 (3): 279-291.

Jacome LH, Schuh W (1993) Spore production and artificial inoculation techniques for Mycosphaerella fijiensis var. difformis. Tropical Agriculture, Trinidad, 70: 33-38.

Jain SK, Bradshaw AD (1966) Evolutionary divergence among adjacent plant populations. I. The evidence and its theoretical analysis. Heredity, 21: 407-441.

James AC, Arzanlou M, Canche BC, Ramirez JH, Conde Ferraez L, Echeverria SP (2010) Fungal Disease of Banana, Chapter 3, 65-122. In: Cohen AE. Bananas: Nutrition, Diseases and Trade Issues. 337p.

Johanson A, Crowhurst RN, Rikkerink EHA, Fullerton RA, Templeton MD (1994) The use of species-specific DNA probes for the identification of Mycosphaerella fijiensis and M. musicola, the causal agents of Sigatoka disease. Plant Pathology, 43: 701-707.

Jones JDG, Dangl JL (2006) The plant immune system. Nature, 444: 323-329.

Kaku H, Nishizawa Y, Ishii-Minami N, Akimoto-Tomiyama C, Dohmae N, Takio K, Minami E, Shibuya N. (2006) Plant cells recognize chitin fragments for defense signaling through a plasma membrane receptor. Proceeding of the National Academy of Science - USA, 103: 11086-11091 
Kalia RK, Rai MK, Kalia S, Singh R, Dhawan AK (2011) Microsatellite markers: an overview of the recent progress in plants. Euphytica, 177: 309-334.

Kema GHJ, Yu DZ, Rijkenberg FHJ, Shaw MW, Baayen RP (1996) Histology of the pathogenesis of Mycosphaerella graminicola in wheat. Phytopathology, 86: 777-786.

Keon J, Antoniw J, Carzaniga R, Deller S, Ward JL, Baker JM, Beale MH, Hammond-Kosack KE, Rudd JJ (2007) Transcriptional adaptation of Mycosphaerella graminicola to programmed cell death (PCD) of its susceptible wheat host. Molecular Plant Microbe Interact, 20: 178-193.

Kiiza BA, Rwomushana G, Lwasa S, Diiro GM (2006) An evaluation of the banana bacterial wilt disease awareness campaign in Uganda. Submitted to United States Agency for International Development and The Danish International Development Agency/Agricultural Sector Programme Support. 55 p.

Kim H, Newell AD, Gota-Sieckmeyer RG, Rupe JC, Fakhoury AM, Bluhm BH (2013) Mating-type distribution and genetic diversity $\square$ of Cercospora sojina populations on soybean $\square$ from arkansas: Evidence for Potential Sexual Reproduction. Phytopathology, 103 (10): 1045-1051.

Kimati H, Galli F (1980) Doenças da bananeira Musa spp. In: MANUAL de Fitopatologia; doenças das plantas cultivadas. São Paulo: Ed. Agronômica Ceres, 2: 87-101.

Kouzarides T (2007) Chromatin modifications and their function. Cell, Cambridge, 128 (4): 693-705. 
Leach R (1946) Banana leaf spot (Mycosphaerella musicola) on the Gros Michel variety in Jamaica. Gov. Printeer. 118p.

Leberg LP (2002) Estimating allelic richness: Effects of sample size and bottlenecks. Molecular Ecology, 11: 2445-2449.

Lee WS, Rudd JJ, Hammond-Kosack KE, Kanyuka K (2014) Mycosphaerella graminicola LysM effector-mediated stealth pathogenesis subverts recognition through both CERK1 and CEBiP homologues in Wheat. Molecular Plant Microbe Interactions, 27 (3): 236-243.

Leite JBV, Silva SO, Alves EJ, Lins RD, Jesus ON (2003) Caracteres da planta e do cacho de genótipos de bananeira, em quatro ciclos de produção, em Belmonte, Bahia. Revista Brasileira de Fruticultura, 25: 443-447.

Lepesheva GI, Waterman MR (2004) CYP51 $\square$ the omnipotent P450. Molecular and Cellular Endocrinology, 215: 165-170.

Leroux P, Walker AS (2011) Multiple mechanisms account for resistance to sterol 14 alpha-demethylation inhibitors in field isolates of Mycosphaerella graminicola. Pest Management Science, 67: 44-59.

Lewis PO, Zaykin D (2001) Genetic Data Analysis: Computer program for the analysis of allelic data.

Linde C, Zhan J, McDonald BA (2002) Population structure of Mycosphaerella graminicola: From lesions to continents. Phytopathology, 92: 946-955.

Luttrell ES (1974) The parasitism of vascular plants. Mycologia, 66: 1-15. 
Ma Z, Michailides TJ (2005) Advances in understanding molecular mechanisms of fungicide resistance and molecular detection of resistant genotypes in phytopathogenic fungi. Crop Protection, 24: 853-863.

Madigan MT, Martinko JM, Dunlap PV, Clark DP (2010) Microbiologia de Brock. 12. ed., Porto Alegre: Artmed, 1160 p.

Mannarelli BM, Lacks SA (1984) Ectopic integration of chromosomal genes in Streptococcus pneumonia. Journal of Bacteriology, 867-873.

Marín DH, Romero RA, Guzmán, M. Sutton TB (2003) Black Sigatoka: an increasing threat to banana cultivation. Plant Disease, 87, 208-222.

Marichal P, Koymans L, Willemsens S, Bellens D, Verhasselt P, et al. (1999) Contribution of mutations in the cytochrome P450 14alpha-demethylase (Erg11p, Cyp51p) to azole resistance in Candida albicans. Microbiology 145: 2701-2713.

Marshall R, Kombrink A, Motteram J, Loza-Reyes E, John Lucas, Hammond-Kosack KE, Thomma BPHJ, Rudd JJ (2011) Analysis of two in planta expressed lysm effector homologs from the fungus Mycosphaerella graminicola reveals novel functional properties and varying contributions to virulence on wheat. Plant Physiology, 156: $756-769$.

Matos AP, Cordeiro ZJM (2011) O patógeno e sua distribuição geográfica. IN: Cordeiro, ZJM, Matos AP, Silva SO (Editores) Recomendações técnicas sobre a Sigatoka-negra da bananeira, Cruz das Almas: Embrapa Mandioca e Fruticultura: 1525 .

McDonald BA, Linde C (2002) The population genetics of plant pathogens and breeding strategies for durable resistance. Euphytica, 124: 163-180. 
McGahan MW, Fulton RH (1964) Leaf spot of banananas caused by Mycosphaerella musicola: A comparative anatomical study of juvenile and adult leaves in relation to lesion morphology. Phytopathology, 55: 1179- 1182.

Medina JC (1995) Banana: cultura, matéria-prima, processamento e aspectos econômicos. 2. ed. Campinas: ITAL, 302p.

Meredith DS (1970) Banana leaf spot disease (Sigatoka) caused by Mycosphaerella musicola. Phytopathology Paper No. 11 Common wealth Mycology Institute, 147p.

Molina C, Kaemmer D, Aponte S, Weising K, Kahl G (2001) Microsatellite markers for the fungal banana pathogen Mycosphaerella musicola Molecular Ecology Notes, 1: 137-139.

Molina C, Kahl G (2002) Genomics of two banana pathogens, genetic diversity, diagnostics,and phylogeny of Mycosphaerella fijiensis and M. musicola. In: JAIN, S.M. (Ed.). Banana improvement, cellular and molecular biology, and induced mutations. Vienna: FAO/IAEA.

Molina CM, Kahl G (2004) Genomics of two banana pathogens: genetic diversity, diagnostics, and phylogeny of Mycosphaerella fijiensis and M. musicola. In: Banana Improvement: Cellular, Molecular Biology, and Induced Mutations. Editors S. Mohan Jain and Rony Swennen, Science Publishers, Inc., Enfield (NH) USA.

Montarroyos, AVV (2005) Análise da diversidade genética e patogênica de Mycosphaerella fijiensis e Mycosphaerella musicola no Brasil. 182 p. Tese (Doutorado em Ciências Biológicas) - Universidade Federal de Pernambuco, Recife.

Moreira RFC, Cordeiro ZJM, Vilarinhos AD (2003) Caracterização genética de 
isolados de Mycosphaerella musicola por marcadores RAPD. Summa Phytopathologica, Botucatu, 29 (3): 275- 277.

Morin PA, Luikart G, Wayne RK (2004) SNPs in ecology, evolution and conservation. Trends in Ecology \& Evolution, 19: 208-216.

Mullins ED, Chen X, Romaine P, Geiser DM, Kang S (2001) Agrobacteriummediated transformation of Fusarium oxysporum: an effcient tool for insertional mutagenesis and gene transfer. Phytopathology, 91: 173-180.

Mullins JGL, Parker JE, Cools HJ, Martel CM, Togawa RC, Lucas JA, Fraaije BA, Kelly DE, Kelly SL (2011) Molecular modelling of the emergence of azole resistance in Mycosphaerella graminicola. PLOS One 6, e20973.

Nei, M (1977) F-statistics and analysis of gene diversity in subdivided population. Annals of Human Genetics, 41: 225-233.

Nei, M (1978) Estimation of average heterozygosity and genetic distance from a small number of individuals. Genetics, Maryland, 89: 583-590.

Nei, M (1987) Molecular evolutionary genetics. New York: Columbia University Press.

Nolting N, Pöggeler S, (2006) Characterization of transcription factors from the filamentous ascomycete Sordaria macrospora and their implications on fruiting-body development. Fungal Genetics Newsletter 52 Supplement.

Oksanen J, Blanchet FG, Kindt R, Legendre P, Minchin PR, O’Hara RB, Simpson GL, Solymos P, Stevens MHH, Wagner H (2013) vegan: Community Ecology Package. $\mathrm{R}$ package version 2.0-7. Disponível em: <http://CRAN.R- 
project.org/package $=$ vegan $>$

Orton, ES (2012) Responses of wheat to infection by Mycosphaerella graminicola. Thesis submitted to the University of East Anglia for the degree of Doctor of Philosophy, John Innes Centre.

Parnell M, Burt PJA, Wilson K (1998) The influence of exposure to ultraviolet radiation in simulated sunlight on ascospores causing black Sigatoka disease of banana and plantain. International Jounal fo Biometeorology, 42 (1): 22-27.

Passos MAN, Cruz VO, Emediato FL, Teixeira CC, $\square$ Azevedo VCR, Brasileiro ACM, Amorim EP, Ferreira CF, Martins NF, Togawa RC, Pappas Júnior GJ, da Silva Jr OB, Miller RNG (2013) Analysis of the leaf transcriptome of Musa acuminata during interaction with Mycosphaerella musicola: gene assembly, annotation and marker development, BMC Genomics, 14:78.

Payne AC, Grosjean-Cournoyer MC, Hollomon DW (1998) Transformation of the phytopathogen Mycosphaerella graminicola to carbendazim and hygromycin B resistance Current Genetics, 34: 100-104.

Perea I, Rodríguez Arango E, Márquez E, Arango R (2005) Genetic diversity of Colombian isolates of Mycosphaerella fijensis Morelet based on microsatellite markers. InfoMusa, 14 (2): 18-21.

Peterson R, Grice K, De La Rue S (2002) Management of Mycosphaerella leaf spot diseases in Australia. In: Jacombe L, Lepoivre P, Marin D, Ortiz R, Romero R, Escalant JV (Eds) Mycosphaerella Leaf Spot of Bananas: Present Status and Outlook, Proceedings of the $2^{\text {nd }}$ International Workshop on Mycosphaerella Leaf Spot Diseases, 20-23 May 2002, San José, Costa Rica: 271-276. 
Pitzschke A, Schikora A, Hirt H (2009) MAPK cascade signalling networks in plant defence, Current Opinion in Plant Biology, 12: 1-6.

Prasanth VP, Chandra S, Jayashree B and Hoisington D. 2006. AlleloBin - A program for allele binning of microsatellite markers based on the alogirithm of Idury and Cardon (1997). ICRISAT. International Crops Research Institute for the SemiArid Tropics.

Prestes AM (2011) Disponível em:

http://www.cnpt.embrapa.br/pesquisa/agromet/pdf/trigo_historia/cap13.pdf . Acesso:

Fevereiro de 2015.

Price EW, Carbone I (2005) SNAP: workbench management tool for evolutionary population genetic analysis. Bioinformatics, 21: 402-404.

Pritchard JK, Stephens M, Donnelly P (2000) Inference of population structure using multilocus genotype data. Genetics, 155: 945-959.

Queiroz CB, Miranda EC, Hanada RE, Sousa NR, Gasparotto L, Soares MA, Silva GF (2013) Distribution of mating-type alleles and M13 PCR markers in the black leaf spot fungus Mycosphaerella fijiensis of bananas in Brazil. Genetics and Molecular Research, 12 (1): 443-452.

Queiroz CB, Santana MF, Silva GF, Mizubuti ESG, Araújo EF, Queiroz MV (2014) Use of the IRAP marker to study genetic variability in Pseudocercospora fijiensis populations. Current Microbiology, 68: 358-364.

Raven PH, Evert RF, Eichhorn SE (2001) Biologia Vegetal, 6a . ed. Coord. Trad. J.E.Kraus. Editora Guanabara Koogan, Rio de Janeiro, 906p. 
Razavi M, Hughes GR (2004) Microsatellite markers provide evidence for sexual reproduction of Mycosphaerella graminicola in Saskatchewan. Genome, 47: 789-94.

Rivas GG, Zapater MF, Abadie C, Carlier J (2004) Founder effects and stochastic dispersal at the continental scale of the fungal pathogen of bananas Mycosphaerella fijiensis. Molecular Ecology, 13: 471-482.

Rohel EA, Payne AC, Fraaije BA, Hollomon DW (2001) Exploring infection of wheat and carbohydrate metabolism in Mycosphaerella graminicola transformants with differentially regulated green fluorescent protein expression. Molecular PlantMicrobe Interactions, 14 (20): 156-163.

Romero RA, Sutton TB (1997): Sensitivity of Mycosphaerella fijiensis, causal agent of black Sigatoka of banana, to propiconazole. Phytopathology, 87: 96-100.

Scalliet G, Bowler J, Luksch T, Kirchhofer-Allan L, Steinhauer D, Ward K, Niklaus M, Verras A, Csukai M, Daina A, Fonne'-Pfister R (2012) Mutagenesis and functional studies with succinate dehydrogenase inhibitors in the wheat pathogen Mycosphaerella graminicola. PLoS ONE 7 (4): e35429.

Schlötterer C (1998) Genome evolution: Are microsatellites really simple sequences? Current Biology, 8:132-134.

Schoch CL, Seifert K, Huhndorf S, Robert V, Spouge JL, Levesque CA, Chen W (2012) Nuclear ribosomal internal transcribed spacer (ITS) region as a universal DNA barcode marker for Fungi. Proceedings of the National Academy of Sciences of the United States of America, 109: 6241-6246.

Selkoe KA, Toonen RJ (2006) Microsatellites for ecologists: a practical guide to 
using and evaluating microsatellite markers. Ecology Letters, 9: 615-629.

Semagn K, Bjornstad A, Ndjiondjop MN (2006) An overview of molecular marker methods for plants. African Journal of Biotechnology, 5 (25): 2540-2568.

Shaw MW, Royle DJ (1989) Airborne inoculum as a major source of Septoria tritici (Mycosphaerella graminicola) infections in winter wheat crops in the UK. Plant Pathology, 38: 35-43.

Shimizu T, Nakano T, Takamizawa D, Desaki Y, Ishii-Minami N, Nishizawa Y, Minami E, Okada K, Yamane H, Kaku H, Shibuya N (2010) Two LysM receptor molecules, CEBiP and OsCERK1, cooperatively regulate chitin elicitor signaling in rice. The Plant Journal, 64: 204-214.

Silva GF, Paixão RDV, Queiroz CB, Santana MF, Souza A, Souza NR, Hanada RE, Gasparotto L (2014) Genetic diversity of Mycosphaerella fijiensis in Brazil analyzed using an ERIC-PCR marker. Genetics and Molecular Research, 13 (3): 7698-7707.

Silva SO, Alves EJ, Shepherd K, Dantas JLL (1997) Cultivares. In: Alves EJ (org). A cultura da banana: aspectos técnicos, socioeconômicos e agroindustriais. Brasília, DF: Embrapa; Aruz das Almas: Embrapa-CNPMF, 585 p.

Silva SO, Rocha SA, Alves EJ, Di Credico M, Passos AR (2000) Caracterização morfológica e avaliação de cultivares e híbridos de bananeira. Revista Brasileira de Fruticultura, 22 (2) 161-169.

Simmonds JH (1933) Banana Leaf Spot. Quensland: Department of Agriculture and Stock Division of Entomology and Plant Pathology.

Simmonds NW (1966) Bananas Diseases Longmans. 2: 366-408. 
Simmonds NW, Shepherd K (1955) The taxonomy and origin of the cultivated bananas. The Botany Journal of the Linnean Society of London, 55: 302-312.

Stergiopoulos I, de Wit PJGM (2009) Fungal effectors proteins. Annual Review of Phytopathology, 47: 233-69.

Stover RH (1970) Leaf spot of bananas caused by M. musicola: role of conidial in epidemiology. Phytopathology, 60: 856-860.

Stover RH (1978) Distribution and probable origin of Mycosphaerella fijiensis in southeast Asia. Tropical Agriculture, 55: 65-68.

Stover RH (1980) Sigatoka leaf spots of banana and plantains. Tropical Agriculture Research Services, 64: 750-756.

Stover RH, Simmons NW (1987) Bananas. Harlow, Essex: Longman Group UK Ltd.

Sunnucks P (2000) Efficient genetic markers for population biology. Tree, 15 (5): 199-203.

Thomma BPHJ, Nürnberger T, Joosten MHAJ (2011) Of PAMPs and Effectors: The Blurred PTI-ETI Dichotomy, The Plant Cell, 23: 4-15.

Turgeon BG (1998) Application of mating type gene technology to problems in fungal biology. Annual Review of Phytopathology, 36: 115-137.

Vázquez-Euán R, Grijalva-Arango R, Chi-Manzanero B, Tzec-Simá M, Islas-Flores I, Rodríguez-García C, Peraza-Echeverría L, James AC, Manzo-Sánchez G, CantoCanché B (2012) Direct colony polymerase chain reaction (PCR): An efficient 
technique to rapidly identify and distinguish Mycosphaerella fijiensis and Mycosphaerella musicola. African Journal of Biotechnology, 11(33): 8172-8180.

Waalwijk C, Mendes O, Verstappen ECP, De Waard MA, Kema GHJ (2002) Isolation and characterization of the mating-type idiomorphs from the wheat septoria leaf blotch fungus Mycosphaerella graminicola. Fungal Genetics and Biology, 35: $277-286$.

Wardlaw CW (1961) Leaf Spot. (Sigatoka Disease). Banana diseases: Including Plantains and Abaca, 11:314-341.

Wei Y, Mizzen CA, Cook RG, Gorovsky MA, Allis CD (1998) Phosphorylation of histone $\mathrm{H} 3$ at serine 10 is correlated with chromosome condensation during mitosis and meiosis in Tetrahymena. Proceedings of the National Academy of Sciences of the USA, Washington, 95 (13): 7480-7484.

Weir BS (1996) Genetic Data Analysis II: methods for discrete populations genetic data. Sunderland: Sinauer Associates, 445p.

White TJ, Bruns T, Lee S, Taylor J (1990) Amplification and direct sequencing of fungal ribosomal RNA genes for phylogenetics. In: PCR protocols: a guide to methods and applications. (MA Innis, DH Gelfand, JJ Sninsky, TJ White, eds): 282287.

Wirsel S, Horwitz B, Yamaguchi K, Yoder OC, Turgeon BG (1998) Single mating type specific genes and their 3'UTRs control mating and fertility in Cochliobolus heterostrophus. Molecular Genetics and Genomics, 259: 272-281.

Wong JEMM, Midtgaard SR, Gysel K, Thygesen MB, Serensen KK, Jensen KJ, Sougaard J, Thirup S, Blaise M (2015) An intermolecular binding mechanism 
involving multiple LysM domains mediates carbohydrate recognition by an endopeptidase. Acta Crystallography, 71: 592-605.

Wright S (1951) The genetical structure of populations. Annals of Eugenics, Quartely, 15: 395-420.

Yeh RC, Boyle TJB (1997) Population genetic analysis of co-dominant and dominant markers and quantitative traits. Belgian Journal of Botany, 129: 157.

Zapater MF, Duchemin M, Dussart JF, Coste D, Brottier P, Carlier J (2008) Microsatellite markers for the fungal banana pathogens Mycosphaerella fijiensis, Mycosphaerella musicola and Mycosphaerella eumusae. Molecular Ecology Resources, 8: 1121-1125.

Zhan J, Kema GHJ, Waalwijk C, McDonald BA (2002) Distribution of mating type alleles in the wheat pathogen Mycosphaerella graminicola over spatial scales from lesions to continents. Fungal Genetics and Biology, 36: 128-136.

Zhan J, Mundt CC, McDonald BA (2007) Sexual reproduction facilitates the adaptation of parasites to antagonistic host environments: Evidence from empirical study in the wheat-Mycosphaerella graminicola system. International Journal for Parasitology, 37: 861-870.

Zwiers LH, Waard MA (2001) Efficient Agrobacterium tumefaciens - mediated gene disruption in the phytopathogen Mycosphaerella graminicola. Current Genetics, 39: 388-393.

Zwiers LH, Stergiopoulos I, Gielkens M, Goodall SD, De Waard MA (2003) ABC transporters of the wheat pathogen Mycosphaerella graminicola function as protectants against biotic and xenobiotic toxic compounds. Molecular Genetics and 
Genomics, 269: 499-507. 


\section{Anexo 1. Artigos publicados}

1. Brito FSD, Fraaije B, Miller NGM (2015) Sigatoka disease complex of banana in Brazil: Management practices and future directions. Outlooks on Pest Management, 26 (2): 78-81.

2. Peixouto YS, Bragança CAD, Andrade WB, Ferreira CF, Haddad F, Oliveira SAS, Darosci Brito FS, Miller RNG, Amorim ED (2015) Estimation of genetic structure of a Mycosphaerella musicola population using inter-simple sequence repeat markers. Genetics and Molecular Research, 14 (3): 8046-8057. 